
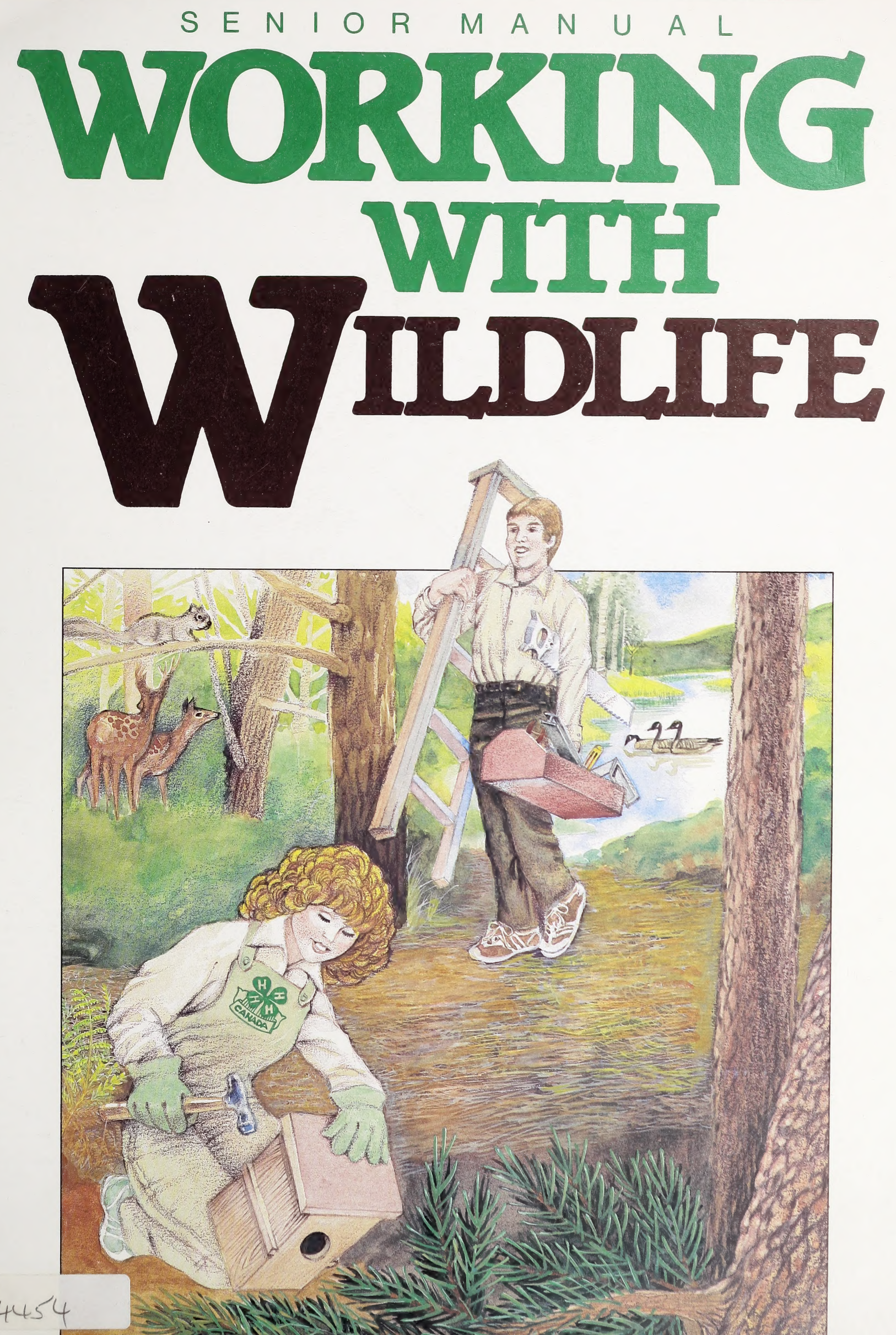

i) $N$ 
The Recreation, Parks and Wildlife Foundation of Alberta is pleased and proud to participate in the development of this 4 -H senior wildlife habitat manual. It is hoped that the objectives of the Foundation can be fostered through the efforts of the youth of Alberta for the greater benefit of all residents.

The objectives of the Foundation are - to develop or maintain recreational programs, facilities and services

- to develop or maintain parks;

- to manage and conserve fish and wildlife.

For further information about the Foundation, its work, and how you can participate and assist, contact

Chuck Moser

Executive Director

Recreation, Parks and Wildlife

Foundation

6th Floor, Pacific Plaza

10909 Jasper Avenue

Edmonton, Alberta

T5J 3M9

Telephone: (403) 420-1345 


\section{4-H MOTTO}

Learn to do by doing.

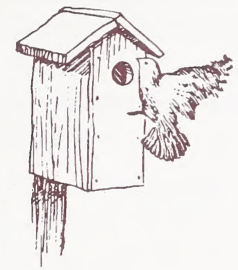

\section{4-H PLEDGE}

I pledge

My HEAD to clearer thinking,

My HEAR'T to greater loyalty,

My HANDS to larger service,

My HEALTH to better living,

For my club, my community and my country.

\section{4-H GRACE}

(Tune to Auld Lang Syne)

We thank thee, Lord, for blessings great

On this, our own fair land.

Teach us to serve thee joyfully,

With head, heart, health and hand.

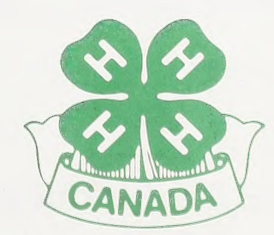




\section{Table of Contents}

Page

2 Introduction

2 Other Wildlife Projects

Achievement Day

Individual Project

4. Lesson 1

Managing Alberta's Wildlife Resources

7 Lesson 2

Habitat Management Tools

1 Lesson 3

1 Wetland Habitat

14 Lesson 4

14 Enhancing and Creating Wetlands

$16 \begin{aligned} & \text { Lesson } 5 \\ & \text { Woodland Habitat }\end{aligned}$

10 Lesson 6

$20 \begin{aligned} & \text { Lesson } 7 \\ & \text { Protecting and Enhancing Croplands and Irrigated Crops }\end{aligned}$

$22 \quad \begin{aligned} & \text { Lesson } 8 \\ & \text { Rangelands }\end{aligned}$

26 Lesson 9

Protecting and Enhancing Rangeland Habitat

2 Lesson 10

Wildlife In Your Backyard

20 Answer Section

32 Glossary

23 Fish and willife Offices

24 Ducks Unlimited Offices

25 Metric Conversion Table 


\section{Introduction}

Welcome to the 4-H senior Working with Wildlife project. In this project, you learn much about improving wildlife habitat on your land and land near you. It is called Working with Wildlife because you work with wildlife by completing many habitat improvement projects. Wildlife are important natural resources and they depend on man to protect, enhance and develop their living spaces. If they do not get this protection and help, many species will disappear.

This project book contains fact sheets for each of the ten lessons in a pocket at the back of the book. Read the fact sheet relating to the lesson and complete the lesson's activities. Since many of the activities must be completed outdoors, you may have to rearrange their order depending on weather and season. Some activities can be started or planned inside and carried out in good weather (for example, ordering trees for shelterbelts or building bird houses and feeders). You may not see results of your activities for as long as a year after you complete them. But be patient! Wildlife will eventually show their appreciation for your efforts.

A glossary at the back explains terms you might not know. Also included is a chart in the back pocket on how to control wildlife species which become nuisances. The project aims to show how man and wildlife can live together, benefitting rather than harming each other.

The project was produced and funded in co-operation with the 4- $\mathrm{H}$ Branch of Alberta Agriculture, the Fish and Wildlife Division of Alberta Energy and Natural Resources, the Canadian Wildlife Service and the Recreation, Parks and Wildlife Foundation of Alberta.

\section{Other Wildlife Projects}

This project is the second in the 4-H habitat series. You probably have already completed the junior Living with Wildlife project and may want to refer to it during this project to refresh your memory on some of the wildlife terms and concepts.

In the 4-H Pheasant Project, you can raise day-old pheasant chicks for 12 to 14 weeks, when they are released to the wild. The Brooks Wildlife Centre supplies chicks and feed to all members who meet basic requirements. The members also must be responsible and sincere in their interest in pheasants.

\section{Achievement Day}

At the end of this project, members hold an Achievement Day where they tour each member's land. Each member gives a short talk on wildlife habitat. The member should point out examples of good and bad habitat, and how habitat can be improved. This project book and all photographs and displays should be on hand for members to view.

\section{Individual Project}

If you complete this project on your own and want to know how you did, send it to your local fish and wildlife office. Addresses and phone numbers are listed at the back of the book. Staff will be glad to comment on your efforts and return your work. Do not hesitate to contact your local office if you have any questions or problems regarding outdoor project activities. Anyone who submits a project book for evaluation, whether doing the project individually or in a group, will receive a set of four habitat posters. 


\section{Lesson 1}

\section{Managing Allberta's Wildllife Resources}

\section{Activity 1}

Read Fact Sheet 1. Below are two photographs of Ducks Unlimited Canada projects. Beside each, describe what problem you think the project attempts to solve, what caused the problem and how wildlife might benefit from the project. Check your answers in the Answer Section.
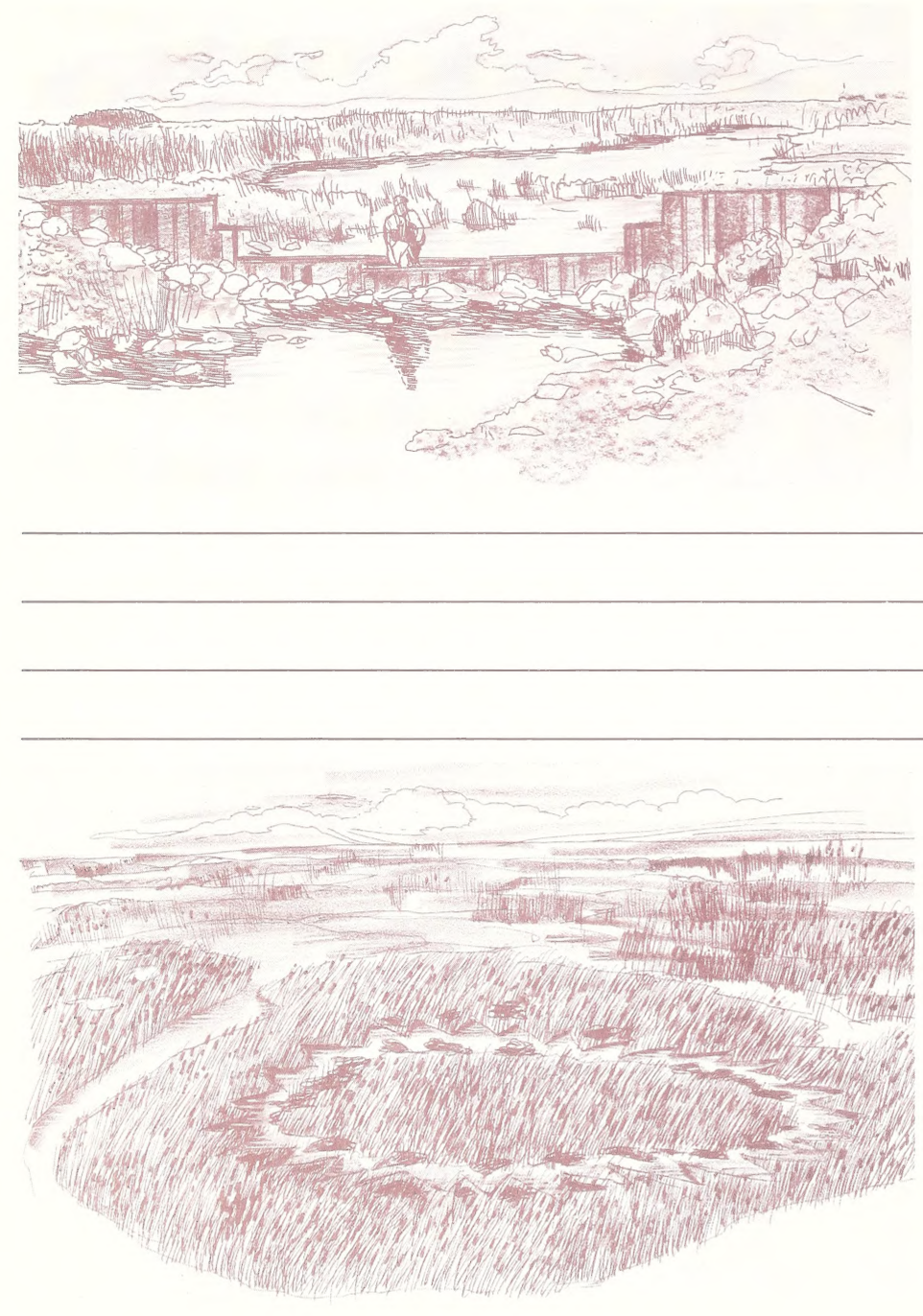


\section{Activity 2}

Visit a habitat improvement area near you (Ducks Unlimited or Buck for Wildlife). Be sure to contact the appropriate office (local Ducks Unlimited or Fish and Wildlife Office) before you go. If possible, ask a representative to go with you to explain the project. What habitat problem does the project attempt to solve and how was the problem caused? Is it successful? Were there any signs of wildlife at or near the project. Discuss these questions with the representative, your leader and other members. Write a summary below.

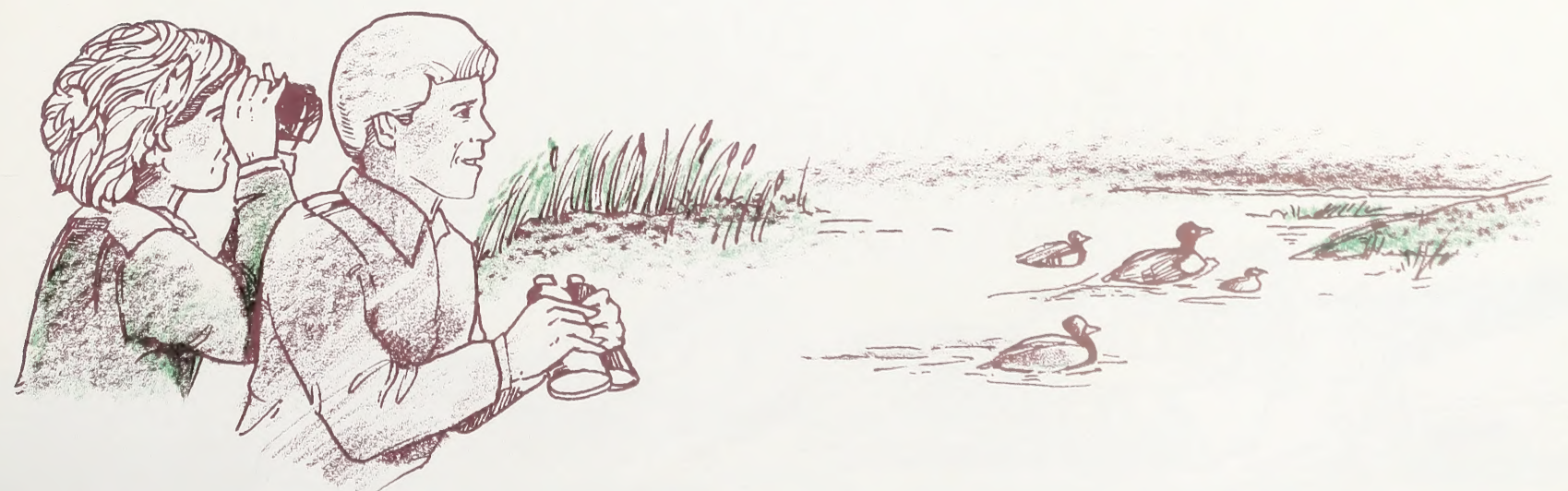




\section{Activity 3}

Draw a map of your area (about 25 square kilometres around your home). Mark in colored pencil any areas where wildlife habitat has been cleared in the last five years to make way for roads, houses, industries or crops.

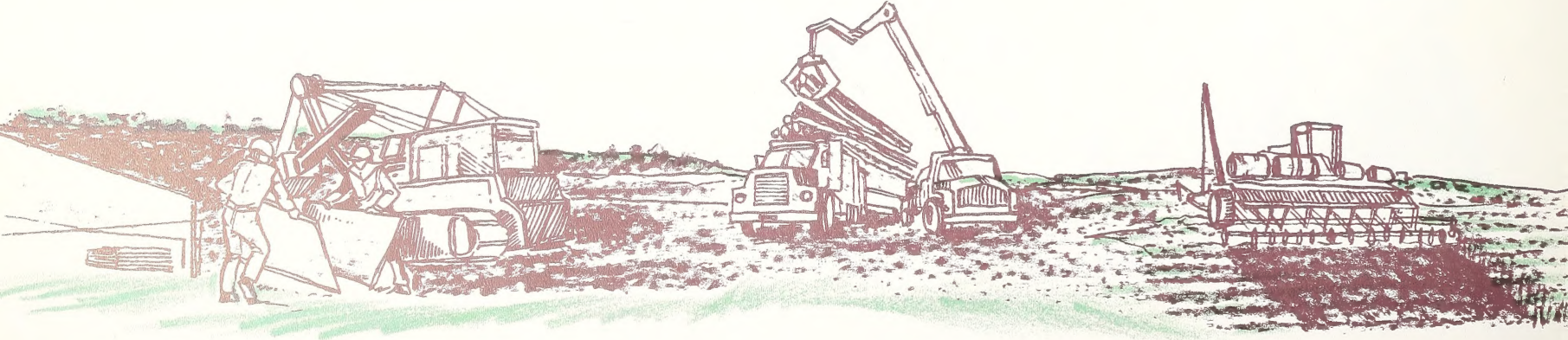




\section{Lesson 2}

\section{Habitat Management Tools}

\section{Activity 1}

Read Fact Sheet 2. In the grid below, can you find some of the groups in the list that help wildlife. They are written up, down, forward, backward and diagonally. Check your answers in the Answer Section. Can you think of others that help wildlife in your area.

Canadian Wildlife Service

Ducks Unlimited Canada

Fish and Wildlife Division

Four-H'ers

Alberta Naturalists
Fish and Game Associations

Canadian Wildlife Federation

Canadian Nature Federation

Landowners

\begin{tabular}{|c|c|c|c|c|c|c|c|c|c|c|c|c|c|c|c|c|c|c|}
\hline & & & & & & & & & & & & & & & & & & \\
\hline & & Z & & V & & & & & & & & & & & & & & \\
\hline & & $\mathrm{K}$ & & $\mathrm{N}$ & & & & & & & & & & & & & $V$ & \\
\hline & & $\mathrm{G}$ & & W & & & & & & & & & & & & & $X$ & \\
\hline & $W$ & $\mathrm{~N}$ & $C$ & & & & & & & & & & & & $\underline{1}$ & & $A$ & $B$ \\
\hline & $\Lambda$ & $K$ & C & $G$ & & & & & & & & & & & B & & 0 & $F$ \\
\hline & 1 & & & $S$ & & & & & & 1 & & & & & C & -1 & $E$ & $E$ \\
\hline & & $\mathrm{R}$ & $\mathrm{F}$ & $F$ & & & & & & & & & & 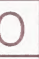 & - & & Q & $R$ \\
\hline & D & A & & $\mathrm{P}$ & & & & & & & & & & J & L & & & $\bar{U}$ \\
\hline & $A$ & 1 & $U$ & $N$ & & & & & & E & 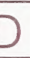 & & & $R$ & 5 & & & $\mathrm{~T}$ \\
\hline & $\bar{\Lambda}$ & 1 & $\underline{S}$ & $Z$ & & & & & & $S$ & & & & & & & $M$ & $A$ \\
\hline & $\Delta$ & $P$ & $\mathrm{~K}$ & $\mathrm{~T}$ & $x$ & & $\Lambda$ & & & & & & & & & & K & $N$ \\
\hline-1 & & $\mathrm{~T}$ & $C$ & $\mathrm{~V}$ & & & & & & & & & & & & & $Q$ & $N$ \\
\hline$A$ & $\Lambda$ & $\bar{N}$ & $U$ & C & & & & & & & & & & & & & A & $E$ \\
\hline$\sqrt{V}$ & & $\mathrm{G}$ & D & $Y$ & & $T$ & & & & & & & & & & & $U$ & $Z$ \\
\hline & $P$ & $\mathrm{H}$ & $Z$ & $\mathrm{~V}$ & & & & & & & & N & & & D & & $S$ & $S$ \\
\hline & & $\underline{X}$ & $k$ & $\mathrm{R}$ & & & & & & & & & & & & & $\mathrm{Ml}$ & R \\
\hline & & $D$ & $\mathrm{~N}$ & $\mathrm{~N}$ & & & & & & & & & & & & & B & $\mathrm{E}$ \\
\hline & & G & & $N$ & & 0 & & & & & & & & & & & $\mathrm{R}$ & $\mathrm{H}$ \\
\hline & & & & & & & & & & & & & & & & & & \\
\hline
\end{tabular}




\section{Activity 2}

Read the newspapers or listen to the news on radio or television for one month. Cut out all articles about wildlife and keep them in the pocket at the back of this book. If the item was on radio or television write a brief summary. Give a two-minute talk on one of the news items describing what it was about, the source (person quoted) and what your views on the problem outlined. If any of your news items involve changes in land use, describe what impact the change will have on wildlife habitat. If the news item asks for public input, jot down your views and send them to the address listed. Describe your talk below and any action you took.

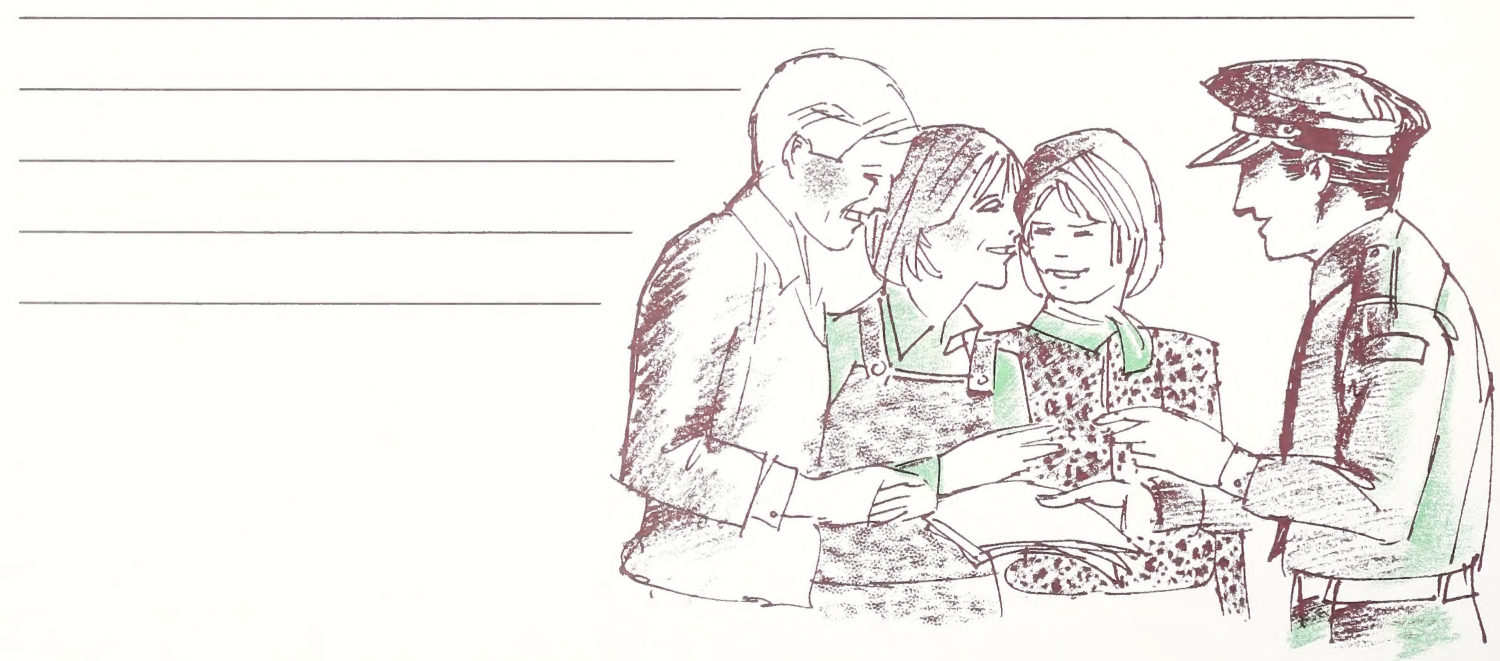




\section{Activity 3}

Photograph or draw two examples of good wildlife habitat near your home
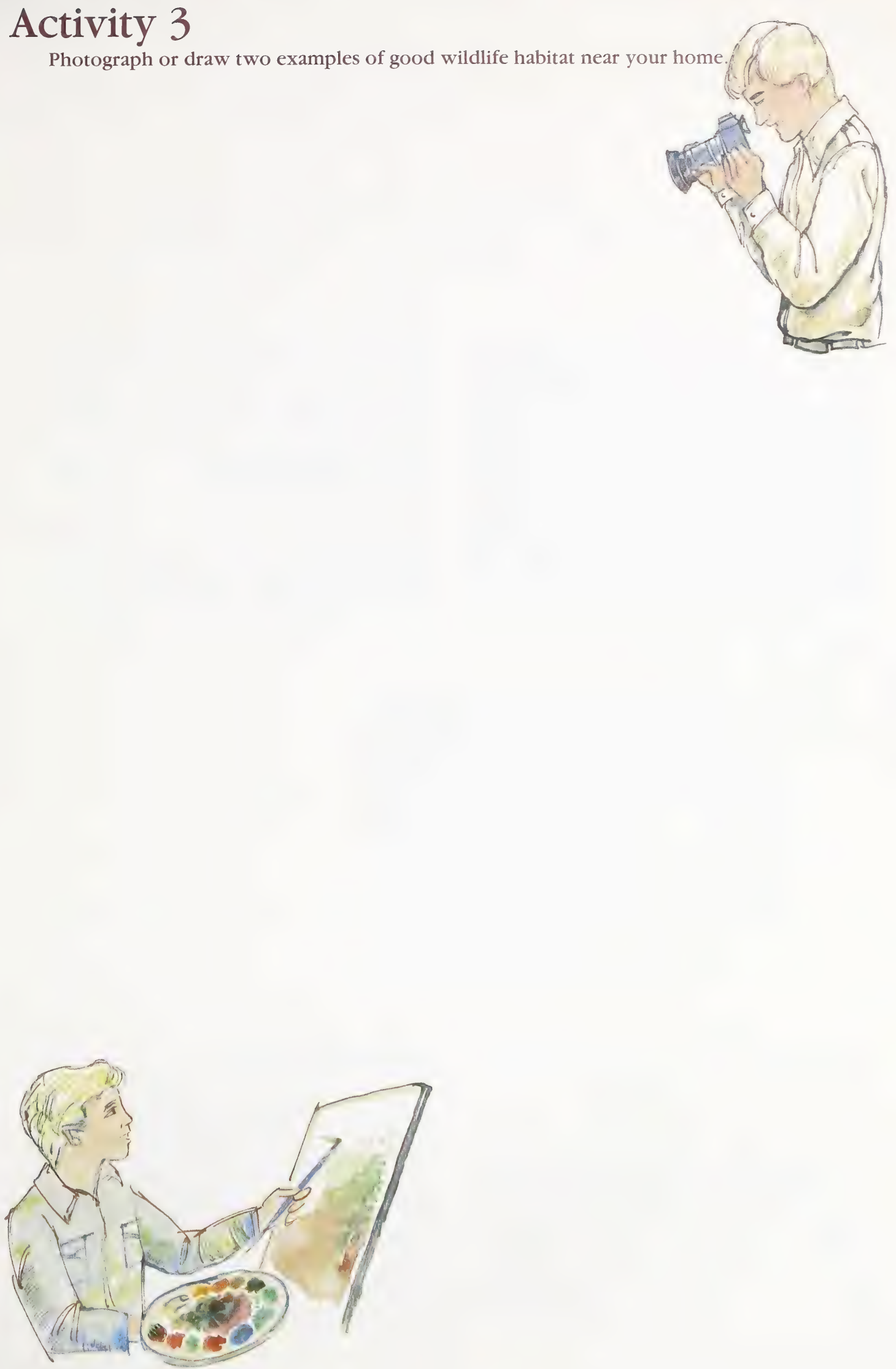


\section{Lesson 3}

Wetland Habitat

\section{Activity 1}

Read Fact Sheet 3. Can you identify each of the five major types of wetlands below. Check your answers in the Answer Section.

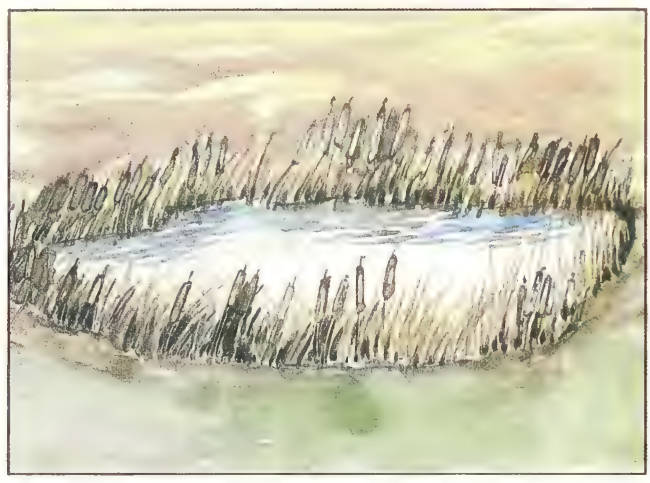

A

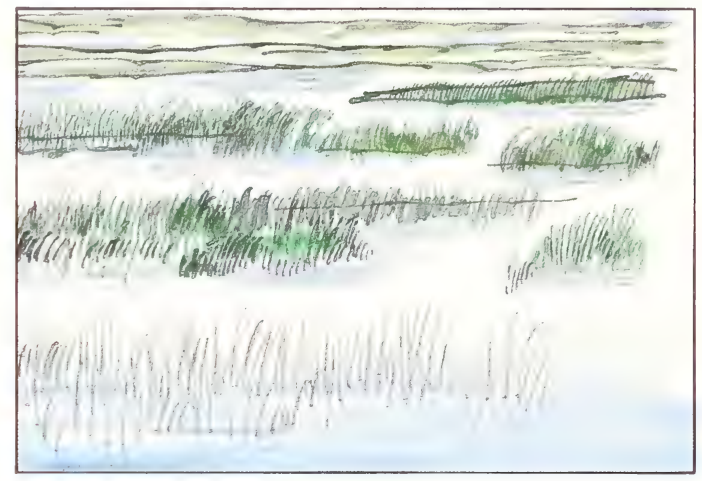

B

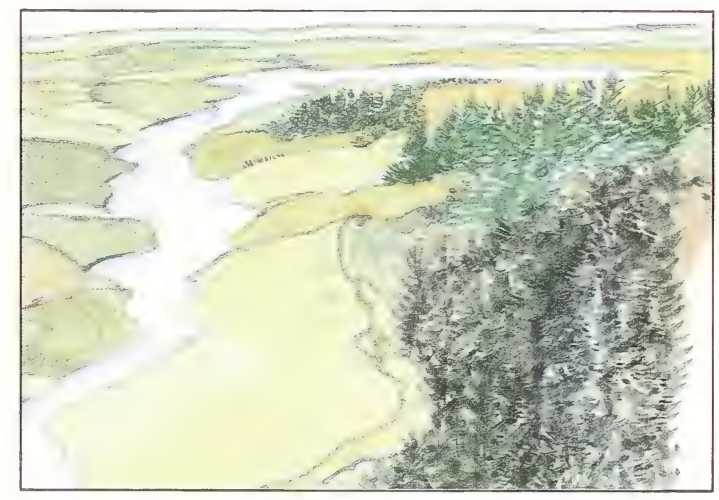

C
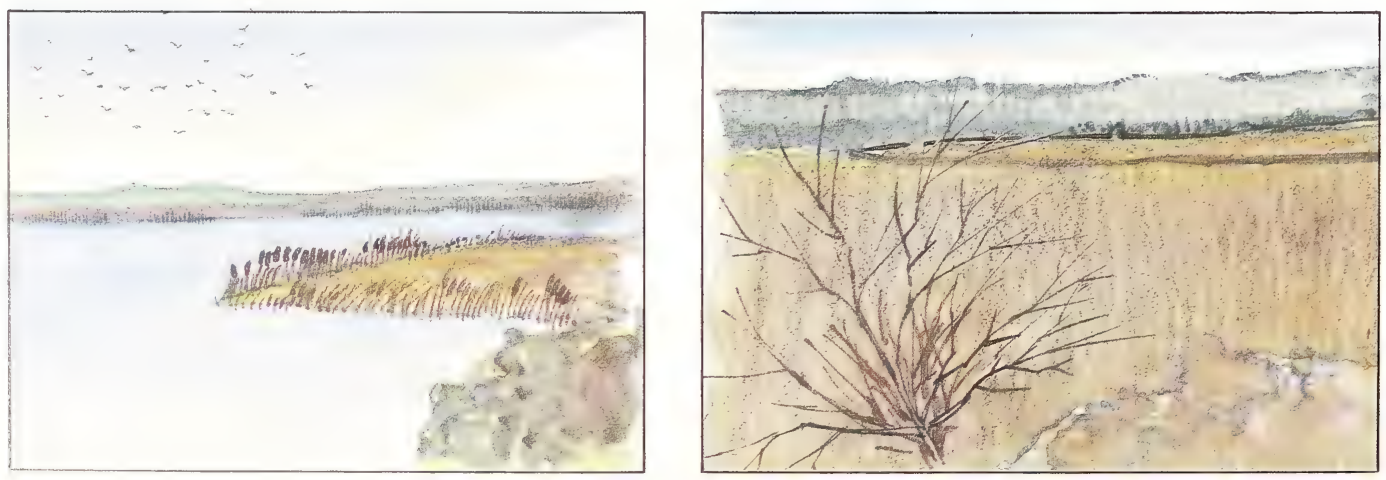

i)

E 


\section{Activity 2}

Make your own wetland.

Materials needed: four large jars or plastic containers; four kinds of soil (sand, sandy loam, clay or clay loam); organic material; gravel; red food coloring; a quart of dry sand.

a) Place two centimetres of gravel in the bottom of each jar. Add different soils to each jar until half full. Add two centimetres of organic material.

b) Add tap water in 50 millilitre amounts to each container. Wait two minutes between additions. Which soil drains most quickly? Why? Which soil type absorbs the most water before showing puddles?

c) These containers now satisfy one of the conditions for being a wetland. What other conditions are required for these containers to be real wetlands? Check your answer in the Answer Section. 
d) Man's activities sometimes cause erosion which results in too much sand building up in wetland areas. Pour sand into one of the wetland containers. What does this do to the wetland? Can it be reversed? Check your answers in the Answer Section.

e) Pretend the food coloring is a poisonous chemical. Place several drops of food coloring at one edge of the container. What happens? How does poison act in a real wetland? Check your answers in the Answer Section. 


\section{Activity 3}

Can you unscramble the plants and animals listed below that you might find in wetland areas? Check your answers in the Answer Section.

$\begin{array}{ll}\text { soms } & \\ \text { behrs } & \\ \text { desseg } & \\ \text { ubleshurs } & \\ \text { islactat } & \\ \text { everab } & \\ \text { sucdk } & \\ \text { rheosn } & \\ \text { plisance } & \\ \text { drobssing } & \end{array}$

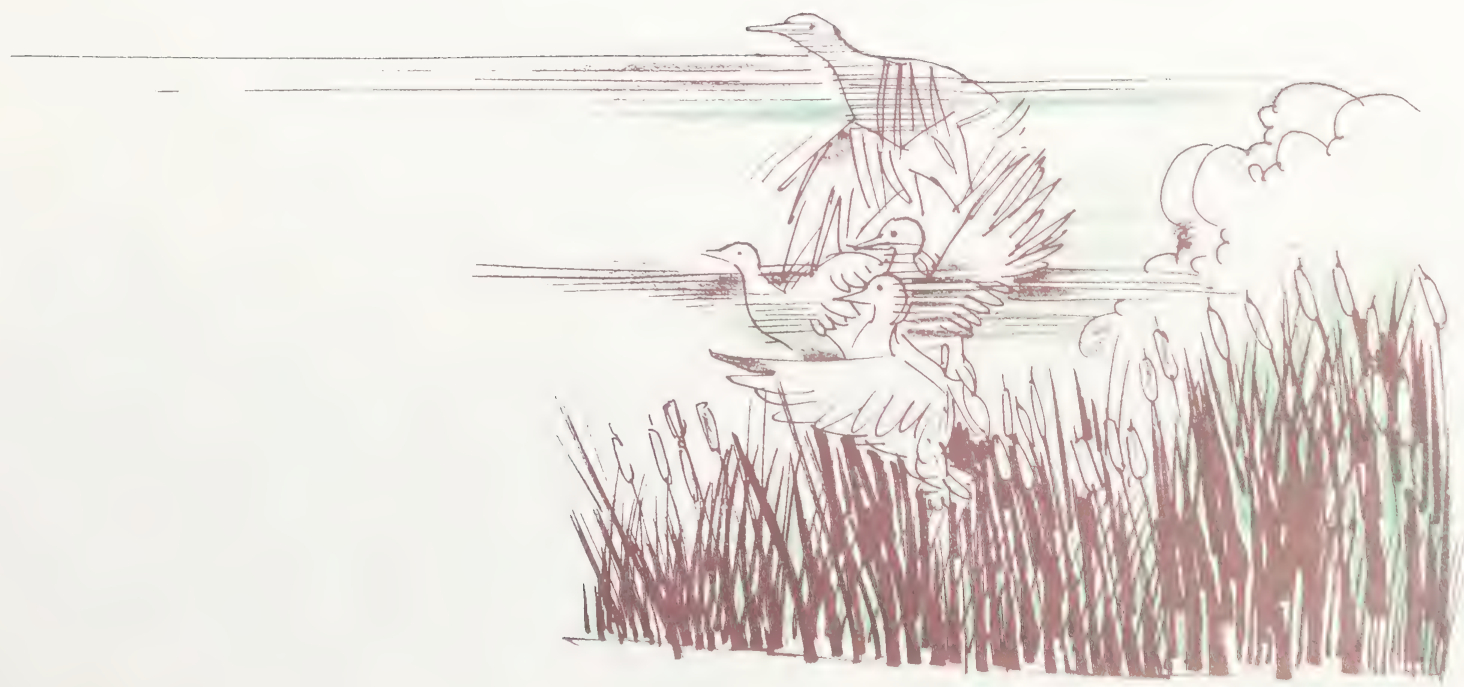




\section{Lesson 4}

\section{Enhancing And Creating Wetlands}

\section{Activity 1}

Read Fact Sheet 4. Below is a map of a wetland area. With colored pencil, mark areas which make good wildlife habitat. In another color, show areas of poor habitat. Using a third color, add improvements to increase the value of the area for wildlife habitat. Be sure to include a key explaining the colors you used. Check the Answer Section for ideas.

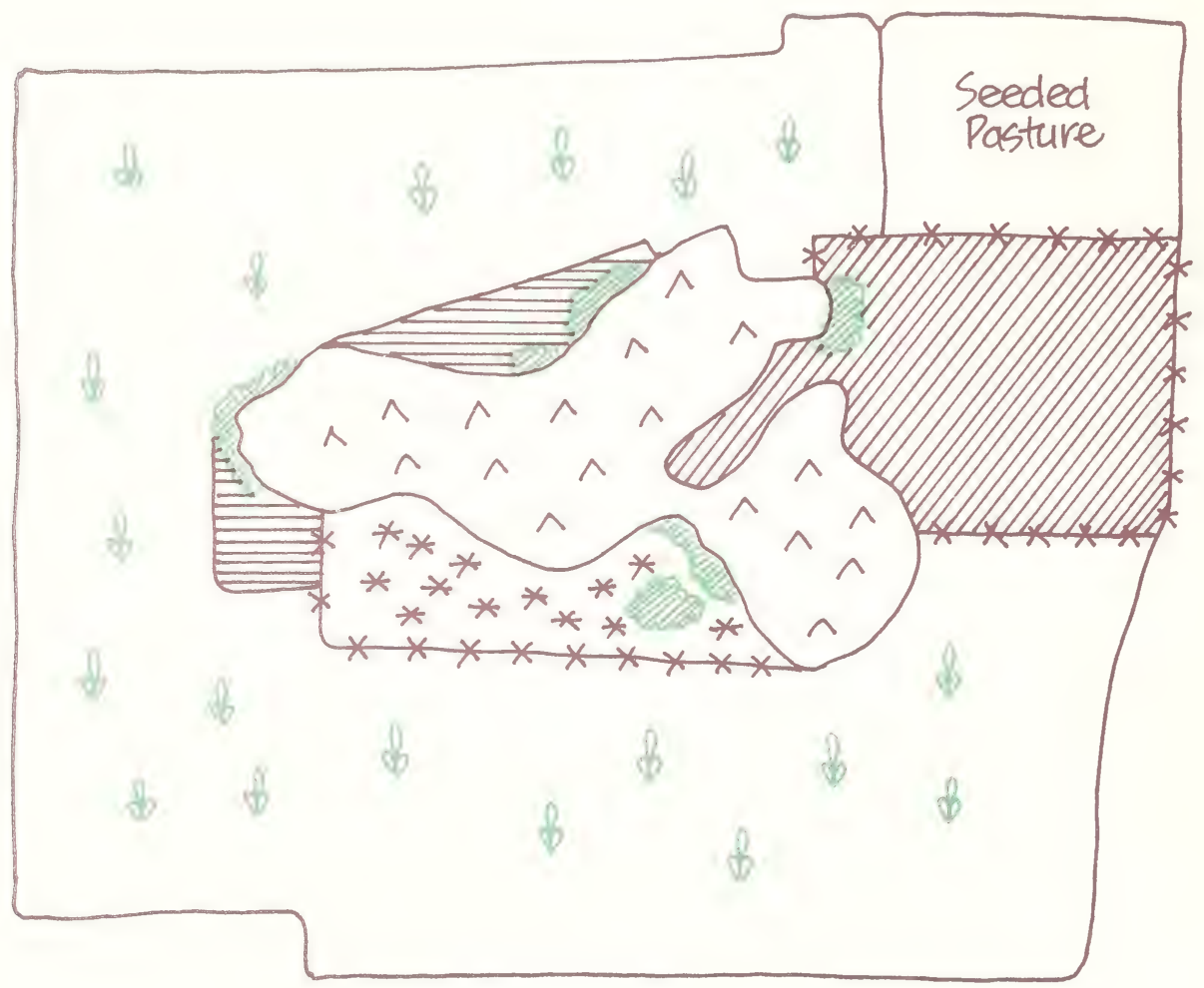

Water $\wedge$ -

Cropland \&

Hayland

Overarazed Native Pasture WIIA

Ungrazed Native Dasture * *

Trees

Fences $-* x *$ 


\section{Activity 2}

Obtain permission to carry out some of the improvements you mapped in the previous activity. Suggestions include fencing, creating brushpiles, nest boxes, baskets, cones, round bales, grass and legume seeding, tree and shrub planting, and creating open water. Watch your improved wetland carefully and note any changes in wildlife over the next year. Write your observations below along with a description of improvements and costs. If you are not able to carry out any improvements, describe something you would like to do. Include costs.

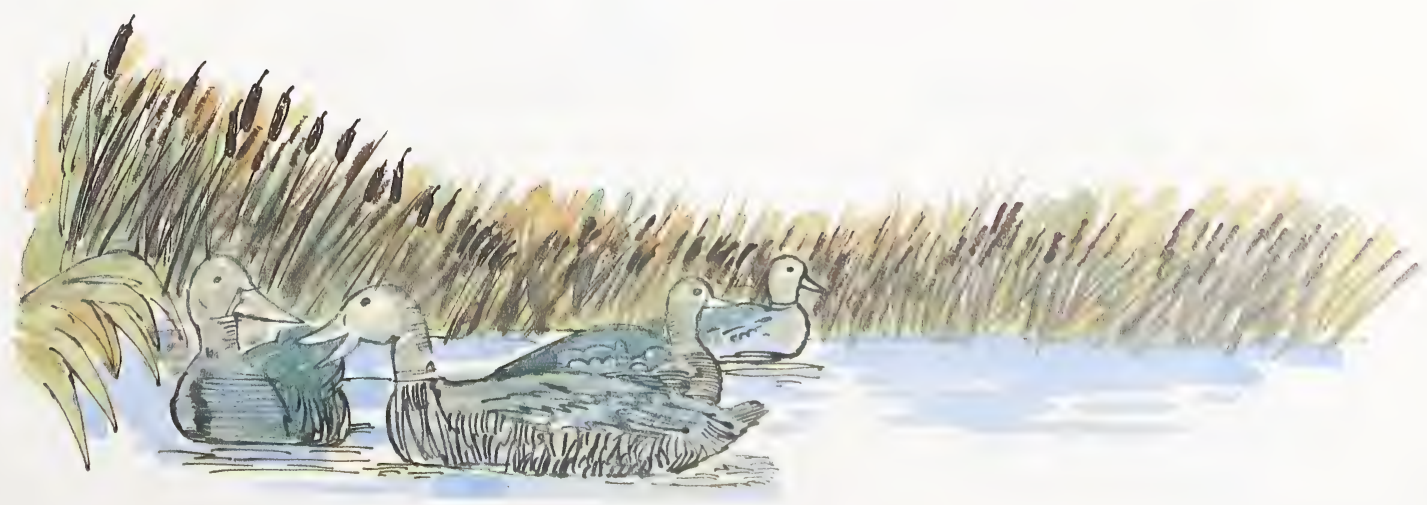




\section{Lesson 5

\section{Activity 1}

Read Fact Sheet 5. Go on a wildlife "hunt". Don't forget your notebook and binoculars! You can also take along a camera and tape recorder. Make a large map of the areas you studied and mount it on cardboard. Show different habitat types - wetlands, woodlands, fields and cultivated areas. Mark all spots where you noted signs of wildlife (tracks, bits of fur and feathers, sounds, droppings, signs of eating and so on).

Make a display including your map and all wildlife evidence. You can even make plaster casts of animal tracks using the method below. The best casts are made from deep imprints in damp soil or mud. Display your project in the community where many people can see it (for example in a school, community centre or store window).

a) Make a cardboard frame. Rub vaseline on the inside. Place the frame around the track.

b) Mix plaster powder with water to a thick, creamy consistency. Pour the mixture into the frame.

c) Let it set for 20 minutes. Remove the frame and brush the mould clean.

d) Apply vaseline to the inside of the frame. Place the mould inside.

e) Mix new plaster and pour it into the mould. Allow it to set for about 20 minutes.

f) Remove the frame. Brush the mould. Dry it well and rub it gently with sandpaper.

g) Scratch the name of the animal into the cast below the track.

A.
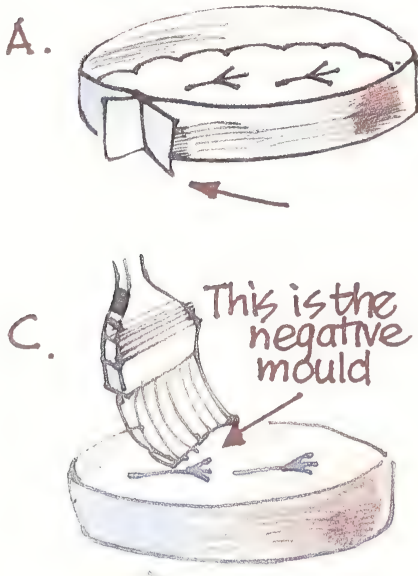

E.

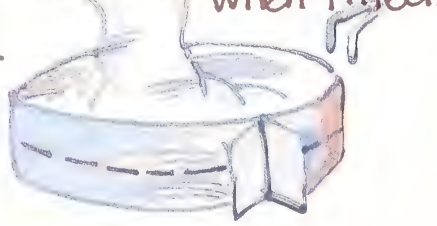

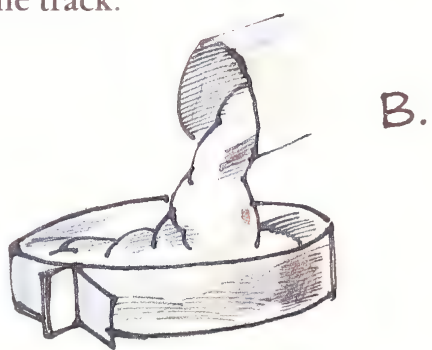

Besure to remove all particles.

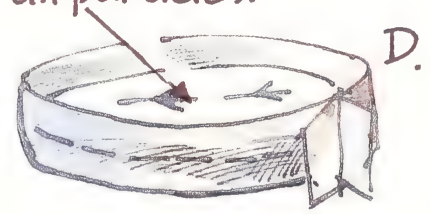

This is the positive mould.

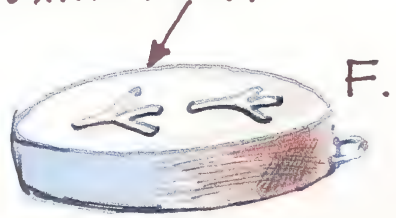




\section{Activity 2}

This activity is optional. Visit a beaver pond near you. Did you see signs of plant succession? If so, draw a cross-section below of successional stages, identifying plants and trees. List other plants and animals you saw, below the diagram. 


\section{Lesson 6

\section{Activity 1}

Read Fact Sheet 6. Build and install a nest box for bluebirds or other cavity nesting birds. (See Fact Sheet 10 for instructions). Fill in the following record.

a) Species of bird for which the house was built

b) Materials used

c) Costs

d) Date the house was put up

e) Describe the location of the house

f) Why was the location chosen?

g) What kind of bird is using the house?

h) Notes on nest building, hatching, feeding, young, etc.

i) Date nest box cleaned

j) Photo or drawing of house. 


\section{Activity 2}

What can you do to improve a woodland for wildlife? Check the Answer Section for ideas.

\section{Activity 3}

Pick one improvement mentioned in Activity 2 and carry it out. Describe your project below including costs and any differences noted in wildlife populations and species. If you are not able to carry out an improvement, describe a project you would like to do. Include estimates of costs. 


\section{Lesson 7 \\ Protecting and Enhancing Croplands and Irrigated Lands}

\section{Activity 1}

Read Fact Sheet 7. Map a cultivated field near you, complete with wetlands, woodlands and pasturelands. In another color, show what you would do to improve the area for wildlife habitat. Check the Answer Section for ideas.

\section{Activity 2}

Leave a strip of grain standing near wildlife cover and document wildlife species that use this food source during the winter. 


\section{Activity 3}

Design a shelterbelt below or show how you would improve an existing shelterbelt.

Describe the types of trees, shrubs and plants in your design. If possible, plant your shelterbelt or carry out your improvements in the spring. Contact your district agriculturalist for information on ordering trees free of charge.

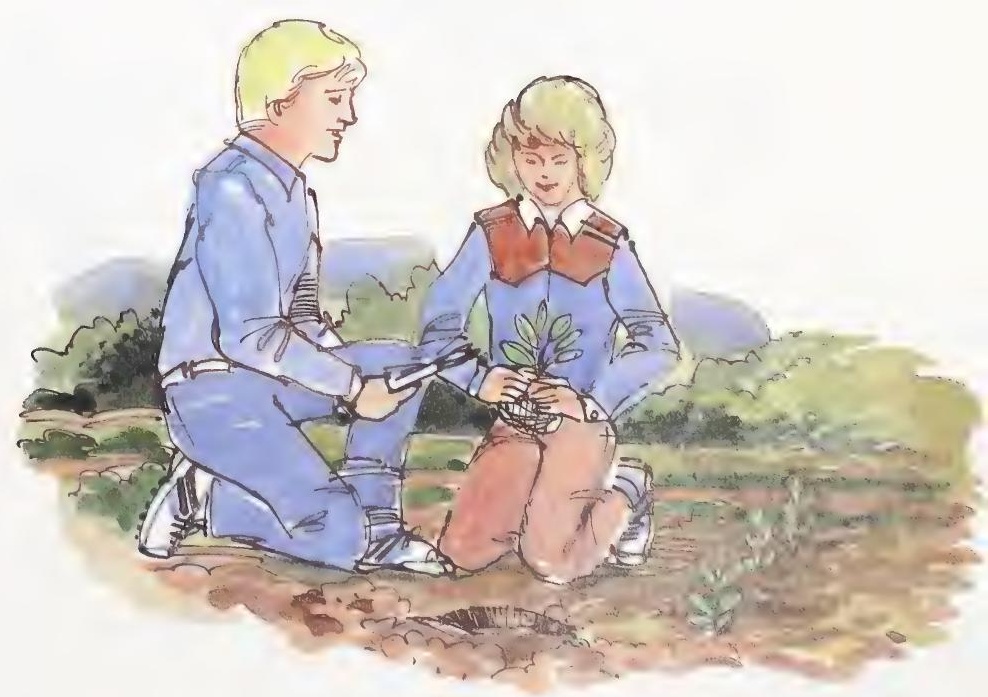




\section{Lesson 8}

Rangelands

\section{Activity 1}

Read Fact Sheet 8 . Visit a native rangeland near you. Which of the four rangeland types was it? Circle the plants you saw and put an asterisk beside the ones which make best grazing Draw a square around wildlife species you think might use this rangeland habitat. Check the Answer Section for grazing plants and rangeland wildlife species.

Rangeland type

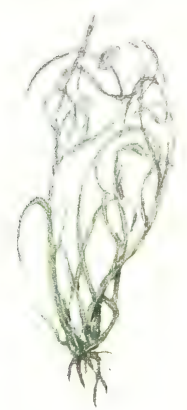
needle and
thread

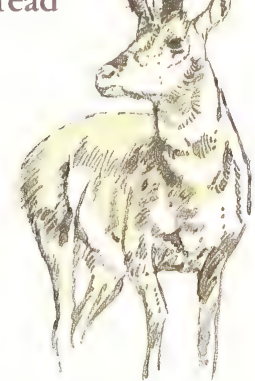

pronghorn antelope

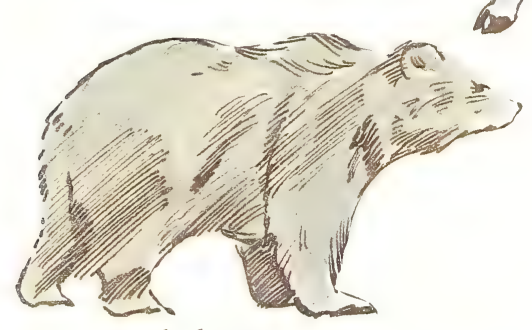

grizzly bear

dandelion
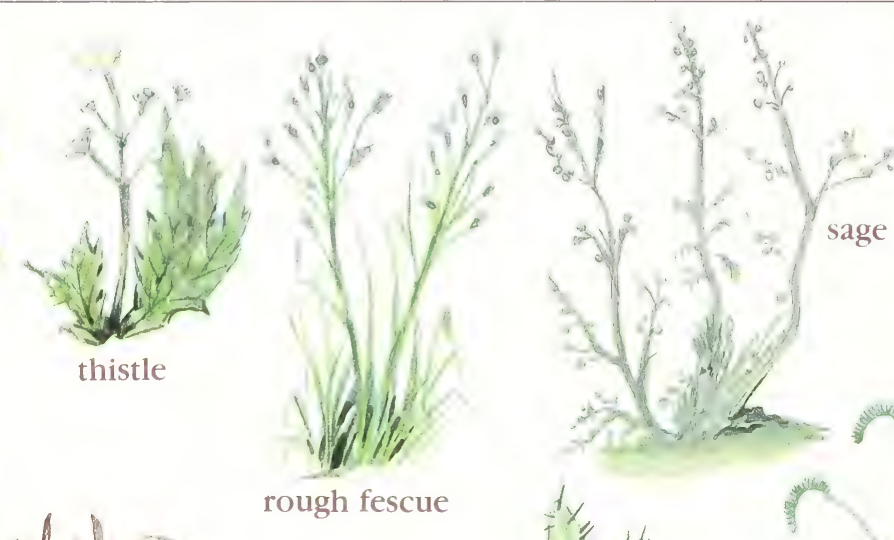

fon
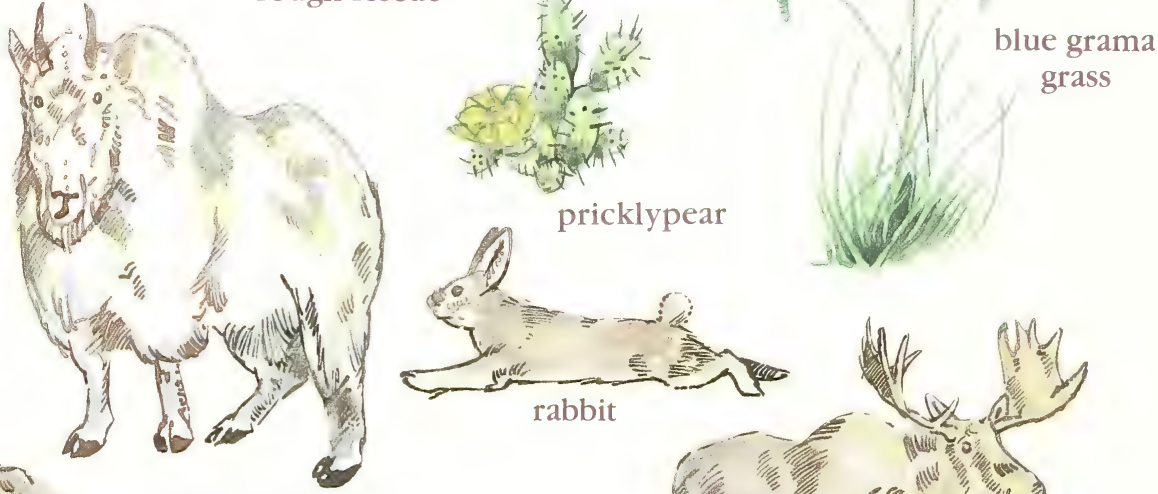

mountain goat
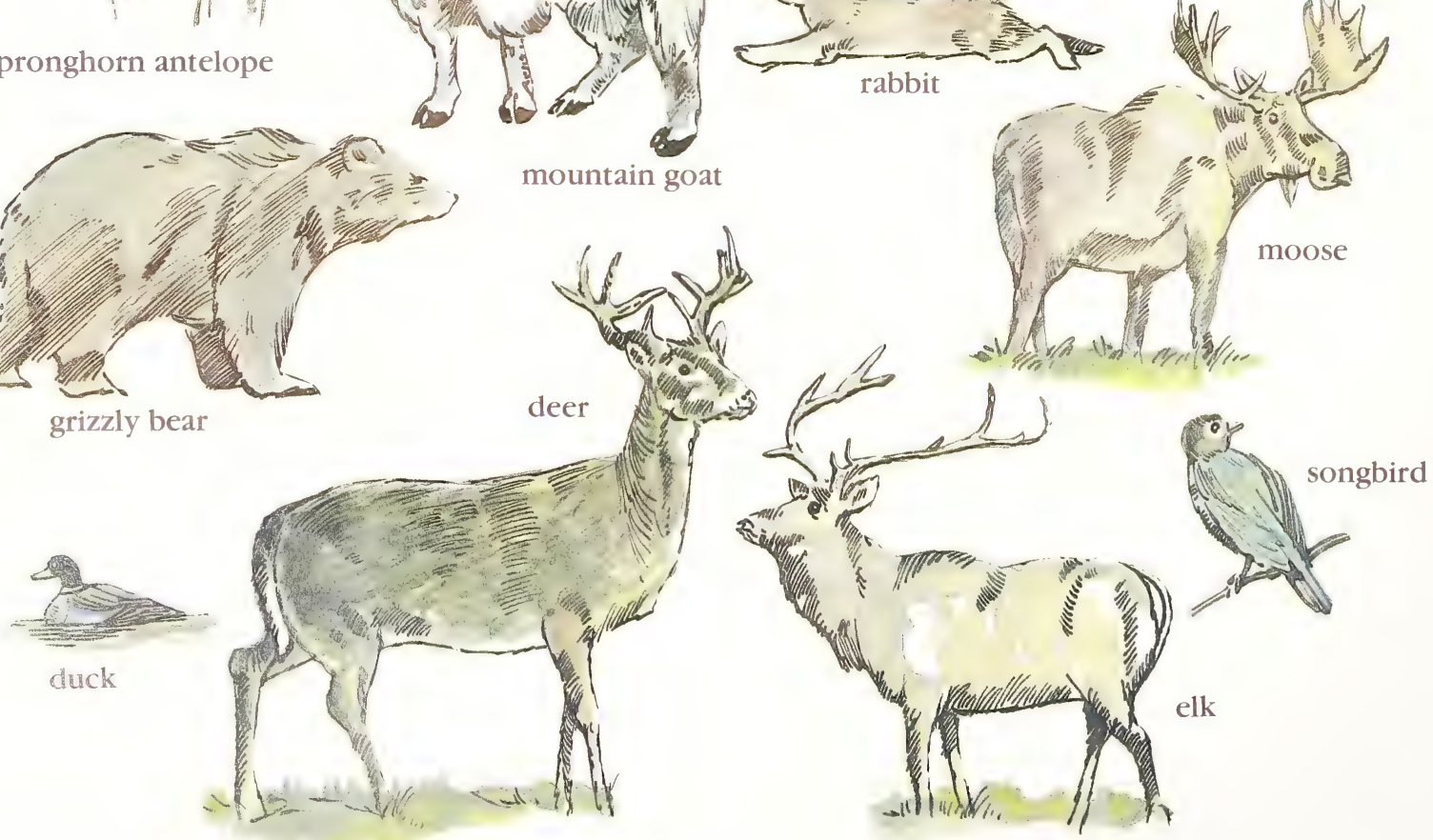


\section{Activity 2}

Gather samples of as many different range plants as you can find. Press and mount them below and on the next page. Label each plant. Place cardboard on each side of the page to protect your plants. If you need more space, mount additional plants on cardboard and keep them in the pocket at the back of this book.

\section{Tips for Pressing and Mounting Plants}

1. For flowering plants and weeds, press the entire plant if possible, including flower and fruit. Collect two or more specimens and mount the best one.

2. Place specimens between sheets of newspaper for pressing. Use heavy cardboard or plywood for the backs to keep the newspaper flat. Specimens collected in midsummer are easier to press and more typical than those collected earlier. Press for two or three weeks in a warm, dry place. Change the newspaper sheets every two or three days to prevent leaf discoloration. Press one leaf of each specimen with the underside up.

3. When mounting specimens, use transparent tape cut into small, thin strips. Be sure to fasten them well. 
Rangeland Plants 


\section{Activity 3}

Pick a wetland, woodland or odd area and fence it to keep out livestock. If the area is a livestock watering hole, provide livestock with limited access. Describe the area fenced, plant condition, cost and labour. Note any changes in plants or wildlife use after two months. If you are unable to carry out the activity, describe an area you would like to fence. Include estimates of costs.

\section{Area Fenced}

Plant Condition:

\section{Cost:}

Labour (Number of Hours):

Changes After Two Months: 


\section{Lesson 9}

Protecting and Enhancing Rangeland Habitat

\section{Activity 1}

Read Fact Sheet 9. Below is a map of rangeland. Draw in fencing required to use one of three grazing rotational systems described in the fact sheet. What other enhancements and improvements can be added (watering areas, salt, etc.) to improve range management. Check the Answer Section for ideas.

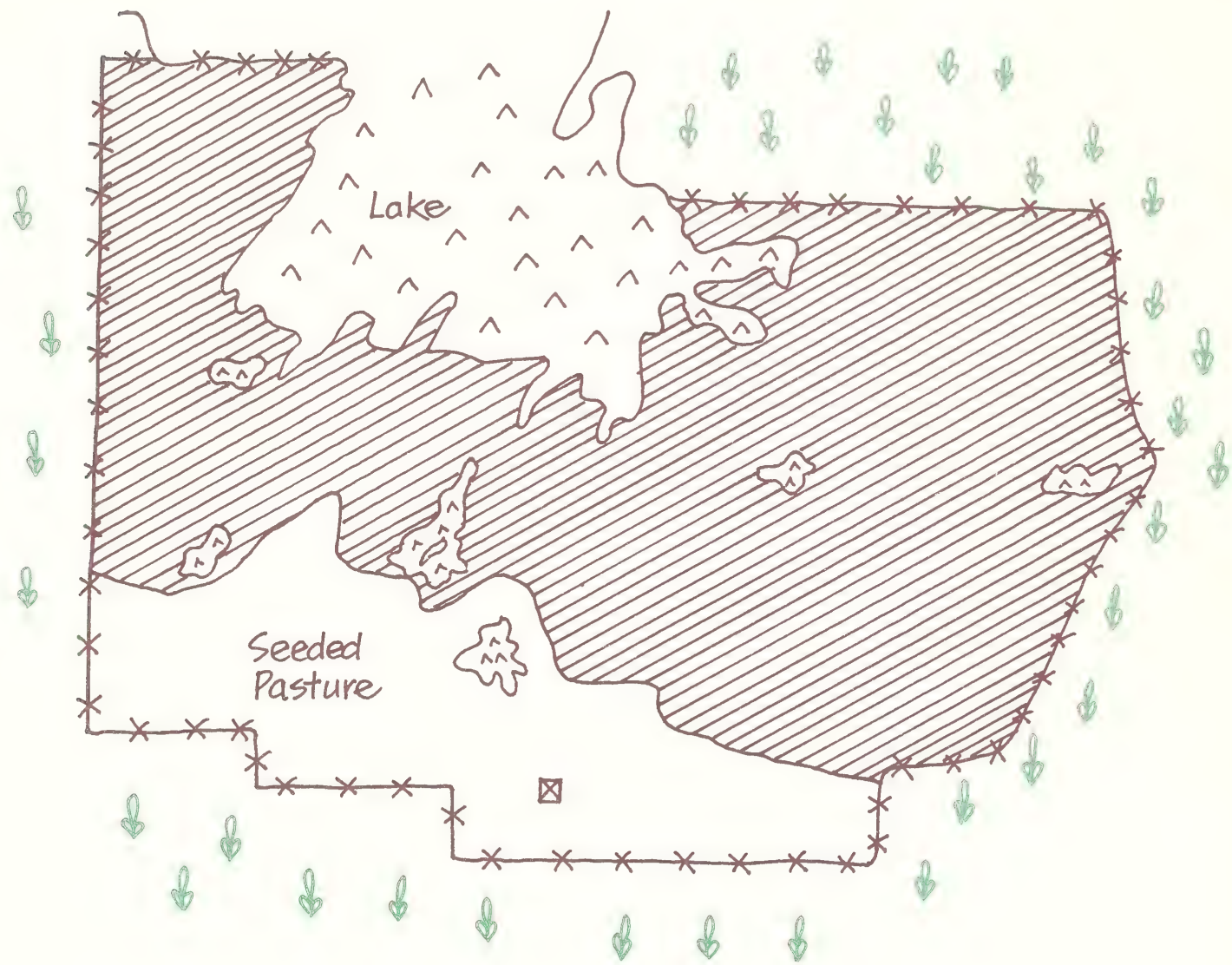

(Area covers approximately 2,000 acres or 800 hectares

Fence $-x * x$

Water $\wedge \wedge$

Cultivated cereal Crops \&

Salt block $\nabla$

Overgrazed Native Range 


\section{Activity 2}

Describe why you chose the grazing system you did in Activity 1 and how it will benefit wildlife. 


\section{Lesson 10 \\ Wildlife in your Backyard}

\section{Activity 1}

Read Fact Sheet 10. Map your yard below. Include the house, garage, barn, any out buildings, patios, fences, sloping and shaded areas and water sources. In another color, draw in improvements listed if they are not already there.

raspberry, chokecherry, buffalo berry bushes

rose hedge

alder, birch, pine, spruce and mountain ash trees

honeysuckles and elderberries

bird feeder

nest box

vegetable garden

flower beds (identify types of flowers)

water source.

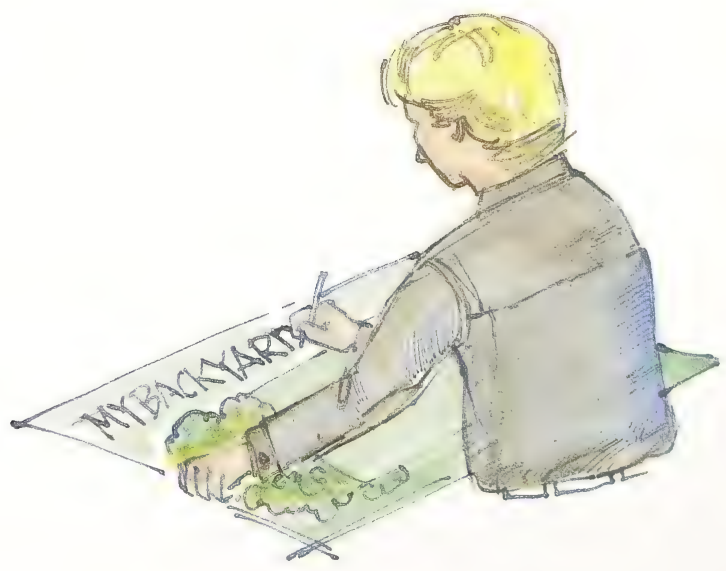




\section{Activity 2}

Make a bird house or bird feeder following the plans in Fact Sheet 10 or any other plan you would like to try. Fill in the following record.

a) Material from which the house or feeder was made.

b) Date installed.

c) Describe the location.

d) Why was the location chosen?

e) What kind of bird(s) use(s) the house or feeder?

f) Picture or drawing of the bird house or feeder. 


\section{Answer Section}

Lesson 1

1. The Eye Hill Creek Project, $20 \mathrm{~km}$ south of Provost, is a water-reservoir created to retain water for farm stock and waterfowl. Water reservoirs are common in Southern Alberta where lack of rainfall causes water shortages. For wildlife, lack of stable water sources is a serious limiting factor. Many species cannot survive in these areas without man-made water sources such as water reservoirs.

2. The Kingston Project, $8 \mathrm{~km}$ north of Camrose, attempts to create more open water in a shallow wetland area through the use of level ditching. Waterfowl need open water for brood rearing and moulting. Digging ditches throughout the wetland also deepens channels which hold water when shallower areas dry up. Material excavated can be used for waterfowl nesting islands and loafing bars.

Lesson 2

Activity 1

\begin{tabular}{|c|c|c|c|c|c|c|c|c|c|c|c|c|c|c|c|c|c|c|c|}
\hline & & & $F$ & $E$ & & & $R$ & & & $C$ & & & & & & & & & \\
\hline 0 & $D$ & Z & B & V & 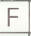 & $\bar{x}$ & $\mathrm{H}$ & C & $\mathrm{J}$ & $W$ & & 0 & $\mathrm{~L}$ & - & IVI & $\mathrm{N}$ & $x$ & 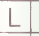 & $\mathrm{O}$ \\
\hline$E$ & $\mathrm{~L}$ & K & $\mathrm{H}$ & $\mathrm{N}$ & $A$ & $\mid$ & $D$ & $\mathrm{~A}$ & $N$ & $A$ & $c$ & $P$ & $B$ & $Y$ & F & $\mathrm{K}$ & V & $\mathrm{N}$ & 1 \\
\hline 1 & 1 & G & Z & $W$ & 1 & $\mathrm{~L}$ & D & L & 1 & $F$ & $E$ & $\mathrm{~L}$ & $\mathrm{E}$ & $\mathrm{M}$ & A & $\mathrm{H}$ & $x$ & $\mathrm{~T}$ & A \\
\hline $\mathrm{J}$ & $W$ & $\mathrm{~N}$ & 0 & 1 & $\mathrm{~T}$ & A & $R$ & $E$ & D & $E$ & $F$ & $S$ & $\mathrm{R}$ & 1 & $M$ & $\mathrm{Q}$ & $\mathrm{A}$ & B & $\mathrm{N}$ \\
\hline $\mathrm{J}$ & $\mathrm{N}$ & K & 0 & $\mathrm{G}$ & $C$ & K & $\mathrm{N}$ & 1 & $\mathrm{~L}$ & $x$ & $\mathrm{~L}$ & $D$ & $\mathrm{~T}$ & 0 & B & 1 & 0 & $F$ & $M$ \\
\hline$M$ & $\mathrm{~A}$ & S & $T$ & $S$ & 1 & L & A & $\mathrm{R}$ & $U$ & $\mathrm{~T}$ & A & $\mathrm{N}$ & A & $E$ & C & $\mathrm{H}$ & $E$ & $E$ & $P$ \\
\hline$N$ & 1 & $R$ & $P$ & $\mathrm{~F}$ & $\mathrm{~N}$ & $\mathrm{P}$ & 0 & 0 & 1 & $G$ & A & $P$ & 0 & 0 & Q & $D$ & Q & $R$ & $\mathrm{H}$ \\
\hline Q & $\mathrm{D}$ & A & $\mathrm{J}$ & $P$ & $\mathrm{~J}$ & $\mathrm{R}$ & 1 & $S$ & $R$ & C & S & $\mathrm{Q}$ & S & $\mathrm{J}$ & $E$ & B & S & U & $\mathrm{R}$ \\
\hline$F$ & $A$ & $T$ & $\cup$ & $\mathrm{N}$ & L & 1 & $M$ & 1 & $\mathrm{~T}$ & $E$ & D & S & $\mathrm{K}$ & $R$ & S & $R$ & $K$ & $\mathrm{~T}$ & $R$ \\
\hline 1 & $\mathrm{~N}$ & U & $S$ & $Z$ & $T$ & C & $\mathrm{L}$ & $\mathrm{V}$ & $\mathrm{T}$ & S & A & $T$ & A & $\mathrm{L}$ & $E$ & $\mathrm{~W}$ & $\mathrm{M}$ & $A$ & S \\
\hline$S$ & A & $P$ & $\mathrm{~K}$ & $T$ & $x$ & D & $\mathrm{N}$ & $U$ & $\mathrm{D}$ & $E$ & 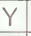 & $T$ & $\mathrm{M}$ & $\mathrm{N}$ & $U$ & 0 & $K$ & $\mathrm{~N}$ & Z \\
\hline $\mathrm{H}$ & C & $T$ & C & $\mathrm{V}$ & $\mathrm{N}$ & E & $P$ & A & $M$ & $\mathrm{~V}$ & 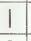 & $U$ & $\mathrm{~W}$ & $\mathrm{~N}$ & B & $B$ & Q & $\mathrm{N}$ & $W$ \\
\hline A & $W$ & $W$ & $U$ & $C$ & 0 & $F$ & $\mathrm{R}$ & A & $U$ & 0 & $S$ & 0 & $\mathrm{D}$ & $x$ & $x$ & $S$ & $A$ & $E$ & $E$ \\
\hline $\mathrm{N}$ & $\mathrm{V}$ & G & $\mathrm{D}$ & $Y$ & 1 & $\mathrm{~T}$ & $\mathrm{G}$ & $F$ & $\mathrm{~N}$ & C & D & $Y$ & $\mathrm{P}$ & $\mathrm{V}$ & $\mathrm{G}$ & 1 & $U$ & $z$ & $\mathrm{~L}$ \\
\hline 7 & $P$ & $\mathrm{H}$ & Z & $\mathrm{V}$ & $S$ & $\mathrm{Q}$ & $D$ & A & 1 & $\mathrm{~N}$ & $\mathrm{Q}$ & $W$ & $\mathrm{~W}$ & $\mathrm{~L}$ & D & $\mathrm{J}$ & $S$ & $S$ & $B$ \\
\hline$W$ & $\mathrm{H}$ & $x$ & $K$ & $R$ & 1 & $F$ & $\mathrm{~N}$ & $U$ & A & C & 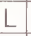 & 1 & B & $A$ & Y & $S$ & $\mathrm{M}$ & $R$ & 1 \\
\hline 1 & $\mathrm{Z}$ & D & $\mathrm{M}$ & $\mathrm{N}$ & $\mathrm{V}$ & C & $A$ & $\mathrm{~L}$ & $x$ & A & $M$ & 0 & $\mathrm{~N}$ & $E$ & $\mathrm{~T}$ & $\mathrm{~J}$ & $B$ & $E$ & $P$ \\
\hline $\mathrm{L}$ & $\mathrm{D}$ & G & $F$ & $\mathrm{~N}$ & 1 & Q & $\mathrm{H}$ & $\mathrm{S}$ & 1 & $F$ & C & A & $\mathrm{U}$ & $\mathrm{F}$ & 0 & $\mathrm{U}$ & $\mathrm{R}$ & $\mathrm{H}$ & D \\
\hline D & $L$ & 1 & $F$ & $E$ & $D$ & $\mathrm{E}$ & $R$ & $\mathrm{G}$ & D & $K$ & C & $Y$ & S & V & $\mathrm{R}$ & & & $T$ & $F$ \\
\hline
\end{tabular}

\section{Lesson 3}

Activity 1

A. Pond B. Marsh C. River D. Lake E. Bog

Activity 2

(c) Wetlands are inhabited by live organisms like plants, fish, insects and microorganisms. Water levels in wetlands change constantly due to evaporation, rainfall, melting snow and soil drainage.

(d) Pouring sand into a wetland reduces the depth of the wetland. If enough sand is poured in, the wetland disappears.

The process can be reversed by digging out the area which returns it to a wetland.

(e) The food coloring disperses throughout the container just as a poison does throughout a wetland. In a real wetland, poison kills some of the plants and animals living there. Other organisms which rely on the poisoned plants and animals are affected too and eventually the whole food chain is affected.

\section{Activity 3}

1. moss 2 . herbs 3 . sedges 4 . bulrushes 5 . cattails

6. beaver 7. ducks 8 . herons 9. pelicans 10 . songbirds
Lesson 4

Activity 1

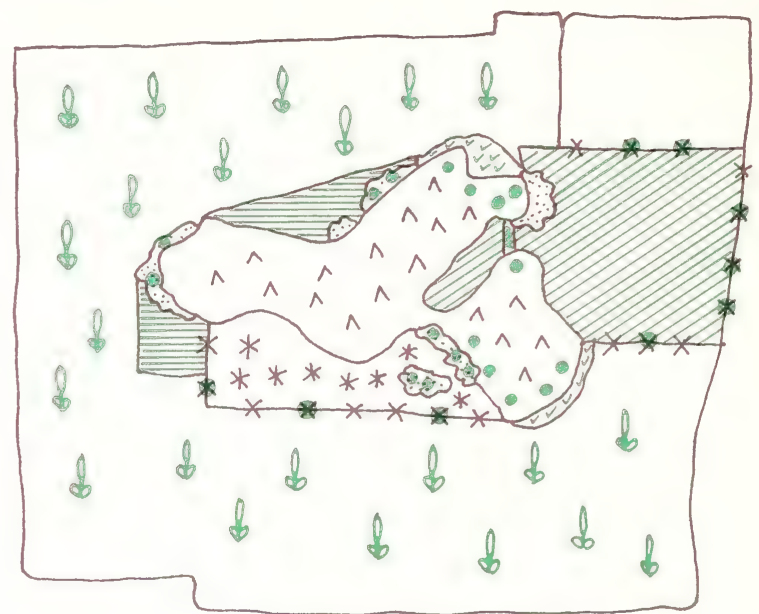

\section{Improvements}

Add Nesting Structures

Protect Peninsula with Ditch or Fence wa

Plant Cover Along Lake Edge $\square$

Reduce Stocking to Eliminate Overgrazing

Mow Hay After Nesting Season (July 1)

\section{Lesson 6}

Activity 2

Clear trees in small patches to create variety.

Plant grasses and legumes.

Seed clearings to foodplots such as oats, barley and legumes. Improve edges by cutting back trees to encourage brush and shrub growth

Retain some dead trees

Fence out livestock to prevent overgrazing.

Avoid large scale clearing.

Retain beaver ponds and manage water levels. 


\section{Lesson 7}

Activity 1

Plant shelterbelts to provide winter cover.

Protect forests from overgrazing.

Plant cover crops for winter protection and food sources.

Protect odd areas from burning and grazing.

Plant fencerows and hedges.

Use strip farming to reduce wind erosion and provide winter

food for wildlife.

Use zero tillage to provide food and cover.

Design cutting schemes for woodlots to encourage variety.

Improve edges by cutting back the forest to improve brush and shrub growth.

Seed woodland openings.

Retain a scattering of dead trees.

Install bird boxes.

Use water control structures at beaver dam sites.

Create temporary checkdams along eroded gullies.

Provide water sources by digging potholes or creating impoundments.

Fence off part of wetlands to prevent livestock access.

\section{Lesson 8}

Activity 1

Best grazing plants:

needle and thread, rough fescue, wheatgrass, blue grama grass

Species likely to use rangeland habitat:

deer, rabbit, pronghorn antelope, duck, songbird

\section{Lesson 9}

Activity 1

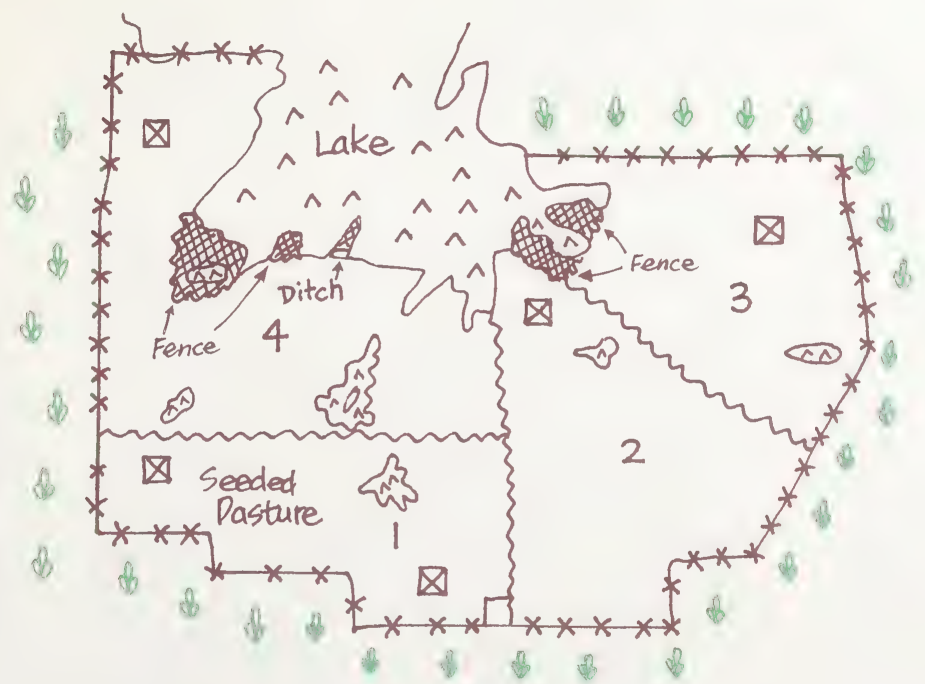

Grazing Rotation System

Early Late

Spring Summer Summer Fall

New Fences $\sim$

New Salt Blocks $\bowtie$

Protected Nesting Cover 


\section{Glossary}

Birth Rate - number of births per year relative to population size.

Bog - poorly-drained area, usually covered by mats of moss. It can range in size from one to several thousand acres.

Carrying Capacity - the number and kinds of wildlife a piece of land can support. Just as pasture can feed only so many head of cattle, a piece of land can feed only so many elk, deer and pheasants. Any extras must move on or die. Conifer - evergreen tree.

Cover Crop - a crop planted to keep cover on the soil to help prevent wind and soil erosion.

Death Rate - number of deaths per year relative to population size.

Deciduous Tree - sheds its leaves in the fall.

Ecosystem - communities of plants and animals and their environment.

Edge Effect - where two plant communities like woodlands and croplands come together.

Forb - a pasture herb that is not a grass.

Habitat - the environment where animals naturally live. For wildlife, habitat is made up mainly of food, cover and water.

Habitat Development - creating new habitat, enhancing existing habitat or restoring damaged habitat.

Habitat Protection - maintaining existing habitat.

Herbaceous Plants - broad-leafed plants such as dandelions.

Home Range - distance an animal travels within an area to satisfy its need for food, water and cover. The size of the home range varies with species.

Hopper - a container of food.

Lake - a body of water greater than 50 acres

(20 hectares) with a deepwater zone and surrounded by a ring of vegetation.

Leeward - protected from the wind.

Legume - any of a large group of plants of the pea family, characterized by pods enclosing seeds. Legumes are often cultivated into the soil to fertilize it because of their ability to store nitrogen.

Life Cycle - The series of changes any organism passes through from birth to death.

Rimiting Factor - Anything which prevents an animal population from increasing such as lack of food, cover or water, predators, hunting, disease, parasites, starvation and weather.
Marsh - wetland often located near a river or lake and subject to flooding and changing water levels. It is usually shallow and ranges insize from 5 to 50 acres ( 2 to 20 hectares).

Native and Non-Native Species - a native species is one that lives naturally in an area. A non-native species is one that is not naturally found in an area but has been brought to it by man and is able to survive.

Nutrient - anything that promotes growth. Pond - a shallow basin of water of two to five acres (one or two hectares) fed mainly by rain and snow and surrounded by a ring of emergent vegetation.

Predator - an animal that hunts other animals for food.

Rangelands - uncultivated areas that support herbaceous, grassy or shrubby plants. Less fertile than croplands, they are usually used for grazing and forage production.

River - a body of water whose main characteristic is moving water.

Seep Area - a moist, wet area where water has moved to the surface.

Strip Farming - planting strips of vegetation at right angles to prevailing winds to reduce wind erosion.

Succession - natural changes in vegetation. Suet - the hard, crumbly fat found in the body cavity of cattle and sheep.

Territory - an area within the home range which members of a species defend against members of the same species. Usually males defend a territory during breeding while females defend a territory during nesting and rearing young.

Vegetation Zones - Alberta's plants and animals can be divided into five broad regions or vegetation zones: the prairie region covering most of southern Alberta is mainly ranchland or under cultivation; the parkland region in east central Alberta has characteristics of the prairie region to the south and east, and the northern forest and foothills to the north and west; the foothil regions are ridged, heavily forested areas with scattered grasslands in the broader valleys and sparse trees along the higher crests; the boreal forest covering most of northern Alberta is covered by various mixes of poplar and white spruce; and the Alpine and Sub-alpine regions are mountainous areas above and below the tree line respectively.

Wetland - any water-filled depression.

Wildlife Population - species and numbers of wild animals living in a given area. 


\section{Fish and Wildlife Offices}

\section{Athabasca}

Box 1525

Provincial Building

TOG OB0

(675-2419)

Barrhead

Box 917

Provincial Building

6203 - 49 Street

TOG OEO

(674-3351)

(134-1236 RITE)

Blairmore

Box 1139

Crowsnest Mall

TOK OE0

(562-2856)

(182-1101 RITE)

Bonnyville

Box 1950

Provincial Building

TOA OLO

(826-3142)

Brooks

Box 909

Provincial Building

T0J 0J0

(362-5551)

(167-1130 RITE)

Calgary

\#200 Sloan Square

5920 - 1A St. S.W.

T2H 0G 1

(261-6423)

(161-6423 RITE)

Camrose

211 Provincial Building

T4V 1 P6

(672-4411)

(143-1125 RITE)

(143-1132 RITE)

Canmore

Box 1420

Provincial Building

TOL OMO

(678-2373)

Cardston

Box 388

Provincial Building

TOK OKO

(653-4331)

(186-1101 RITE)

Claresholm

Box 1148

Provincial Building

T0l 0T0

(625-3301)

(169-1101 RITE)

Cochrane

Box 1420

Provincial Building

TOL OW0

(932-2388)

Cold Lake

Box 158

Public Works Building

TOA 0V0

(639-3377)

Drumbeller

Box 1918

Provincial Building

TOJ 0 Y0

(823-5740)

(164-1114 RITE)

Edmonton

Main Floor, Room \#109

10363 - 108 Street

Sun Building

(427-3574)

Edson

Box 1390

Chanking Building

4926 - 1st Ave.

TOE OPO

(723-3341)

(130-1101 RITE)

\section{Elbow Ranger Station}

Bag 1, Bragg Creek

TOL OK0

(949-3754)

Evansburg

Box 216

Grassi Building

TOE 0T0

(727-3635)

Fairview

Box 879

Provincial Building

TOH 1 LO

(835-2737)

Foremost

Box 238

Volliner Building

TOK 0X0

(867-3826

Fort Chipewyan

Box 330

A.H.C. House

TOA 1 G0

(697-3636)

Fort McMurray

Room 205

9714 Main Street

T9H 1S4

(743-7200)

(136-7200 RITE)

Fort Vermilion

Box 698

TOH 1 N0

(926-2238)

Fox Creek

Box 512

1st Avenue S.W.

Kaybob Drive

TOH 1 PO

(622-3421)

Grande Cache

Box 570

Provincial Building

TOE OYO

(827-3356)

Grande Prairie

* 1801 Provincial Building

10320 - 99 Street

T8V 6J4

(539-2265)

(121-2265 RITE)

Hanna

Provincial Building

Courier Box 23

TOJ $1 \mathrm{PO}$

(854-4451)

(186-1101 RITE)

High Level

Box 28

Sellers and Brown Building

TOH 1 Z0

(926-2238)

High Prairie

Box 236

Provincial Building

TOG $1 \mathrm{E} 0$

(523-4561)

(122-1101 RITE)

High River

Box 399

Provincial Building

TOL $1 \mathrm{~B} 0$

(652-3232)

(177-1111 RITE)

Hinton

Box 303

Commercial Building

TOE $1 \mathrm{BO}$

(865-3361)

(132-1101 RITE)

Kananaskis

Kananaskis Provincial Park

Box 1420

Cochrane, Alberta

TOL OWO

(591-7222)
Lac La Biche

Box 275

Provincial Building

TOA $2 \mathrm{CO}$

(623-4474)

(137-1247 RITE)

Leduc

Box 918

5907 - 45 Street

T9E 2 Y 5

(986-6775)

Lethbridge *

Sun Centre

530-8 Street South

T1J 2J8

(329-5266)

(181-5266 RITE)

Lloydminster

Provincial Building

5124 - 50 Street

T9V 0M3

(875-5506)

(145-1101 RITE)

Manning

Box 720

Civic Building

TOH $2 \mathrm{MO}$

(836-3065)

Medicine Hat

Main Floor, Chinook Place

623-4 Street S.E.

T1A 0L1

(529-3680)

(184-1680 RITE)

Nordegg

General Delivery

TOM $2 \mathrm{HO}$

(721-3949)

Olds

Box 1023

Provincial Building

TOM 1 P0

(556-8421)

(154-1215 RITE)

Oyen

Box 64

Provincial Building

T0J 2J0

(664-3614)

Peace River*

P.O. Bag 900-38

TOH 2X0

(624-6246)

(120-1246 RITE)

Pincher Creek

2nd Floor

Provincial Building

TOK $1 \mathrm{WO}$

(627-3366)

(180-1113 RITE)

Ponoka

Box 547

Provincial Building

TOC $2 \mathrm{HO}$

(783-3337)

(159-1011 RITE)

Provost

Box 549

5129 - 50 Street

T0B 3S0

(753-2433)

Red Deer *

Box 5002, 3rd Floor

Parkland Square

4901 - 48 Street

T4N 0M4

(343-4142)

(151-5142 RITE)

Rocky Mountain House*

Box 388 .

Mountain Ridge Plaza

TOM 1 TO

(845-5357)

St. Paul *

Box 1450

Eldorado Building

TOA 3A0

(645-6212)

(139-1313 RITE)

Slave Lake

Box 1370

Development Building

TOG 2AO

(849-2281)

(135-1217 RITE)

Smoky Lake

Box 690

Provincial Building

T0A $3 \mathrm{CO}$

(656-3556)

Stettler

Box 298

Public Services Building

TOC 2LO

(742-4481)

(153-1119 RITE)

Stony Plain

Box 727

Provincial Building

TOE 2 G0

(963-6131)

Strathmore

Box 537

3rd Avenue \& 3rd Street

TOJ $3 \mathrm{HO}$

(934-3422) 


\section{Ducks Unlimited CanadaOffices}

Provincial Office Edmonton

11409 - 163 Street

Edmonton, Alberta

T5M 3 Y3

Phone: 452-4911

Central District Office

5013 - 49 Street

Camrose, Alberta

T4V 1N5

Phone: 672-6786

Southern District Office

11, 311 - 9 Street, E.

Brooks, Alberta

TOJ 0J0

Phone: 362-4827
6, 321A - 6 Street, S. Lethbridge, Alberta T1J 2 C7

Phone: 328-8155

Box 2170

St. Paul, Alberta

TOA 3 A0

Phone: 645-4767

Box 134

Tofield, Alberta

T0B 4J0

Phone: 662-3810
Box 516

Grande Prairie, Alberta

T8V OR6

Phone: 432-7960

Box 1212

Brooks, Alberta

TOJ 0J0

Phone: 362-3825

Box 959

Hanna, Alberta

TOJ 1 P0

Phone: 854-3737
18, 4609 Gaetz Avenue Red Deer, Alberta R4N 3Z9

Phone: 342-1314

Box 59

Strathmore, Alberta

TOJ $3 \mathrm{HO}$

Phone: 934-3102

Box 488

Westlock, Alberta Phone: 349-4848

\section{References}

Beaver Ponds. National 4-H Council, Washington, D.C. 4pp.

Controlling Water Levels in Beaver Ponds. Fish and Wildlife Division, Alberta Energy and Natural Resources. 1980. 12pp.

Dig Your Own. Manitoba Department of Natural Resources. 1980. 12pp.

Environmental, Land Use and Wildlife Management Concepts for the Junior and Senior 4-H Programs. PRISM

Environmental Management Consultants. 1982.

Fish and Wildlife Policy for Alberta. Fish and Wildlife Division, Alberta Energy and Natural Resources. 1982. 24pp.

Harrowsmith (June/July, 1983). The Landscaped Oasis. Ron Allensen. 8 pp.

Homes for Wildlife. Cooperative Extension Service, University of Nebraska-Lincoln. $14 \mathrm{pp}$.

Man and Wildlife in a Shared

Environment. Environment Canada, Canadian Wildlife Service. 1982. 53pp.

Nest Boxes for Birds. Environment Canada, Canadian Wildlife Service. 1977. 8 pp.

Planning for Wildlife in Cities and Suburbs. Fish and Wildlife Service, U.S. Department of the Interior. 1978. 64 pp.

Preservation of Wetland Habitat.

Canadian Wildlife Federation. 12 pp.

Principles of Wildlife Management. Cooperative Extension Service, University of Idaho. $16 \mathrm{pp}$.
Range: Its Nature and Uses. Public Lands Division, Alberta Energy and Natural Resources. 1981. 34 pp.

The Health of the Land: Salinity, Burning, Depredation, Grazing Systems, Stubble Mulching, Zero-Tillage and Water Control. Ducks Unlimited Canada. 7 pamphlets.

The Sweet Smell of Success. Ducks Unlimited Canada. 2 pp.

Waterfowl Management. National 4- $\mathrm{H}$ Council, Chicago, Illinois. 16 pp.

Wetlands. Environment Canada, Canadian Wildlife Service. 1980. 6 pp.

Wetlands Affect You and Me. Cooperative Extension Service, Michigan State University. $16 \mathrm{pp}$.

Wildlife Ecology. Agricultural Extension Service, University of Tennessee. 1979. 44 pp.

Wildlife Foods. National 4-H Council. Chicago, Illinois. 8 pp.

Wildlife Habitat: A Handbook for Canada's Prairies and Parklands. Environment Canada, Canadian Wildlife Service. 1981. 51pp.

Wildlife in Your Backyard. Canadian Wildlife Federation. 1980. 16 pp.

Wildlife Management. Canadian Wildlife Federation. 1983. 16 pp.

Woodlands and Wildlife: Making Your Property Attractive to Wildlife. Jenny Hassinger et al. Penn. State University. 1979 . 


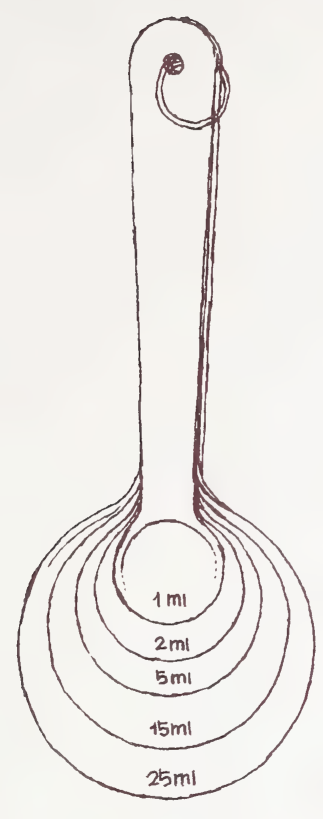

Metric measures are available in these sizes

$250 \mathrm{~mL}$ replaces $1 \mathrm{cup}$ $500 \mathrm{~mL}$ replaces 2 cups

\section{Metric Conversion Table}

\section{Approximate Conversion to}

Metric Measures

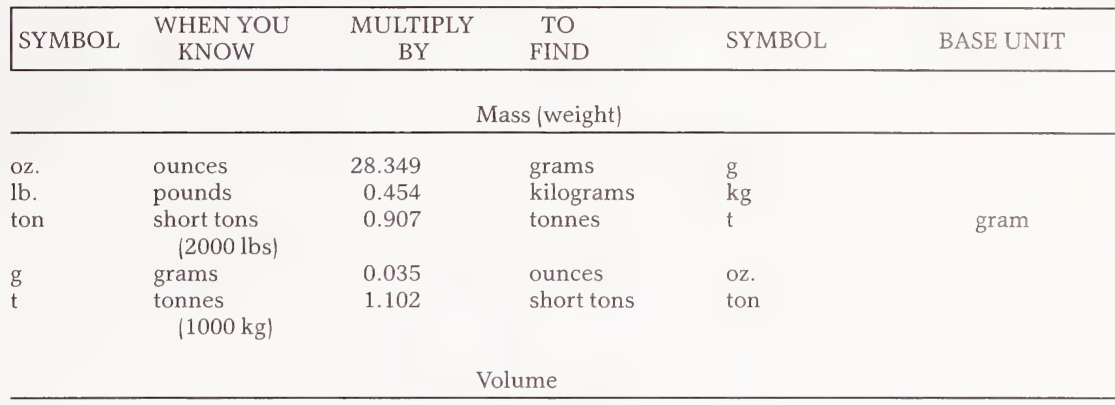

\begin{tabular}{llrlr}
\hline tsp. & teaspoons & 5 & millilitres & $\mathrm{mL}$ \\
tbsp. & tablespoons & 15 & millilitres & $\mathrm{mL}$ \\
fl.oz. & fluid ounces & 28.413 & millilitres & $\mathrm{mL}$ \\
pt. & pints & 0.568 & litres & $\mathrm{L}$ \\
qt. & quarts & 1.137 & litres & $\mathrm{L}$ \\
gal. & gallons & 4.546 & litres & $\mathrm{L}$ \\
bu. & bushels & 36.370 & litres & $\mathrm{L}$ \\
& & & & \\
mL & millilitres & 0.035 & fluid ounces & $\mathrm{fl.oz}$. \\
L & litres & 1.760 & pints & $\mathrm{pt}$. \\
$\mathrm{L}$ & litres & 0.880 & quarts & qt. \\
$\mathrm{L}$ & litres & 0.220 & gallons & $\mathrm{gal}$. \\
$\mathrm{L}$ & litres & 0.027 & bushels & $\mathrm{bu}$.
\end{tabular}

Length

\begin{tabular}{lllll}
\hline $\begin{array}{l}\text { in. } \\
\mathrm{ft} .\end{array}$ & inches & 2.540 & centimetres & $\mathrm{cm}$ \\
$\mathrm{yd}$. & feet & 0.305 & metres & $\mathrm{m}$ \\
$\mathrm{mi}$. & $\begin{array}{l}\text { yards } \\
\text { miles }\end{array}$ & 1.609 & $\begin{array}{l}\text { metres } \\
\text { kilometres }\end{array}$ & $\mathrm{m}$ \\
$\mathrm{km}$ \\
$\mathrm{mm}$ & millimetres & 0.0394 & inches & $\mathrm{in}$. \\
$\mathrm{cm}$ & centimetres & 0.394 & inches & $\mathrm{in}$. \\
$\mathrm{m}$ & metres & 3.281 & feet & $\mathrm{ft}$. \\
$\mathrm{m}$ & metres & 1.094 & yards & $\mathrm{yd}$. \\
$\mathrm{km}$ & kilometres & 0.621 & miles & $\mathrm{mi}$.
\end{tabular}

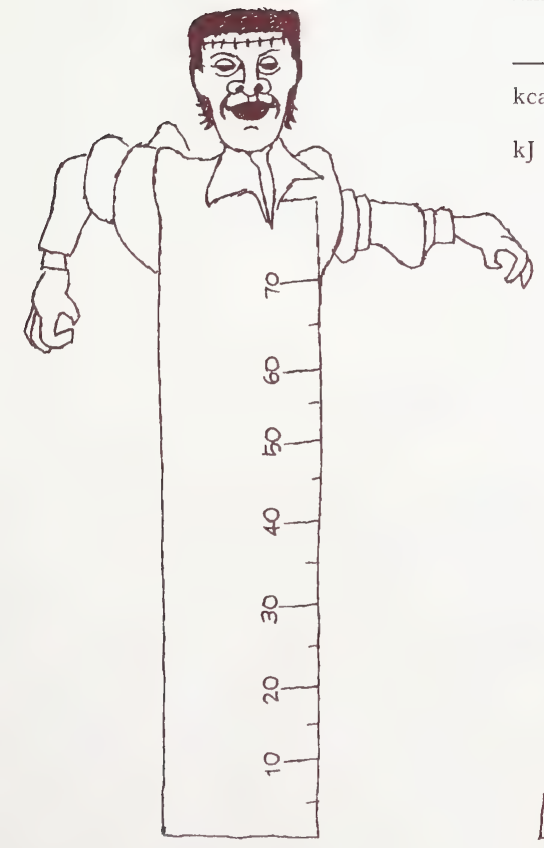

Munster Metre Measures Length

\begin{tabular}{|c|c|c|c|c|c|}
\hline \multicolumn{5}{|c|}{ Energy } & \\
\hline kcal & kilocalorie & 4.186 & kilojoules & $\mathrm{kJ}$ & \multirow[t]{2}{*}{ joule } \\
\hline $\mathrm{kJ}$ & kilojoules & 0.239 & kilocalories & kcal & \\
\hline
\end{tabular}


Metric Multiples and Prefixes Table

\section{Multiplying Factor}

$$
\begin{aligned}
1,000,000 & =10^{6} \\
1,000 & =10^{3} \\
100 & =10^{2} \\
10 & =10^{1} \\
\text { (Base Unit) } 1 & =10^{0} \\
0.1 & =10^{-1} \\
0.01 & =10^{-2} \\
0.001 & =10^{-3} \\
0.000,001 &
\end{aligned}
$$

Prefix

mega (meg a)

kilo (kil o)

hecto (hek to)

deka (dek a)

deci (des i)

centi (sen ti)

milli (mil i)

micro (mi kro)
Symbol

M

k

da

d

c

$\mu$

(These prefixes may be applied to all metric base units

Example: Base Unit $=$ litre

Add kilo to litre (symbol kL) $=$ kilolitre. The multiplying factor is 1000 . This means a kilolitre equals 1000 litres.)

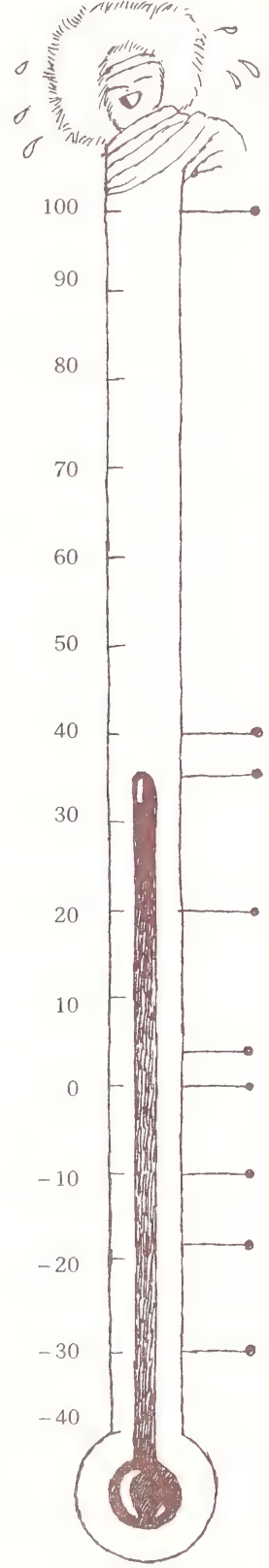

Water Boils $\left(100^{\circ} \mathrm{C}\right)$

Heat Wave $\left(40^{\circ} \mathrm{C}\right)$

Normal Body

Temperature $\left(37^{\circ} \mathrm{C}\right)$

Normal Room Temperature $\left(21^{\circ} \mathrm{C}\right)$

Refrigerator Temp-

erature $\left(4^{\circ} \mathrm{C}\right)$

Water Freezes $\left(0^{\circ} \mathrm{C}\right)$

Let's Skate on the

Pond $\left(-10^{\circ} \mathrm{C}\right)$

Freezer Temperature $\left(-18^{\circ} \mathrm{C}\right)$

Possible Car

Battery Trouble $\left(-30^{\circ} \mathrm{C}\right)$

Tom Thermometer Measures

Temperature in Degrees Celsius $\left({ }^{\circ} \mathrm{C}\right)$
Temperature: ${ }^{\circ} \mathrm{F}=9 / 5+32$

${ }^{\circ} \mathrm{C}=5 / 9-32$

\begin{tabular}{lcc}
\multicolumn{2}{l}{ Oven Temperatures: } \\
& ${ }^{\circ} \mathrm{C}$ & \multicolumn{2}{l}{${ }^{\circ} \mathrm{F}$} \\
Very slow & $120-135$ & $250-275$ \\
Slow & $150-165$ & $300-325$ \\
Moderate & $175-190$ & $350-375$ \\
Hot & $200-220$ & $400-425$ \\
Very Hot & $230-245$ & $450-475$ \\
Near boil & $245-290$ & $475-500$
\end{tabular}

Square Measure:

1 acre $=.4047$ hectares

\section{Additional Metric Information}

from:

Metric Branch

Alberta Government Services

12th Floor, Park Square

10001 Bellamy Hill

Edmonton, Alberta T5J 3C1

Metric Commission Canada

Box 4000

Ottawa, Ontario

Information Division

Canada Department of Agriculture

Ottawa, Ontario K1A 0C7

District Extension Office

OR

Publications Office

Alberta Agriculture

9718 - 107 Street

Edmonton, Alberta T5K 2C8 


\section{Fact Sheet 1}

Managing Alberta's Wildlife Resources

Wildlife management can be defined as managing wildlife populations, habitats and man to the mutual benefit of all three.

Wildlife population management is based on biological knowledge such as birth and death rates and food relationships. Wildlife managers try to keep populations at a level which best suits man's activities, the health of the habitat and the animals themselves.

Even more important than managing wildlife populations is managing habitats. Habitat management involves protecting and developing wildlife habitat. Habitat is vital to wildlife because it supplies food, water, cover and special needs necessary for survival.

\section{Natural Habitat Changes t}

Habitat constantly undergoes gradual changes known as succession. Ponds fill in becoming sedge meadows; shrubs replace grasses; trees replace shrubs; and so on until the biotic community (all plants and animals in an area) reaches its climax or fullydeveloped state. In the prairie region, grasses are the climax state. In the boreal forest, evergreens are the climax state. A forest usually remains in its climax state for many years. Eventually, trees grow old and die creating small new openings and taking the succession stage back to grasses and brush. Wind, fire, floods and disease can also take forests back to earlier stages of succession. Each change in plants means new habitat for wildlife. Different species move into the area and existing species begin to decline in numbers or move to more suitable habitat 
Metric Multiples and Prefixes Table

Multiplying Factor

\section{Prefix}

mega (meg a)

kilo (kil o

hecto (hek to)

deka (dek a)

deci (des i)

centi (sen ti)

milli (mil i)

micro (mi kro)
Symbol

M

$\mathrm{k}$

h

da

$\mathrm{d}$

c

$\mathrm{m}$

(These prefixes may be applied to all metric base units.

Example: Base Unit = litre

Add kilo to litre (symbol kL) $=$ kilolitre. The multiplying factor is 1000 . This means a

kilolitre equals 1000 litres.)

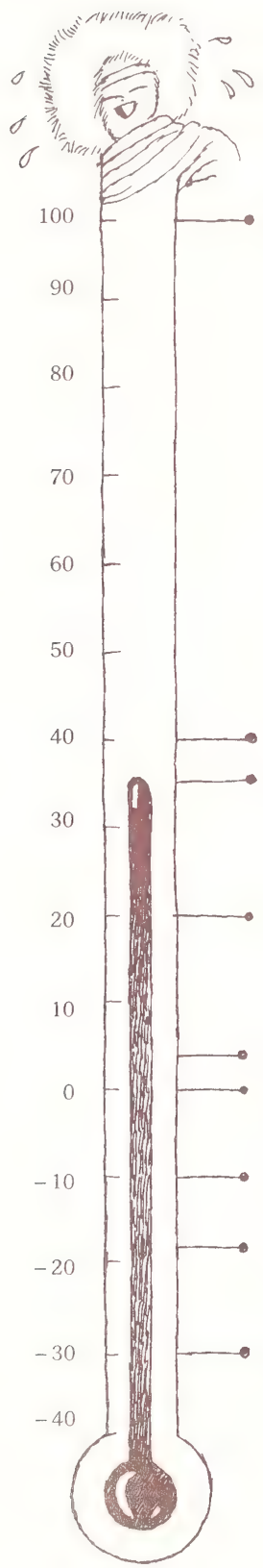

Water Boils $\left(100^{\circ} \mathrm{C}\right)$

Heat Wave $\left(40^{\circ} \mathrm{C}\right)$

Normal Body

Temperature $\left(37^{\circ} \mathrm{C}\right)$

Normal Room

Temperature $\left(21^{\circ} \mathrm{C}\right)$

Refrigerator Temp-

erature $\left(4^{\circ} \mathrm{C}\right)$

Water Freezes $\left(0^{\circ} \mathrm{C}\right)$

Let's Skate on the

Pond $\left(-10^{\circ} \mathrm{C}\right)$

Freezer Temperature $\left(-18^{\circ} \mathrm{C}\right)$

Possible Car

Battery Trouble $\left(-30^{\circ} \mathrm{C}\right)$

Tom Thermometer Measures

Temperature in Degrees Celsius $\left({ }^{\circ} \mathrm{C}\right)$
Temperature: ${ }^{\circ} \mathrm{F}=9 / 5+32$

${ }^{\circ} \mathrm{C}=5 / 9-32$

Oven Temperatures:

${ }^{\circ} \mathrm{C} \quad{ }^{\circ} \mathrm{F}$

Very slow 120-135 250-275

Slow 150-165 300-325

Moderate $\quad 175-190 \quad 350-375$

Hot 200-220 400-425

Very Hot $\quad 230-245 \quad 450-475$

Near boil $\quad 245-290 \quad 475-500$

Square Measure:

1 acre $=.4047$ hectares

\section{Additional Metric Information}

from:

Metric Branch

Alberta Government Services

12th Floor, Park Square

10001 Bellamy Hill

Edmonton, Alberta T5] 3C1

Metric Commission Canada

Box 4000

Ottawa, Ontario

Information Division

Canada Department of Agriculture

Ottawa, Ontario K1A 0C7

District Extension Office

OR

Publications Office

Alberta Agriculture

9718 - 107 Street

Edmonton, Alberta T5K 2C8 


\section{Fact Sheet 1}

\section{Managing Alberta's Wildilfe Resources}

Wildlife management can be defined as managing wildlife populations, habitats and man to the mutual benefit of all three.

Wildlife population management is based on biological knowledge such as birth and death rates and food relationships. Wildlife managers try to keep populations at a level which best suits man's activities, the health of the habitat and the animals themselves.

Even more important than managing wildlife populations is managing habitats. Habitat management involves protecting and developing wildlife habitat. Habitat is vital to wildlife because it supplies food, water, cover and special needs necessary for survival.

\section{Natural Habitat Changes}

Habitat constantly undergoes gradual changes known as succession. Ponds fill in becoming sedge meadows; shrubs replace grasses; trees replace shrubs; and so on until the biotic community (all plants and animals in an area) reaches its climax or fullydeveloped state. In the prairie region, grasses are the climax state. In the boreal forest, evergreens are the climax state. A forest usually remains in its climax state for many years. Eventually, trees grow old and die creating small new openings and taking the succession stage back to grasses and brush. Wind, fire, floods and disease can also take forests back to earlier stages of succession. Each change in plants means new habitat for wildlife. Different species move into the area and existing species begin to decline in numbers or move to more suitable habitat.

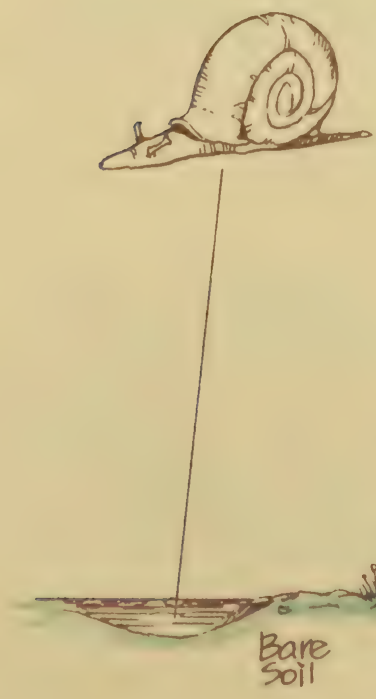

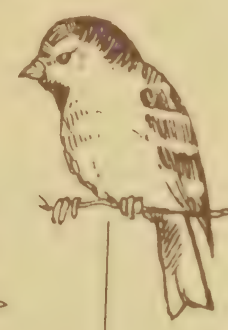
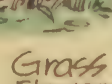

Howers

\section{Shrubse} short Trees

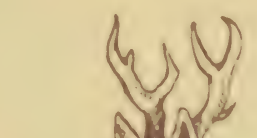

a

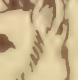

.

if
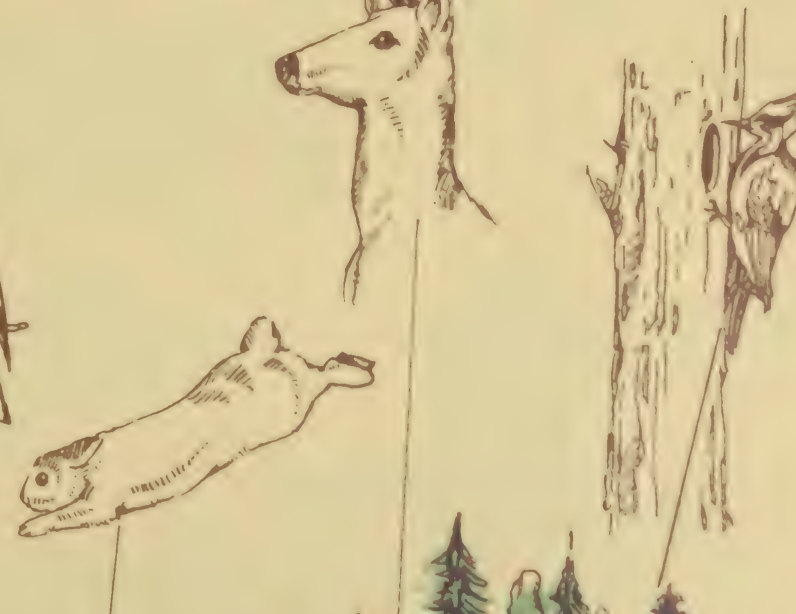

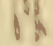 \\ in}




\section{Man-influenced \\ Habitat \\ Changes}

Man can and does change habitat in a number of ways. Some changes are beneficial while others are extremely harmful. Changes having broadest impact generally occur in Alberta's agricultural lands since these lands are capable of producing the best quality wildlife habitat. New "cleaner" farming techniques combine improved technology with a greater emphasis on productivity. Valuable wildlife habitat in formerly unproductive areas such as abandoned farmsteads, potholes and field corners is now cleared and cultivated. Larger, specialized operations such as farms with grain only are replacing the smaller mixed farms, reducing the plant variety important to good wildlife habitat. In some cases, these techniques harm both wildlife and the long-term health of the land.

Other threats to wildlife habitat include the constant expansion of cities and towns into wildlife areas. Industrial activities not only swallow wildlife habitat but harm wildlife in other ways such as through oil spills or the release of toxic chemicals into air and water.

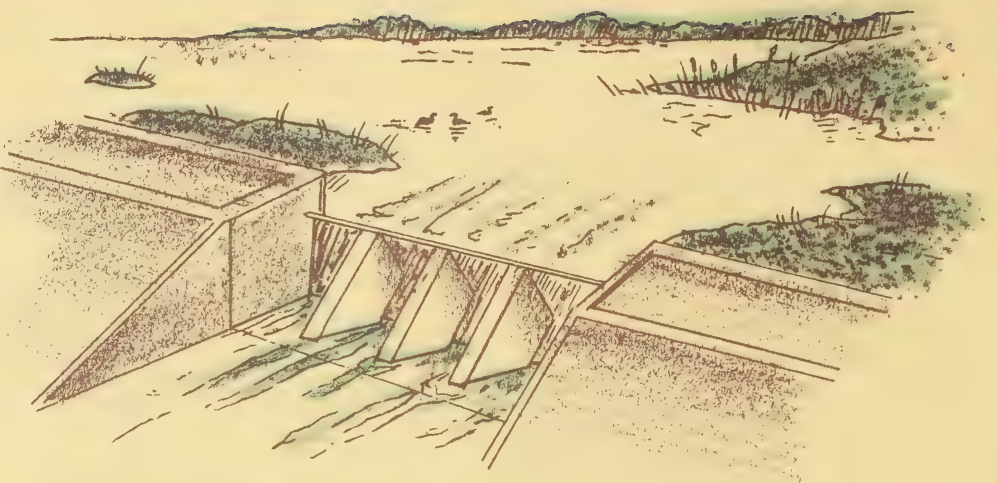

Some of man's activities benefit wildlife. Irregular patchwork clearing of climax forest adds variety to a woodlot, improving it for species such as deer, elk, black bear and many furbearing and bird species. Irrigation has created thousands of acres of habitat for waterfowl, marsh mammals, fish and upland birds. Legume and cereal crops provide important food sources for whitetailed deer, waterfowl and upland birds.

Man and wildlife can live together effectively provided neither threatens the well-being of the other. Man faces the challenge of balancing increasing pressures for greater agricultural productivity with programs to protect its valued wildlife resources. It is vital to the future health of both wildlife and the land to develop cooperative management programs which benefit both wildlife and agriculture. Federal and provincial governments use a number of methods to protect and develop habitat. Private associations such as Ducks Unlimited devote a great deal of time and money to habitat development projects. Perhaps the most effective of all, though, are individual landowners, farmers and homeowners who show their concern by considering wildlife in their land management plans.

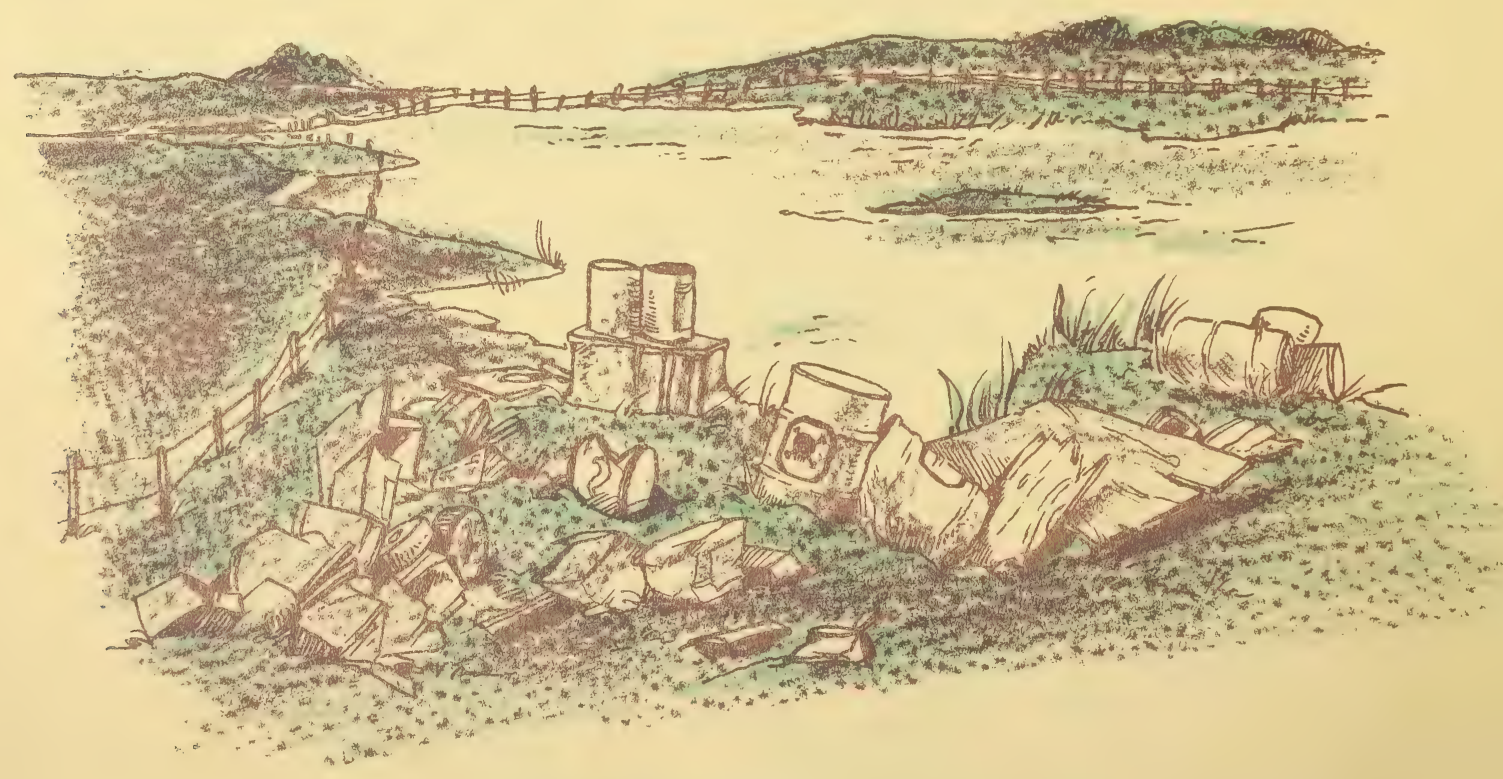




\section{Fact Sheet 2}

Habitat Management Tools

Habitat protection involves maintaining existing habitat. Habitat development means creating new habitat, enhancing existing habitat, or restoring damaged habitat.

\section{Protecting Habitat}

Government tools used to protect habitat include protecting and managing key sites, zoning, recommendations for bylaws and legislation.

\section{Protecting and Managing Key Sites}

The Canadian Wildlife Service acquires and maintains habitats for migratory birds and other wildlife. At present, the agency manages 39 wildlife areas covering 75,000 acres $(30,000$ hectares) across Canada.

Alberta Energy and Natural Resources manages 9 wildlife sanctuaries, 14 bird sanctuaries, and 51 protected wildlife areas.

\section{Zoning}

In areas like the Eastern Slopes of Alberta's Rocky Mountains which house a wealth of resources, conflicts in land use are bound to develop. To allow varied uses of the Eastern Slopes area as well as protect key habitats, the provincial government developed a policy for resource management. It breaks the area into zones such as Critical Wildlife Zone and General Recreation Zone, identifying permitted and restricted uses within each zone.

\section{Recommendations for Planning and Bylaws}

Municipal governments employ land use plans and bylaws to protect habitat on private lands Governments and agencies often ask the advice of the Fish and Wildlife Division of Alberta Energy and Natural Resources in forming these plans and bylaws.

\section{Legislation}

Legislative authority for fish and wildlife management is divided between the federal and provincial governments. Migratory bird populations are protected under the Migratory Birds Convention Act administered by the Canadian Wildlife Service. The Canada Wildlife Act expands this responsibility to protect migratory bird habitat and other wildife such as rare and endangered species. The Fish and Wildlife Division of Alberta Energy and Natural Resources administers the Federal Fisheries Act and Regulations which control harvest of fish. The Alberta Wildlife Act and Regulations also administered by the Fish and Wildlife Division, regulates harvest of wildlife game species, protects a number of non-game animals and provides an opportunitiy to initiate legislation to protect wildlife habitat.

\section{Developing Habitat}

The provincial government runs a number of programs to create, improve and restore wildlife habitat. More than 100 fish and wildlife projects have been undertaken under the "Buck for Wildlife" program. They include everything from creating new water bodies, to building islands for loafing and nesting waterfowl, to purchasing more than 2,800 hectares of wildlife habitat. Pilot projects underway are studying incentives as a means of encouraging landowners to retain fish and wildlife habitat. The Canadian Wildlife Service is also involved with habitat improvement projects for migratory birds

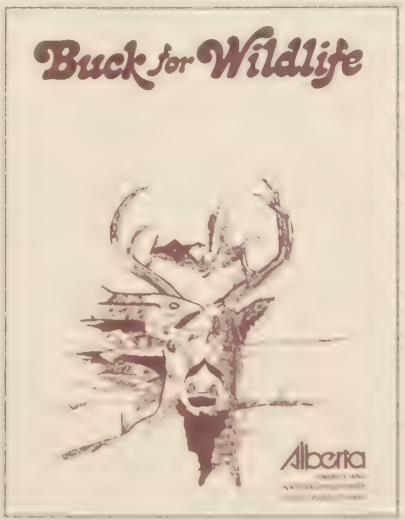




\section{Buck for Wildlife Projects}

- 1 Ridge Reservoir

- 2 Heninger's Reservoir Habitat Improvement Project

- 3 Tyrrel-Rush Lakes

- 4 Stirling Lake Habitat Improvement Project

- 5 Chin Reservoir Habitat Improvement Project

- 6 C.P.R. Reservoir Nesting Island Project

- 7 Walsh Flat

- 8 McVinnie Property Habitat Improvement Project

- 9 Stonehill Lake

- 10 Scandia Ranch

- 11 Lake Newell

- 12 Millicent Habitat Development Project

- 13 Elk Winter Range Fertilization Project (2 areas)

- 14 Streeter Basin Study

- 15 Porcupine Hills

- 16 Sheep River Fertilization Project

- 17 Elk Winter Range Improvements

-18 Eagle Lake Habitat Improvement Project

- 19 Moose Creek Habitat Improvement Project

- 20 Athabasca Ranch

-21 Shiningbank Moose Range Improvement Project

- 22 Chip Lake Habitat Improvement Project

- 23 Brazeau Osprey

- 24 Fallentimber Creek

-25 Namaka Lake

- 26 Dickson Dam

-27 Bigelow Reservoir Habitat Development Project

-28 Rowley Waterfowl Nesting Islands

- 29 Slack Slough

-30 Cygnet Lake

- 31 Buffalo Lake Habitat Improvement Project

- 32 Beaverhill Lake Habitat Improvement Project

- 33 Akasu Lake Nesting Island Project

- 34 Bens-Watt Lakes

- 35 Lychak Property Habitat Improvement Project

-36 Therien Lake

- 37 Whitford-Rush Lakes

- 38 Rochester Habitat Management Area

-39 Athabasca Elk Intercept feeding program

-40 Spring Creek Habitat Study

- 41 Simonette River

- 42 Birch Hills

\section{National Wildlife Areas}
$\triangle$ Blue Quills
Spiers Lake
Meanook

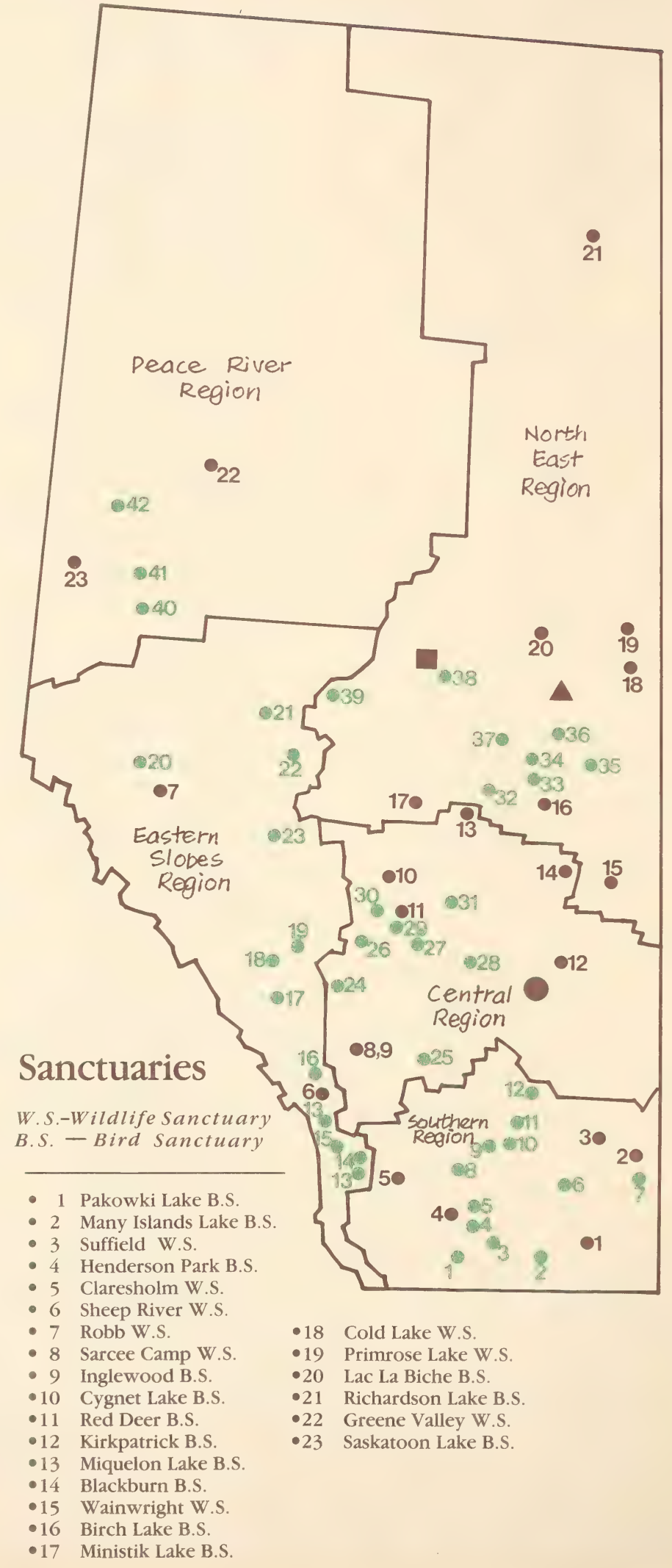




\section{Fact Sheet 3}

Wetland Habitat

Wetland is any water-filled depression. Plants and aquatic life in wetland areas need waterlogged soils to grow and reproduce. There are five major types of wetlands, each with its own characteristics: ponds, marshes, bogs, lakes and rivers.

A pond is a shallow basin of about two to five acres (one or two hectares) fed mainly by rain and melting snow. It usually is surrounded with a ring of cattails and bulrushes.

A marsh is often located near a river or lake and is subject to flooding and changing water levels. It is usually shallow and ranges in size from 5 to 50 acres (2 to 20 hectares). A wide range of vegetation such as grasses, rushes and sedges mingles with areas of open water in most marshes.

Bogs (muskeg) are poorlydrained areas usually covered by mats of moss. They range in size from one to many hundreds of acres. Vegetation includes trees, tall shrubs and herbs.

Lakes are usually greater than 50 acres ( 20 hectares) in size with a deepwater zone greater than one metre. Often they are surrounded by a ring of emergent vegetation.

The main characteristic of rivers is moving water. River valleys and islands support a wide variety of plants which make them important habitat areas for wildlife.

\section{Importance of Wildlife}

Each year Albertans drain or fill in thousands of acres of wetland to create more land for agriculture, industry and housing Wetland is often regarded as having little value, but wetlands not only provide habitat for many wildlife species, they also perform other important roles. They act as reservoirs to control flooding and erosion. They help maintain the water table, providing soil moisture and well water for farm use in dry years. They also serve as natural filtration systems to purify water. Cattails and bulrushes are able to absorb large amounts of nitrates, phosphates, mercury, lead and other heavy metals. In fact, lagoons containing these two plants are being used experimentally in Saskatchewan and Ontario as sewerage systems for small towns. Wetlands also provide many hours of recreation for hunters, fishermen, birdwatchers and photographers.

Vegetation around wetland is important to both landowner and wildlife. Grass and legume cover protects ditchbanks and streambanks from erosion. It also acts as a good emergency food source for livestock. Trees and shrubs around ponds reduce evaporation and help maintain a steady supply of water.

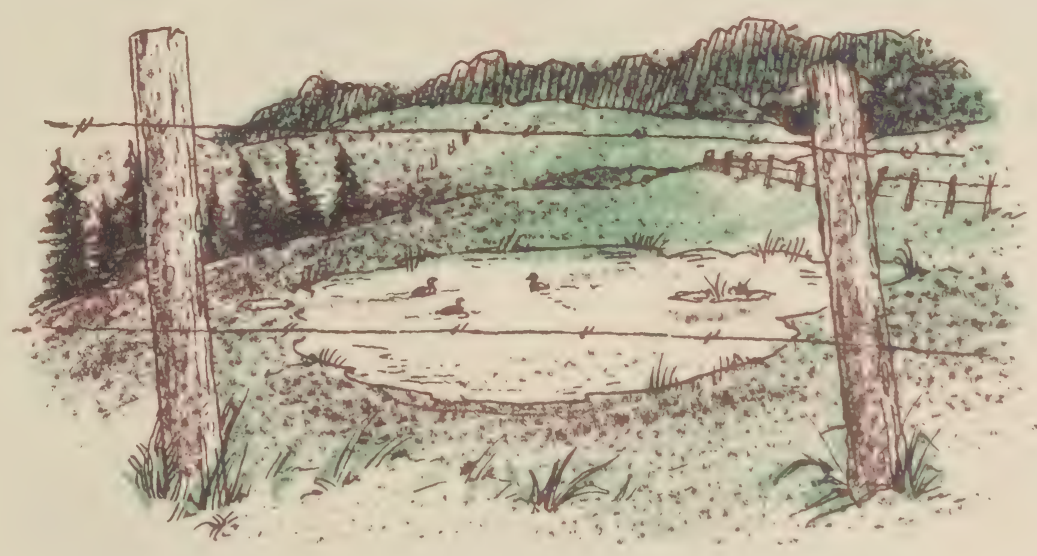


For wildlife species like prairie ducks, geese and marsh birds, marshy cover and vegetation around ponds and sloughs mean prime nesting areas. About 20 per cent of all ducks hatched in Canada are hatched in Alberta. Mink, mallards, pheasants, voles, deer mice, deer, and insect-eating songbirds such as warblers find food, cover and water along ditchbanks, streambanks and rights-of-way. Grass, forbs and shrubs along irrigation canals make good habitat for upland birds and small mammals. Large cattail patches offer cover during winter to upland birds (pheasants and sharptailed grouse) and small (meadow voles) and large mammals (deer).

The most remarkable wetlands in Alberta are in the prairie and parkland zones. Millions of depressions varying in size and depth dot the area. In the spring they fill with melting snow to form lakes, marshes and ponds.

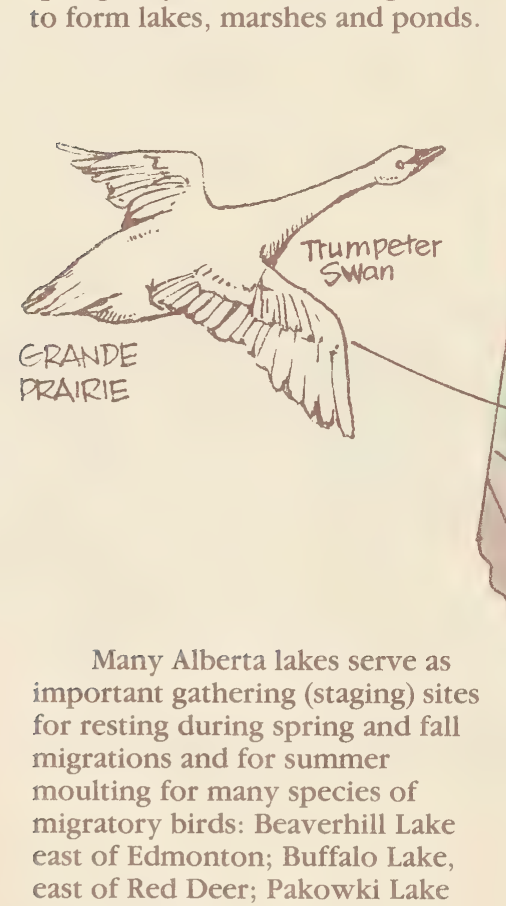

Many Alberta lakes serve as important gathering (staging) sites for resting during spring and fall migrations and for summer moulting for many species of migratory birds: Beaverhill Lake east of Edmonton; Buffalo Lake, east of Red Deer; Pakowki Lake south of Medicine Hat; PeaceAthabasca Delta and Hay-Zama Lakes in northern Alberta enjoy lots of bird traffic. Utikuma Lake north of Lesser Slave Lake is important to pelicans. Lakes near Grande Prairie provide nesting habitat for the rare trumpeter swan.
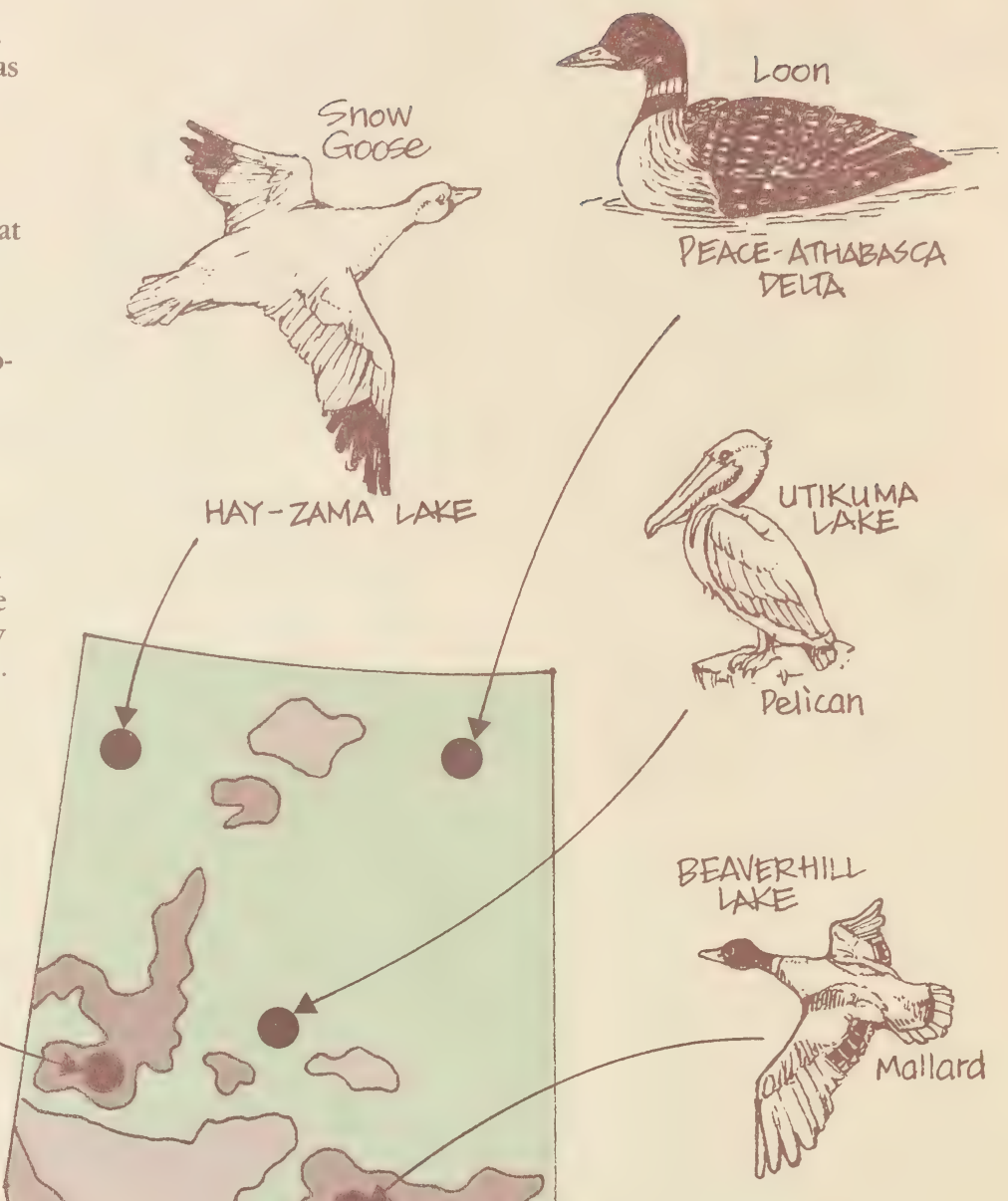
, (n)

. 


\section{Fact Sheet 4}

\section{Enhancing and Creating Wetlands}

\section{Maintain and Improve Cover}

Plant grasses and legumes next to wetland areas to provide nesting cover. Hay or mow wetland fringes after mid-June to avoid destroying nests and birds. Fence ponds and marshes having perimeters greater than one hundred metres. Allow livestock to graze these areas only after the nesting period is over. Avoid burning wetland edges as much as possible.

\section{Temporary Checkdams}

Use temporary checkdams along eroded gullies to control water flow or to change its direction. Checkdams can also be used to fill ponds and marshes in the spring. Make them of brush, loose stones, trash and straw bales. Hold them in place with wire and stakes. You can also place sod strips across the direction of flow. Plant alfalfa, clover, streambank fescue and wheatgrasses to stabilize the soil and provide nesting cover for waterfowl, upland gamebirds and other ground-nesting birds such as meadowlarks and sparrows.

Excavate Dugouts and Potholes

Dugouts and potholes provide water sources for both livestock and human consumption. They also provide water for fire protection. Make the dugout or pothole irregular in shape rather than square or rectangular to create more edge habitat for wildlife. Make a shallow zone to plant cattail, rush and slough grass roots obtained from nearby marshes. This habitat attracts ducks, geese, marsh birds, frogs and muskrats. Seed water plants along the shore and in shallows. If the dugout is more than three metres deep, use it to stock rainbow trout. For large dugouts, create islands in the middle using large rocks or excavated soil. Spread topsoil over the island. Seed it and protect it with a layer of straw or mulch. Prevent shorelines and banks from eroding by seeding them with clovers and water tolerant grasses.
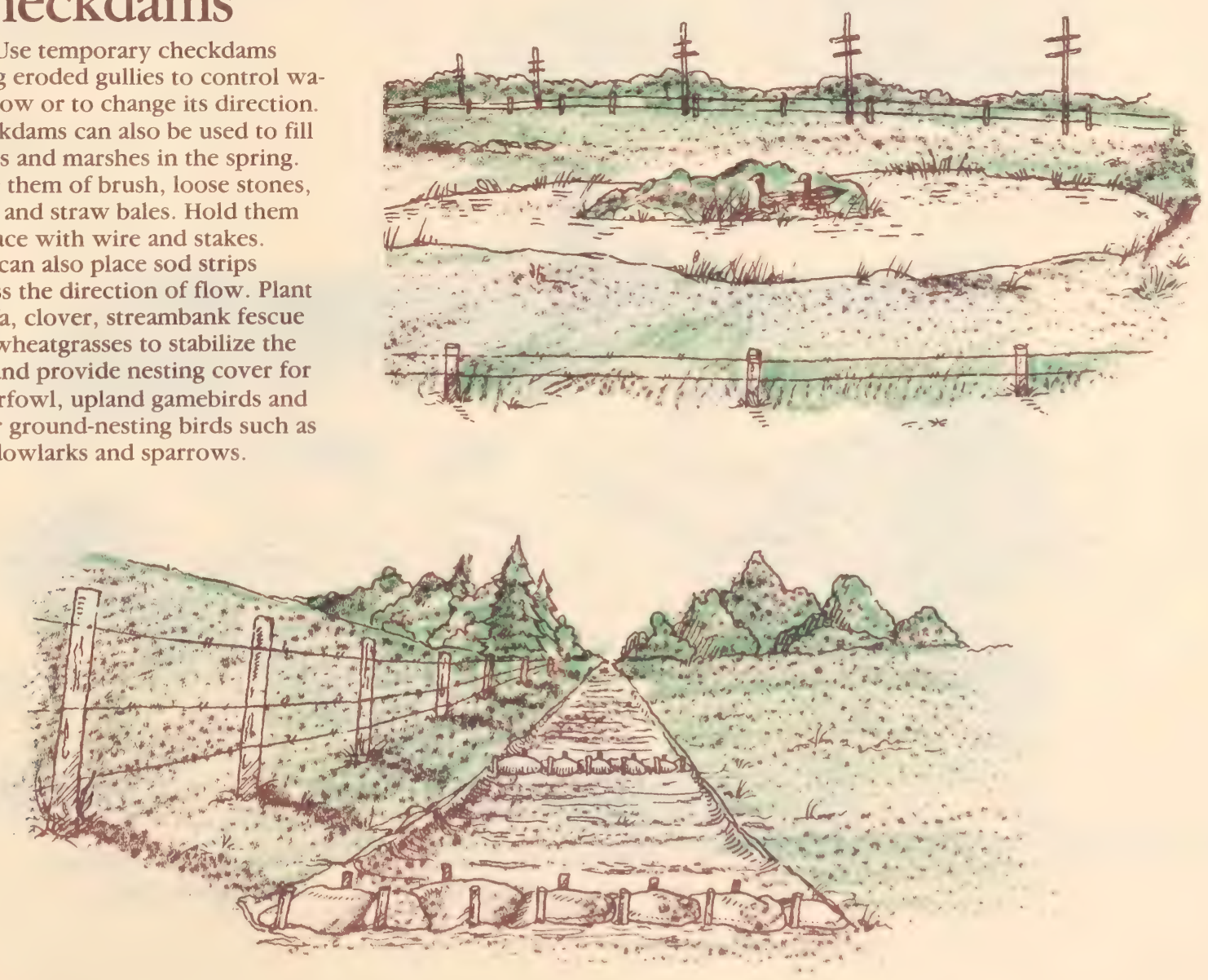
Nest boxes in the Boreal Forest and Northern Parkland areas are used by hole nesters such as goldeneye and bufflehead if no hollow trees can be found near the wetlands. Branches, twigs and nest debris should be cleaned from the boxes each year before nesting season. (See Fact Sheet 10 for instructions on how to build a nest box.)

Goose nesting structures are more variable than those for ducks. Where breeding geese are present, bind large round straw bales together and wrap them with stucco or paige wire. Place them on the leeward or protected side of small wetlands close to vegetation. Along rivers, wire baskets placed in large trees also serve as suitable nest sites.

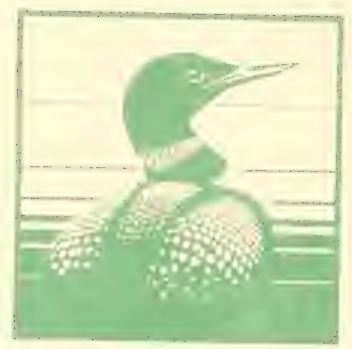

Watch for this loon on blue signs marking national wildlife areas and migratory bird sanctuaries.

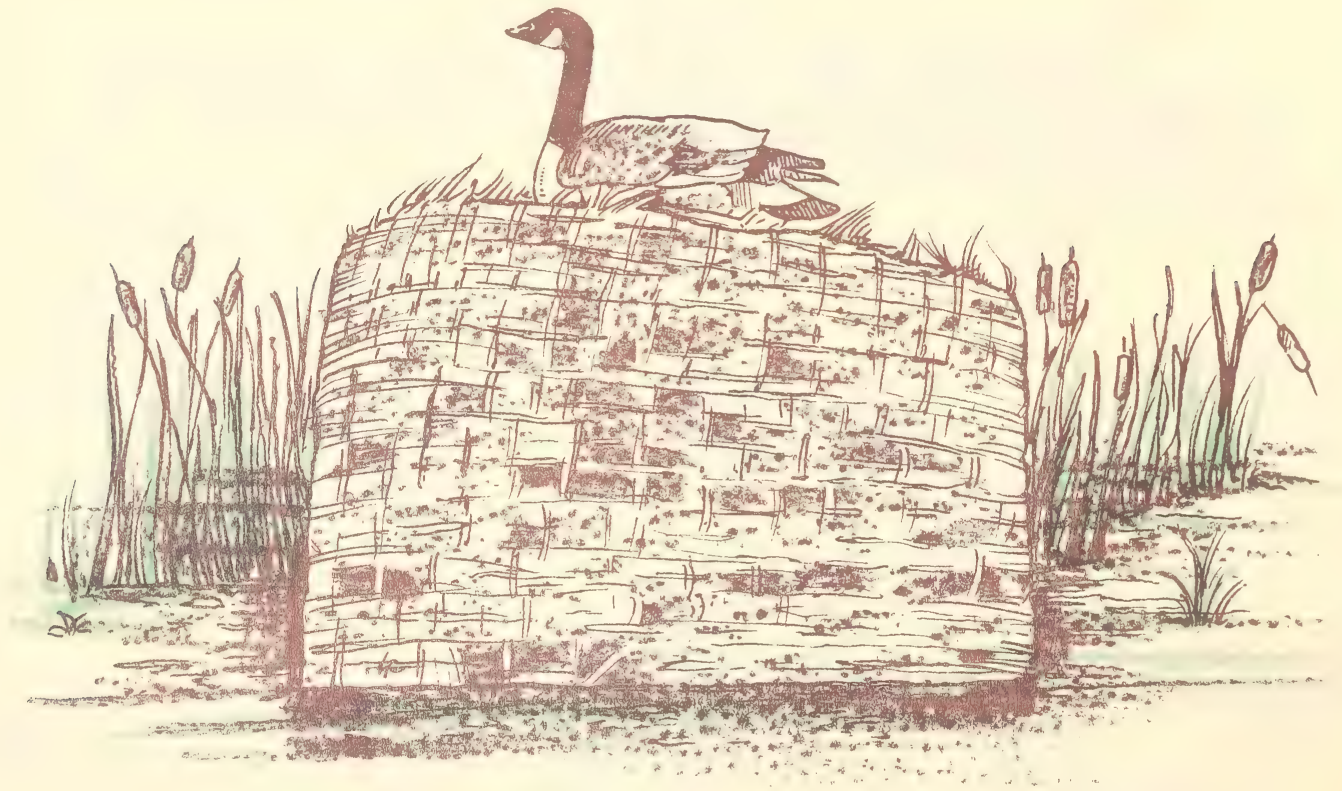




\section{Fact Sheet 5 \\ Woodland Habitat}

Woodlands are areas where trees and shrubs are the dominant vegetation. They include everything from natural forests and shrublands to man-made shelterbelts and hedgerows. Spruce, pine, fir, aspen poplar, willow, alder and birch are the most common types of trees in the province.

\section{Importance Of Woodlands}

Forests perform a number of important functions. Spongy surfaces soak up water and help control water run-off and erosion. Trees and shrubs produce valuable oxygen and remove carbon dioxide from the air. Woodlands provide all kinds of recreation hiking, camping, hunting and nature studying. Windbreaks and shelterbelts protect land, animals and buildings from the wind. Leaves capture dust particles reducing air pollution.

The importance of woodlands to wildlife depends on their stage of succession. Young forests provide the best wildlife habitat because they contain a variety of trees, shrubs, grasses and plants. As a forest matures, tree tops grow together forming a canopy over the forest floor. Only shaderesistant plants can survive under the canopy. Even lower branches of the trees begin to fall off. These forests support many different kinds of birds, especially cavity nesters like woodpeckers and flickers. Other wildlife species disappear because they cannot find food or cover.

A mature forest containing a mixture of evergreens and deciduous leaf-shedding trees attracts more birds than a stand of either type alone. Clumps of evergreens provide good winter cover. This value is increased if

\section{Edge Effect}

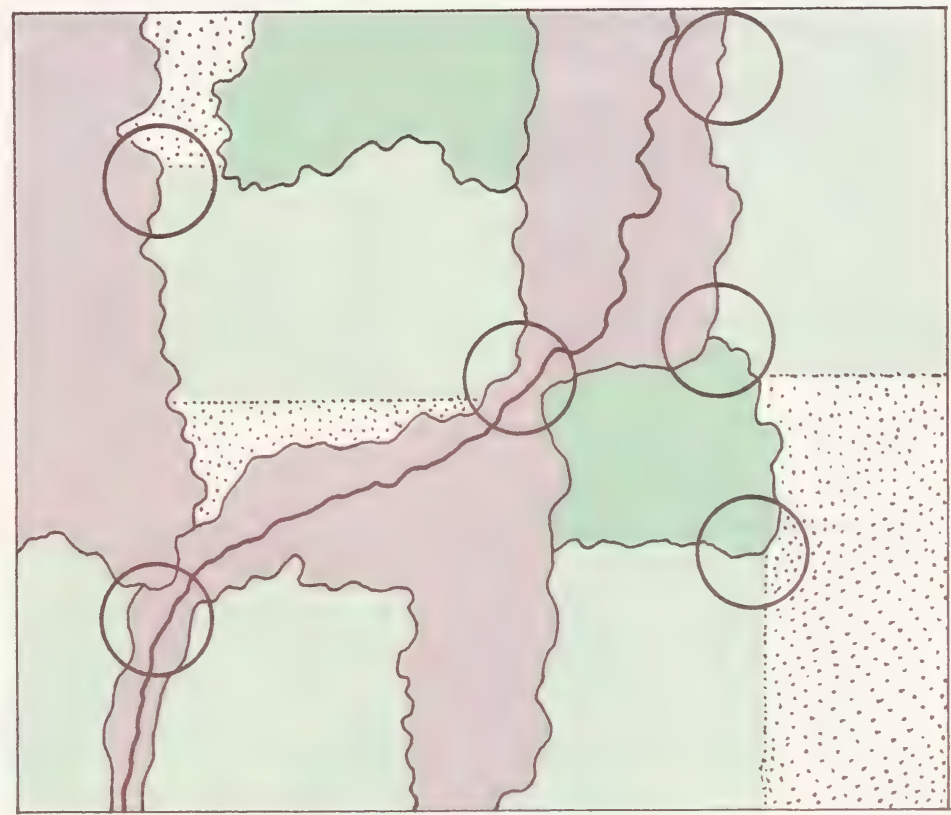

\section{$\square$ Woods(shelter) $\square$ Brush(shelter)
$\square$ cultivation (food)}

$\operatorname{Grass}($ food)

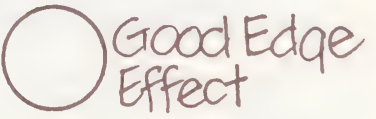

they are near brushy or herbaceous (plants with broad leaves such as dandelions) openings. Deer browse on their needles in winter if no other vegetation is available.

Grouse and snowshoe hares use lower branches for cover. However, too few evergreens may increase predator risk since predators can concentrate on the few hiding places available.

Edge or border areas where two plant communities such as woodlands and croplands come together are important to wildlife because of the wide variety of food and cover plants found in these areas. 
Beaver ponds in woodland areas also provide important wildlife habitat. Fish, birds and mammals eat the insects which thrive there. Fish, in turn, become food for kingfishers and herons. Many species of ducks use the ponds for nesting and raising broods. Muskrat, mink and otter use abandoned lodges and bank dens. Plants growing in openings created by fallen trees provide food for bears, deer, moose and geese. Small mammals living in grassy areas around the ponds attract food-seekers like greathorned owls, weasels, foxes and coyotes.

Beaver dams benefit landowners as well. They stabilize stream flow, slowing run-off in the spring. Beaver ponds catch sediments which erode with spring run-off. When the ponds eventually dry up, these sediments support rich plant growth. Beaver ponds also provide water sources for livestock and forest-fire control, especially during drier times of the year.

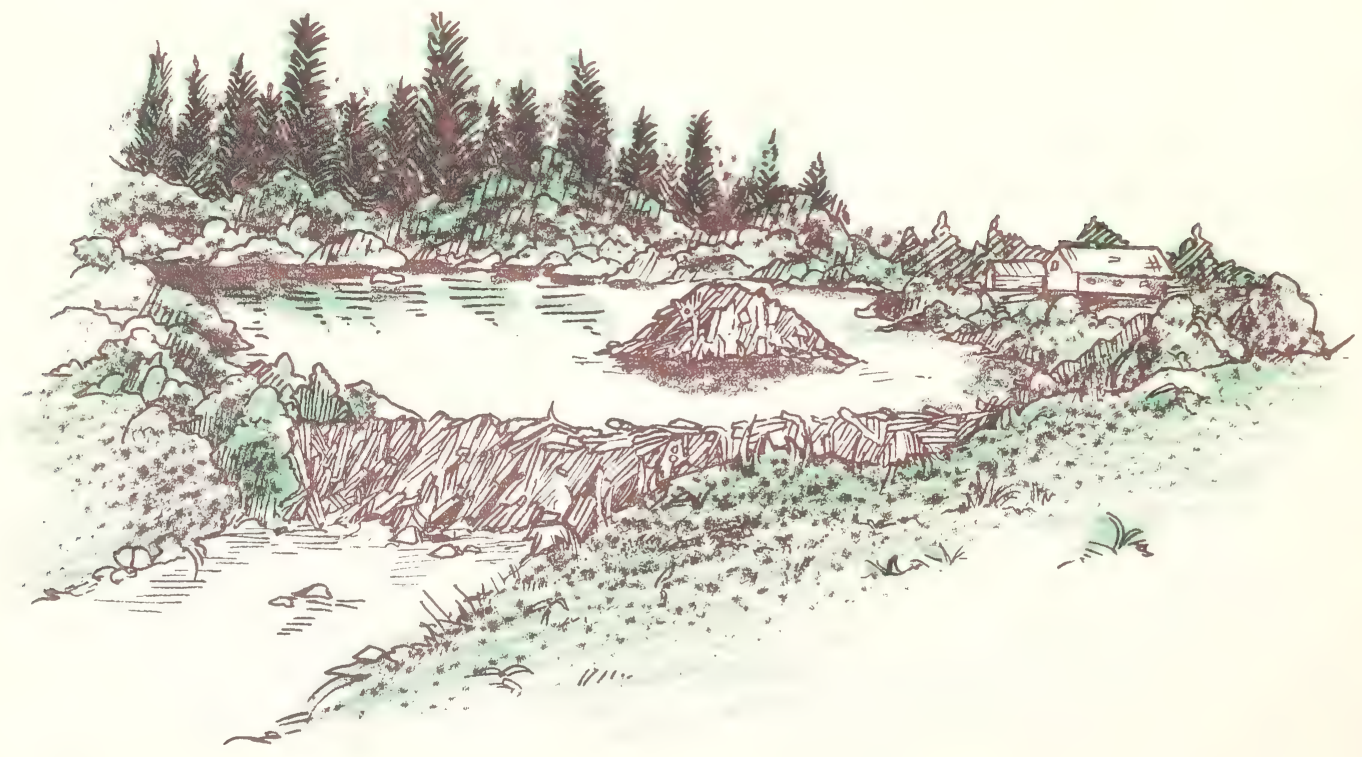




\section{Fact Sheet 6}

\section{Protecting and Enhancing Woodland Habitat}

\section{Selective \\ Cutting}

Wildlife are most attracted to an uncut woodland with lots of underbrush and a mixture of conifers and deciduous trees. However, a controlled cutting scheme provides advantages too. It encourages new growth of food and cover, creating variety and edge. For the landowner, it improves the woodlot as well as supplying firewood, fenceposts and lumber.
Clear trees in small patches or blocks by removing mature trees (15 centimetres in diameter or larger). Spread the blocks throughout the stand. A border of conifers with branches to the ground protects the woodlot from dry winds. Improve a large cutting or clearing openings of two to five acres (one to three hectares). Clear about ten to 30 per cent of the woodlot.
Avoid large-scale clearing on agricultural lands. If woodlands must be cleared to create more cropland, leave islands or fingers of trees in gullies and along streambanks to reduce erosion and to provide protection for livestock.

\section{cutting scheme for a large woodland}

(Quarter section or more)

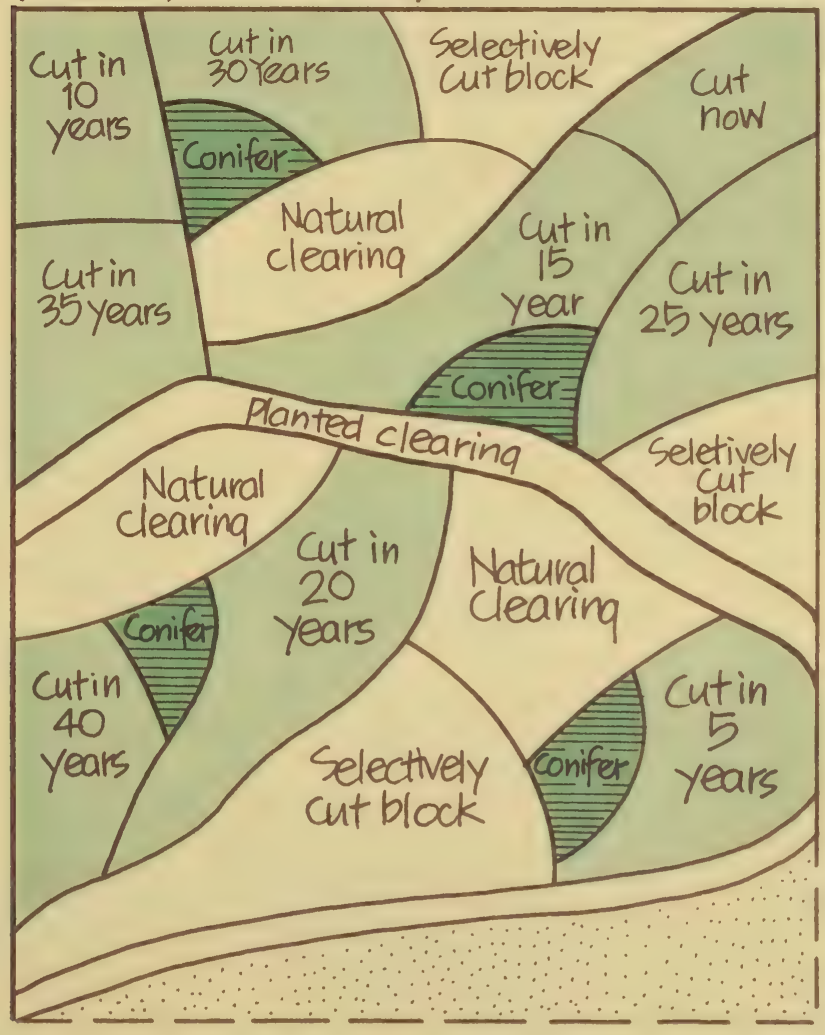




\section{Seed}

\section{Woodland \\ Openings}

Plant grasses and legumes in clearings to prevent soil erosion. Portions of these clearings can be seeded to food plots such as oats, barley and legumes. Seeding slows succession by creating a thick grassy sod which inhibits growth of woody plants.

Herbaceous openings provide variety, an important feature of good wildlife habitat. The plants supply food for deer and grouse and good nesting areas for a variety of birds. Low vegetation provides food for small rodents which, in turn, make good eating for coyotes, foxes, hawks and owls. Grouse chicks and songbirds feast on grasshoppers and other insects that thrive in grasses.

To seed openings, cultivate the soil lightly with a disc or similar implement. Broadcast the seed, then harrow and pack the soil. Be sure to use a grass-legume mixture recommended for your particular area or site. (See the table below.)

\section{Suggested Grass-Legume Mixtures to Reclaim}

Disturbed Sites and Improve Wildlife Habitat

\begin{tabular}{cc} 
Grass Mixtures & $\begin{array}{c}\text { Seeding } \\
\text { Rate Adaptation }\end{array}$ \\
\hline pounds $/$ acre
\end{tabular}

1. Alsike Clover

(Kilograms/ hectare)

Reed canary grass

Timothy

2. Alsike clover

Reed canarygrass

3. Alfalfa

Timothy

Brome or Pubescent

Wheatgrass

4. Alfalfa

Brome or Pubescent

Wheatgrass

Crested Wheatgrass

5. Alfalfa

Bromegrass

Creeping red fescue

6. Crested Wheatgrass or Russian Wildrye Alfalfa

7. Crested Wheatgrass or Russian Wildrye

Alfalfa

8. Sweet Clover

Alfalfa

Crested Wheatgrass *

Slender Wheatgrass

Intermediate Wheatgrass
Areas subject to prolonged flooding

For acidic soils subject to flooding.

Areas of plentiful moisture

Where moisture conditions are variable

For all but drier parts of province (prairies)

For moist to dry sites

6 5

\section{Driest sites}

This is our all-purpose recipe we use on Buck for Wildlife projects. It provides excellent nesting cover and high quality forage.
Improve Edges

Good land managers do not allow abrupt borders between woodlands and fields. They reduce competition between trees and crops for sunlight and moisture by cutting back the forest to encourage brush or shrub growth or by seeding a strip of grasslegume mix. Insect-eating birds such as tree swallows which help control crop pests flourish in uneven, diverse borders. A wide border of forage plants prevents weeds from invading fields where woods and fields meet.

Brushy woodland borders are especially attractive to farm wildlife. They provide travel and escape cover for ruffed grouse, rabbits and deer. They make good habitat for furbearers such as foxes, squirrels, mink and weasels. Low shrubby vegetation provides nesting sites for songbirds as well as protection from predators and harsh weather. Scattered brush piles make the edges even more attractive to wildlife.

\section{Retain Dead Trees}

A stand of dead or dying trees should be cleared to improve woodlot productivity. However, some trees such as poplar and spruce scattered throughout the woodlot are valuable to cavitydwelling wildlife and do not affect productivity. Trees bigger than 15 centimetres are excellent for cavity nesters. They provide nest sites for woodpeckers, chickadees, owls, bluebirds, wrens, tree swallows and purple martins.

Since most cavity nesting birds eat insects, they play an important role in controlling woodland pests. Squirrels also use dead trees for nests and food storage. Where dead trees are not available, nest boxes can be used. (See the chart in Fact Sheet 10 for hole sizes.) \\ - Substitute Tall wheatgrass in moist to wet areas.}




\section{Prevent \\ Livestock \\ Overgrazing}

Livestock cause severe

damage to woodlands by browsing seedlings and injuring saplings and tree roots with their hooves. They remove grass and herbaceous cover, exposing the soil to erosion and destroying habitat for ground nesting birds and small mammals. If cattle are fenced out, overgrazed woodlands recover dramatically in a year or two. Then, well-managed light grazing can be tolerated during the summer and can actually be beneficial.

\section{Manage Beaver Ponds}

Where beaver dams flood roads or valuable timber and agricultural areas, water levels can be controlled with the use of perforated culverts or floating electric fences. Both prevent ambitious beaver from repairing breaks in dams. For more information, contact your nearest fish and wildlife office.

\section{Perforated Culverts}

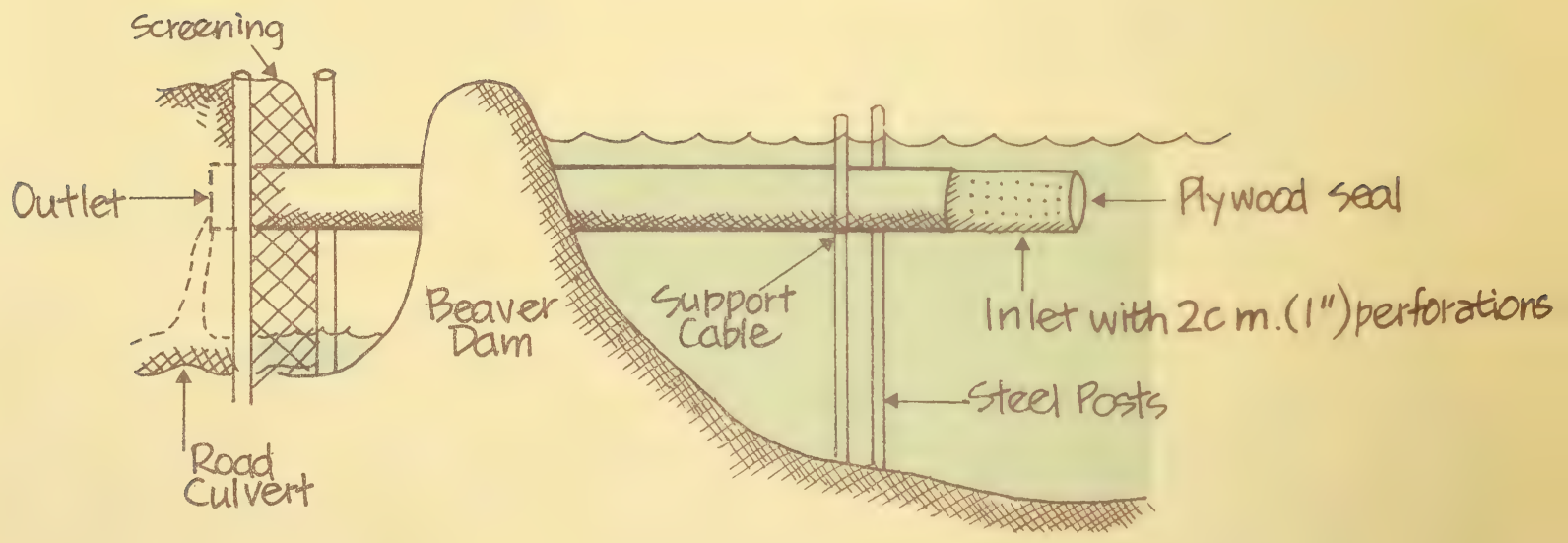




\section{Cover and Border Planting}

Cover crops are used mainly to control soil drifting. Fields with high wind erosion risk can be planted in permanent grass-alfalfa cover. Winter wheat and rye planted in late summer and harvested the following summer make an excellent cover crop. Legume-grass borders stabilize the soil at the field edge and provide a place to turn farm machinery.

Cover plants provide good winter protection and food sources. A narrow row of grain (about two metres) left standing near the cover provides an extra source of food for upland game birds, small birds and mammals.

\section{Protecting and} (n) Improving Odd Areas and Abandoned Farmsteads

Odd areas are patches of waste land such as rocky areas, field corners and gullies or old farmsteads no longer under cultivation. They may have little value for crops and livestock but they mean a lot to wildlife. These areas should be protected from fire and grazing. A living fence of thorny shrubs like caragana or rose may keep livestock out. At the same time, the fence offers cover to upland birds.

Odd fields and abandoned farmsteads provide good wildlife habitat. Those taken over by shrubs, small trees, grasses and forbs enjoy much wildlife use. Planting clumps of shrubs in odd fields improves their wildlife value. Old shelterbelts and windbreaks should never be removed as they provide valuable travel lanes to wildlife.

\section{A clump of evergreens planted} in the centre of a rocky outcrop or bare knoll provides good winter cover for wildlife. Brush or straw added to rockpiles makes good emergency food and winter cover.

Odd sites such as seep areas and plots with soil salinity problems provide good wildlife habitat when seeded to salt and water tolerant grasses, legumes, trees and shrubs. Be sure to preserve and encourage cattail and willow growth. 


\section{Favorite \\ Wildlife Trees \& Shrubs}

\begin{tabular}{ll}
\hline SPECIES & GROWTH HABITS \\
\hline Pin Cherry & $\begin{array}{l}\text { Small tree, } 3 \text { to } 10 \text { metres. } \\
\text { Autumn color yellow to orange } \\
\text { red. Broad, tall shrub; profuse } \\
\text { flowers followed by persistent } \\
\text { tiny berries. }\end{array}$
\end{tabular}

\begin{tabular}{|c|c|c|c|}
\hline $\begin{array}{l}\text { Siberian } \\
\text { Crabapple }\end{array}$ & $\begin{array}{l}\text { Deciduous tree to } 16 \text { metres. } \\
\text { Autumn color yellow to red. } \\
\text { Small fruit persistent to March. }\end{array}$ & $\begin{array}{l}\text { Fruit eaten by } \\
\text { many species. } \\
\text { Frequent nest } \\
\text { site. }\end{array}$ & $\begin{array}{l}\text { Best in full sun. Tolerates wide } \\
\text { variety of soils including mildly } \\
\text { acidic or alkaline. }\end{array}$ \\
\hline $\begin{array}{l}\text { Juneberry, } \\
\text { Saskatoon } \\
\text { Berry }\end{array}$ & $\begin{array}{l}\text { Small deciduous tree or shrub } \\
3 \text { to } 13 \text { metres. Autumn color } \\
\text { yellow, red. Edible fruit } \\
\text { June-August. }\end{array}$ & $\begin{array}{l}\text { Valuable food } \\
\text { source. }\end{array}$ & $\begin{array}{l}\text { Often found in lowlands. Tolerates } \\
\text { variety of soils and exposure. Sun } \\
\text { or partial shade. }\end{array}$ \\
\hline $\begin{array}{l}\text { Manitoba } \\
\text { Maple }\end{array}$ & $\begin{array}{l}\text { Deciduous tree to } 13 \text { metres. } \\
\text { Autumn color yellow, orange, } \\
\text { red. Fast growth. Seeds persistent } \\
\text { to spring. Hardy, long-lived. }\end{array}$ & $\begin{array}{l}\text { Important winter } \\
\text { food for evening } \\
\text { grosbeak. Nest } \\
\text { site for many } \\
\text { species. }\end{array}$ & $\begin{array}{l}\text { Prefers full sun and rich, moist } \\
\text { soil. }\end{array}$ \\
\hline Mountain Ash & $\begin{array}{l}\text { Deciduous tree to } 13 \text { metres. } \\
\text { Autumn color orange-red. Fast } \\
\text { growth. Red-orange fruit } \\
\text { August-March. }\end{array}$ & $\begin{array}{l}\text { Good fall and } \\
\text { winter food. }\end{array}$ & $\begin{array}{l}\text { Requires sun: prefers moist, } \\
\text { acidic soil. }\end{array}$ \\
\hline Paper Birch & $\begin{array}{l}\text { Decidous tree to } 25 \text { metres. } \\
\text { Autumn color golden yellow. } \\
\text { Rapid growth. Small cones } \\
\text { August to winter. }\end{array}$ & $\begin{array}{l}\text { Good winter } \\
\text { food for many } \\
\text { species: essential } \\
\text { for ruffed grouse. } \\
\text { Small cones } \\
\text { August to winter. }\end{array}$ & $\begin{array}{l}\text { Fine display in groups. Needs cool } \\
\text { moist area in sun or partial shade. }\end{array}$ \\
\hline Spruce & $\begin{array}{l}\text { Striking conifer, } 20 \text { to } 30 \text { metres. } \\
\text { Green to bluish needles. Mature } \\
\text { tree produces good annual crop } \\
\text { of cones Sept. through winter } \\
\text { at } 15 \text { years. }\end{array}$ & $\begin{array}{l}\text { Important for } \\
\text { food, cover and } \\
\text { nest sites. }\end{array}$ & $\begin{array}{l}\text { Highly desirable as lawn specimen } \\
\text { or in groups. Prefers full sun or } \\
\text { partial shade in acidic soil. }\end{array}$ \\
\hline Alder & $\begin{array}{l}\text { Deciduous tree to } 8 \text { metres. } \\
\text { Autumn color green to } \\
\text { brown. Cones Sept. to Dec. }\end{array}$ & $\begin{array}{l}\text { Preferred food } \\
\text { of goldfinch } \\
\text { and red poll. } \\
\text { Frequent cover } \\
\text { and nest site. }\end{array}$ & $\begin{array}{l}\text { Useful for stream margins or } \\
\text { wet banks. Cold tolerant. } \\
\text { Thrives in areas in full sun } \\
\text { or partial shade. }\end{array}$ \\
\hline Chokecherry & $\begin{array}{l}\text { Small deciduous tree or } \\
\text { shrubs } 2 \text { to } 6 \text { metres. Autumn } \\
\text { color bronze to yellow. Black } \\
\text { berries persist till winter. }\end{array}$ & $\begin{array}{l}\text { Preferred food } \\
\text { of many } \\
\text { species }\end{array}$ & $\begin{array}{l}\text { Useful for small properties or } \\
\text { to outline boundaries. } \\
\text { Tolerates variety of soils. } \\
\text { Usually found along fences: does } \\
\text { well in sun or shade; easily } \\
\text { transplanted. }\end{array}$ \\
\hline Dogwood & $\begin{array}{l}\text { Deciduous shrub or small tree } \\
1 \text { to } 10 \text { metres. Highly decora- } \\
\text { tive, large variety. Grows } \\
\text { singly or in thickets. At- } \\
\text { tractive brilliant red stems } \\
\text { in winter }\end{array}$ & $\begin{array}{l}\text { Important food } \\
\text { and cover for } \\
\text { many species. }\end{array}$ & $\begin{array}{l}\text { Excellent for borders and } \\
\text { clumps. Tolerates sun or shade } \\
\text { Preferes rich, moist soil. }\end{array}$ \\
\hline
\end{tabular}

VALUE TO

WILDLIFE

aluable food Best in sun. Tolerates wide variety

tree $\quad$ of soils including mildly acidic or

alkaline. Useful in creating low tree layer. 


\begin{tabular}{|c|c|c|c|}
\hline SPECIES & GROWTH HABITS & $\begin{array}{l}\text { VALUE TO } \\
\text { WILDLIFE }\end{array}$ & PLANTING LOCATION \\
\hline Elderberry & $\begin{array}{l}\text { Deciduous shrub } 1 \text { to } 4 \\
\text { metres. Juicy edible fruit. Can } \\
\text { be grown from cuttings. } \\
\text { Showy red berries July to } \\
\text { Sept. Autumn color yellow. }\end{array}$ & $\begin{array}{l}\text { Provides food } \\
\text { cover and nest } \\
\text { sites. }\end{array}$ & $\begin{array}{l}\text { Attractive in clumps or hedges. } \\
\text { Best in full sun in wide range } \\
\text { of soil. }\end{array}$ \\
\hline Juniper & $\begin{array}{l}\text { Common evergreen shrub to } \\
2 \text { metres, spreading to } 4 \\
\text { metres. Berrylike cones take } \\
2 \text { years to mature. When } \\
\text { selecting spreading junipers } \\
\text { from a nursery, be sure to buy } \\
\text { both male and female plants } \\
\text { (at least one should have fruit). }\end{array}$ & $\begin{array}{l}\text { Provides food } \\
\text { and cover for } \\
\text { many birds. }\end{array}$ & $\begin{array}{l}\text { Tolerates poor soil and wind; } \\
\text { excellent for sandy waste } \\
\text { places; grows well on } \\
\text { embankments. }\end{array}$ \\
\hline Roses & $\begin{array}{l}\text { Low, rounded or spreading } \\
\text { thorny shrub. Attractive and } \\
\text { durable. Various colors. Long- } \\
\text { blooming. Resists drought, } \\
\text { cold and salt. Flowers May to } \\
\text { Aug. Fruit July through } \\
\text { winter. }\end{array}$ & $\begin{array}{l}\text { Seeds valuable } \\
\text { winter food. } \\
\text { Frequent } \\
\text { nest site. }\end{array}$ & $\begin{array}{l}\text { Excellent for hedgerows and } \\
\text { clumps. Tolerates wide variety } \\
\text { of soils in full sun. Plant where } \\
\text { it can grow wild. }\end{array}$ \\
\hline $\begin{array}{l}\text { Russian } \\
\text { Olive }\end{array}$ & $\begin{array}{l}\text { Deciduous and evergreen. } \\
\text { Attractive landscape speci- } \\
\text { men. Fast growth. Fruit } \\
\text { Sept. to spring. }\end{array}$ & $\begin{array}{l}\text { Provides food } \\
\text { and cover for } \\
\text { many birds. }\end{array}$ & $\begin{array}{l}\text { Useful for windbreaks, snow } \\
\text { traps, hedgerows, or poor soil } \\
\text { sites. Tolerates adverse soil } \\
\text { conditions, heat, wind, salt and } \\
\text { drought. Prefers full sun. }\end{array}$ \\
\hline Viburnum & $\begin{array}{l}\text { Deciduous shrub } 2 \text { to } 6 \\
\text { metres. Autumn color red. } \\
\text { Withstands heavy pruning. } \\
\text { Easily transplanted. Rapid } \\
\text { growth. }\end{array}$ & $\begin{array}{l}\text { Important food } \\
\text { during fall mi- } \\
\text { grations, winter } \\
\text { food, cover and } \\
\text { nest sites. }\end{array}$ & $\begin{array}{l}\text { Attractive alone or in clumps. } \\
\text { Variety of soils in shade or } \\
\text { sun. }\end{array}$ \\
\hline Bearberry & $\begin{array}{l}\text { Evergreen ground cover spread- } \\
\text { ing to } 5 \text { metres. Roots as it } \\
\text { creeps. Red berries July to } \\
\text { March. }\end{array}$ & $\begin{array}{l}\text { Provides food for } \\
\text { many species in- } \\
\text { cluding ruby- } \\
\text { throated hum- } \\
\text { mingbird. }\end{array}$ & $\begin{array}{l}\text { Useful in preventing erosion in } \\
\text { low slopes. Prefers sandy or poor } \\
\text { soil in sun or partial shade; with- } \\
\text { stands extreme cold. }\end{array}$ \\
\hline Bittersweet & $\begin{array}{l}\text { Deciduous climbing vine to } 6 \\
\text { metres. Autumn color yellow. } \\
\text { Yellow-orange fruit Aug. to } \\
\text { Jan. Male and female plants should } \\
\text { be near each other to } \\
\text { cross pollinate. }\end{array}$ & $\begin{array}{l}\text { Frequent nest site } \\
\text { and food for } \\
\text { many species. }\end{array}$ & $\begin{array}{l}\text { Attractive on trellises or low walls. } \\
\text { Prefers drier sites in sun or } \\
\text { partial shade. }\end{array}$ \\
\hline Honeysuckle & $\begin{array}{l}\text { Vine or shrub to } 3 \text { metres. } \\
\text { Spreading } 2 \text { to } 3 \text { metres. } \\
\text { Autumn color yellow-green. } \\
\text { Hardy. Holds fruit till late fall. } \\
\text { Red berries June to Nov. Rapid } \\
\text { growth. Needs little care. }\end{array}$ & $\begin{array}{l}\text { Provides food, } \\
\text { cover and } \\
\text { nest sites. }\end{array}$ & $\begin{array}{l}\text { Effective alone or in clumps. } \\
\text { Thrives in moist soil in sun } \\
\text { or shade. }\end{array}$ \\
\hline
\end{tabular}

\footnotetext{
- This table adapted from The Landscaped Oasis by Ron Allensen, Harrousmith, June/July 1983.
} 


\section{Fencerows and Hedges}

Hedges or shrubby fencerows of caragana or rose help stop wind erosion. They also trap snow moisture and can be used as livestock fences.

For wildlife they provide food, cover and travel lanes. The wider these travel lanes are, the better. Fencerows can be widened by planting grass and legume mixtures on each side of the fence or by leaving strips uncultivated. Grassy strip cover should be burned or mowed every four to seven years during early spring or in the fall to prevent woody growth from taking over the grassy area.

\section{Zero Tillage}

Zero tillage or stubble seeding involves, as the name implies, no tilling. Crops are seeded directly into unprepared soil or stubble. A narrow slot is cut deep enough to cover the seed with moist soil. Weeds are controlled by using herbicides. Contact your district agriculturalist for more information on weed control.

Benefits of this technique include more stable soil moisture for crops, fewer soil salinity problems, less soil erosion and less surface water and drainage problems. More stable soil temperatures speed up germination and seeding stages. The land manager saves time by reducing the number of machines and operations required to plant crops.

Wildlife benefit from waste grain left on the fields over winter. The grain provides a good food source as well as cover to ground nesting birds such as mallards, pintails, pheasants and meadowlarks.

\section{Strip Farming}

Strip farming involves planting strips at right angles to prevailing winds to reduce wind erosion. This technique used extensively in southern and eastern portions of Alberta is an excellent means of controlling soil drifting. In areas of the province where corn is an important crop, strips of corn left standing over winter cut down on wind erosion. They also provide winter food sources for partridge, grouse, pheasants, deer and antelope.

Strip cropping adds variety by increasing the amount of edge. It can attract nearly twice as many upland wildlife species as undivided fields. This land use practice is especially helpful when used in conjunction with shelterbelts or cover plantings between the strips to increase the edge effect and provide continuous, unbroken habitat areas.

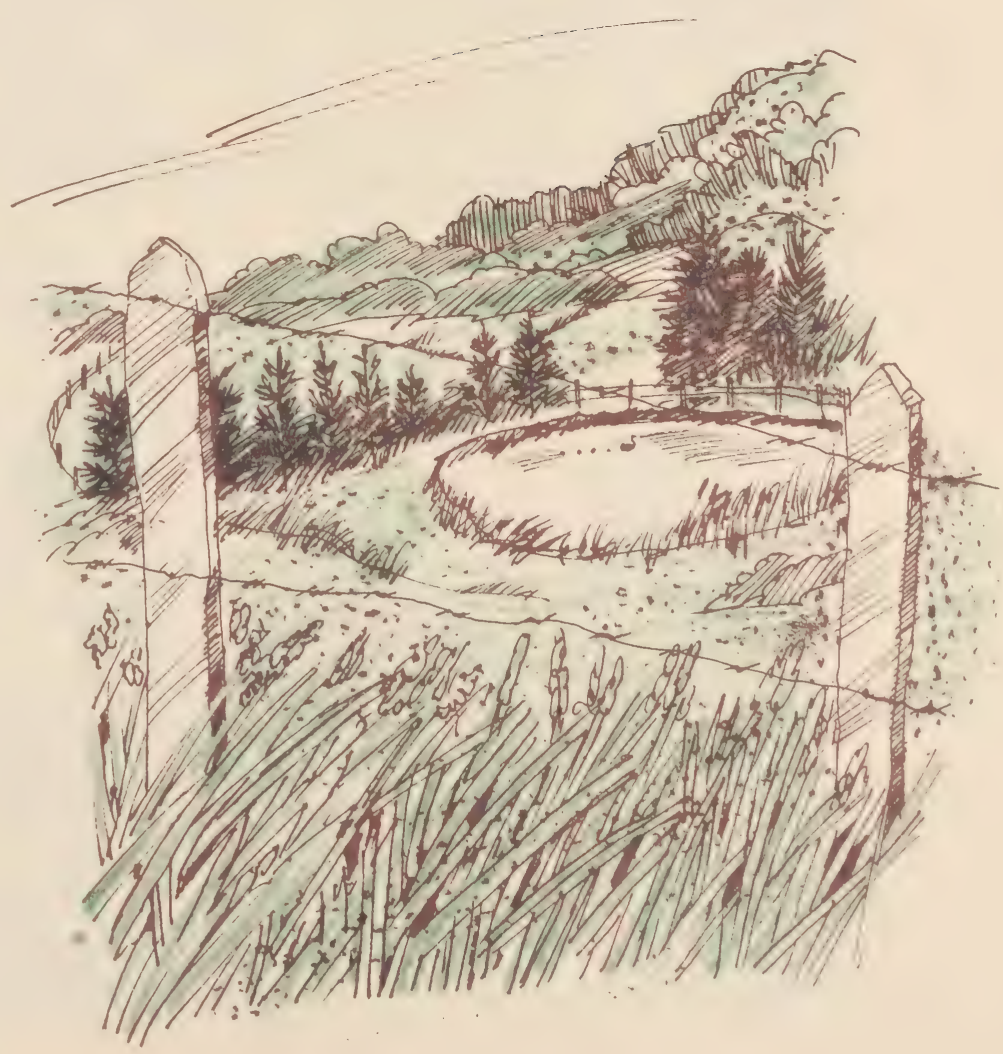




\section{Use Burning and Herbicides Carefully}

Burning stubble or crop residues to control weeds is of little benefit and can actually harm the land. It is wiser to cultivate residues back into the soil.

Burning cropland or wetland fringes can harm wildlife by removing protective cover and nesting sites provided by wetland plants, plant residue and woody brush. On the positive side burning releases nitrogen, phosphorous and potassium nutrients tied up in vegetation back into the soil. If burning is necessary, it should take place in early or mid-April as later burning destroys more nests.

Herbicides are expensive and can drift onto non-target areas such as crops or drinking water. Build-up of herbicides not only destroys food sources by killing plants and insects but can harm wildlife itself.

\section{Avoid Early Tillage, Late Ploughing}

Summerfallow is often tilled early in the spring. If left until later, then cultivated twice, the farmer sometimes avoids another tillage without loss of soil water or increase in weed problems. Fall ploughing should be avoided because it exposes the soil to moisture loss and wind erosion.

Often land is cultivated during peak nesting times and many nests are destroyed. By delaying cultivation until spring, waste grain and standing stubble provide winter food and shelter for birds.

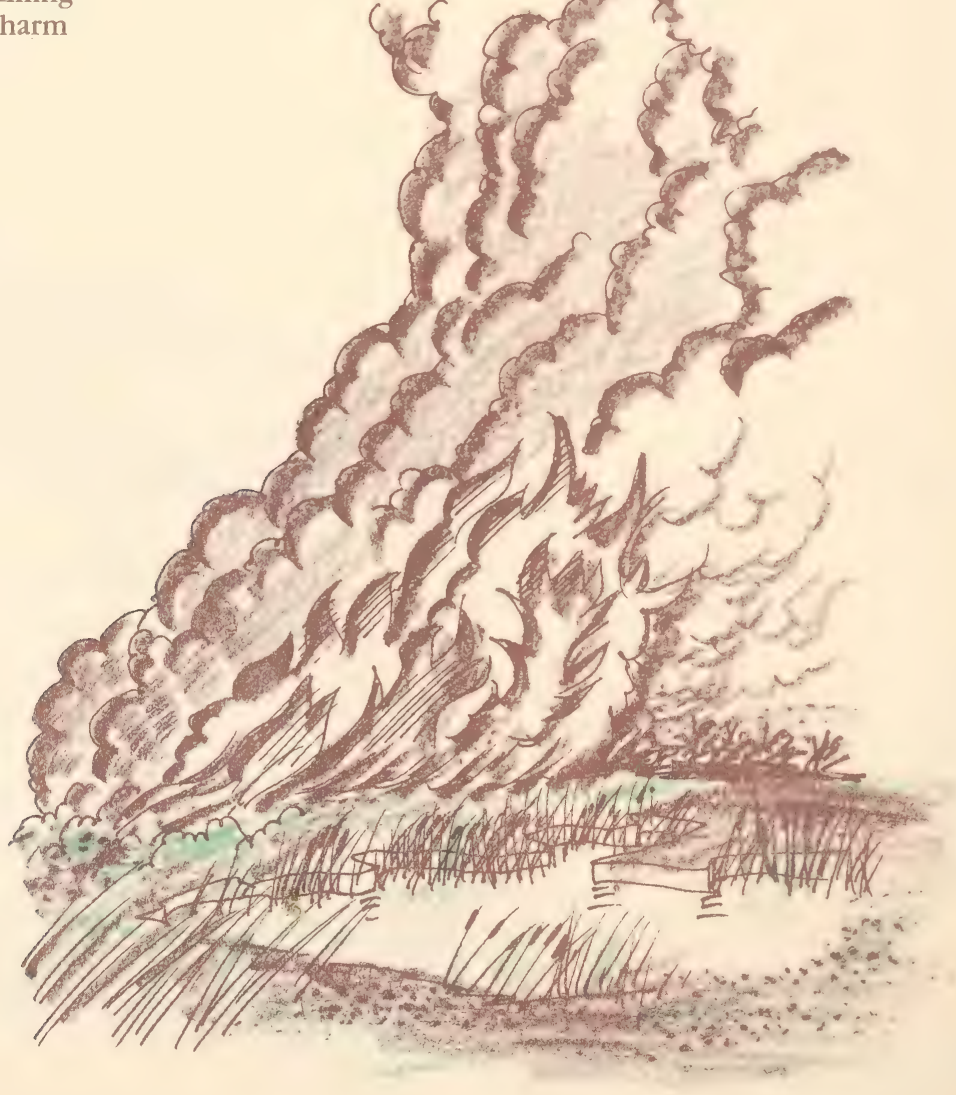




\section{Fact Sheet 8}

Rangelands

Rangelands are uncultivated areas that support herbaceous or shrubby plants. Less fertile than croplands, they are usually used for grazing and forage production. Four kinds of rangeland are found in Alberta: mixed grass prairie, fescue grassland, parkland and bush pasture.

The main vegetation types making up mixed grass prairie rangeland are needle and thread, blue grama grass and wheatgrass.

Fescue grassland is characterized by plenty of rough fescue. In this region, only the stony, sandy, hilly portions are grazed while the rest of the land is farmed.
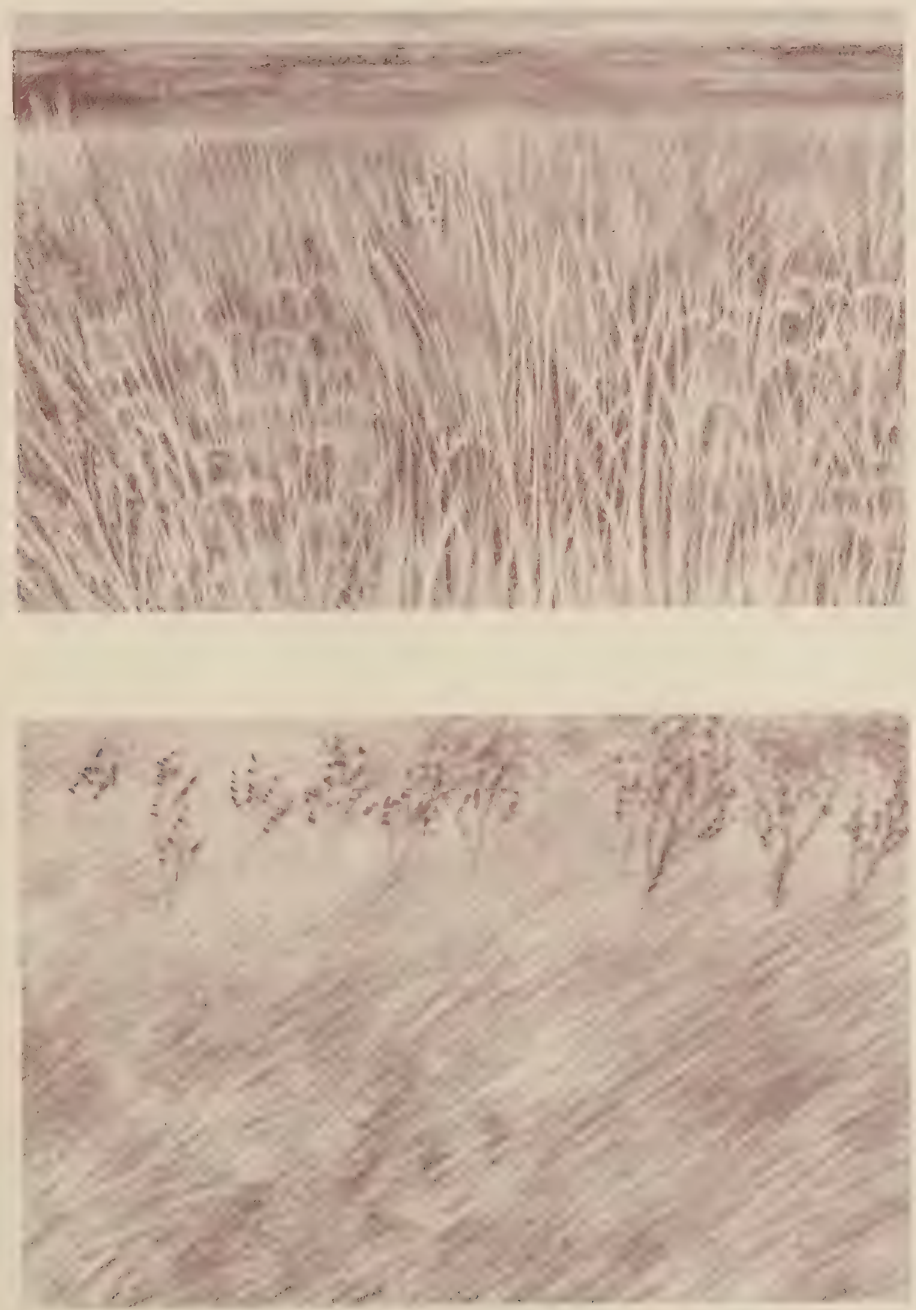
The northern part of the parkland is mostly forest with occasional patches of grassland. The southern part is mostly grassland with occasional groves of aspen.

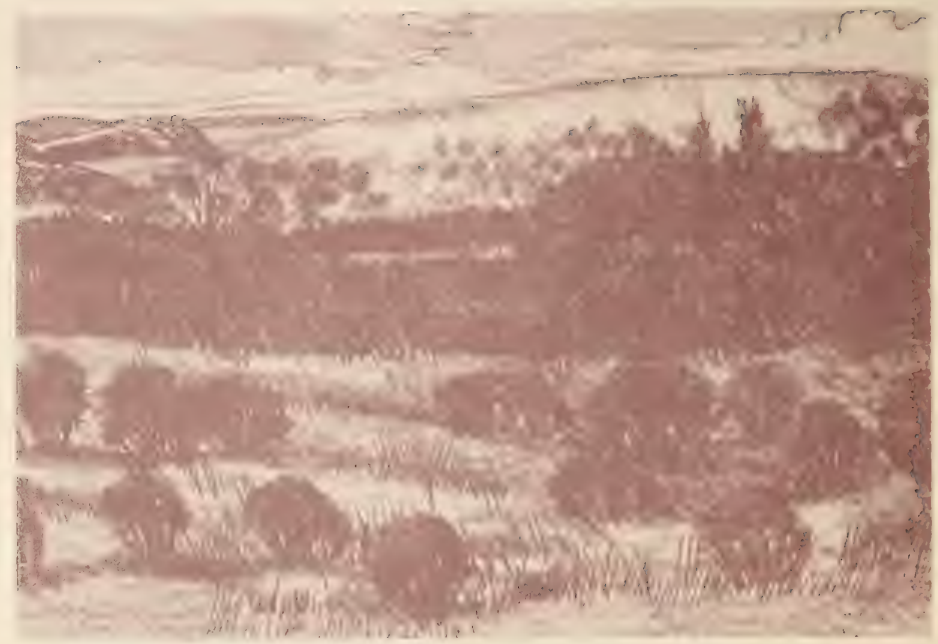

Bush pastures include the forested areas of the parkland and sub-boreal forest north of the North Saskatchewan River. The grazing season is short. Grazing must be light as grasses and other forage plants do not withstand heavy use.

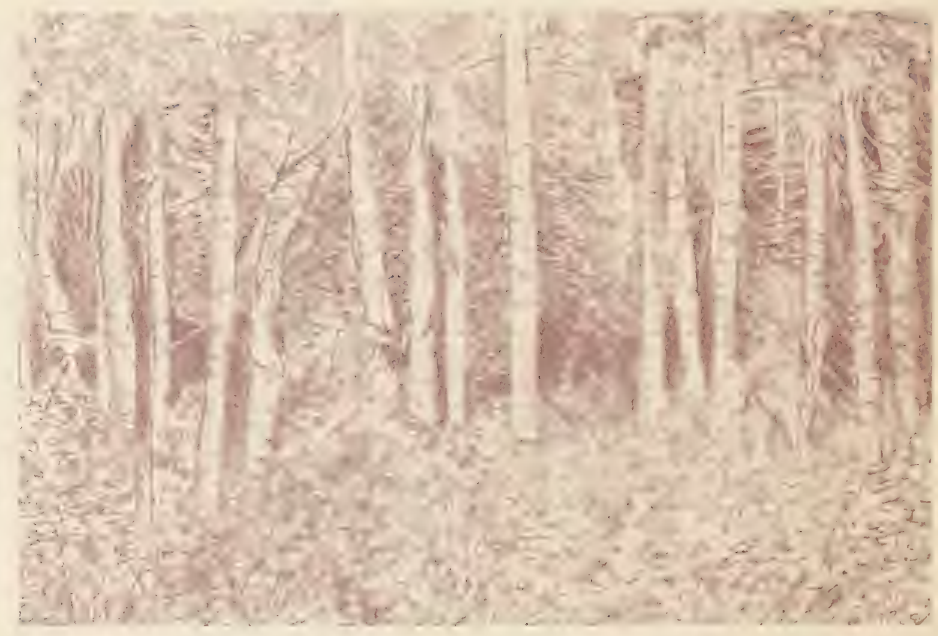

\section{Importance of Rangelands}

Rangelands are important to the production of livestock. Often rangeland forage is combined with crop residues to feed livestock, making good use of crops that might otherwise go to waste.

Rangelands provide important habitat for many big game animals. Songbirds, upland game birds, waterfowl and fish also make their homes in rangeland areas.

Pronghorn antelope, ferruginous hawks and burrowing owls require broad expanses of native grassland for their survival. 


\section{Fact Sheet 9}

\section{Protecting and Enhancing Rangeland Habitat}

\section{Grazing \\ Management}

Livestock and wildlife can share the same habitat as long as neither threaten the health of the range. Good range management is needed to make sure the carrying capacity of the range is not exceeded. Overgrazed ranges are invaded by thistles, silverberry, sage, and cacti such as prickly pear, making them unfit for both cattle and wildlife. Excessive stocking also causes soil erosion and loss of soil fertility. Soil erosion can damage the range to such an extent that even long periods of rest from grazing cannot restore it to its original condition.

Good grazing management attracts helpful birds that eat insects and weed seeds. It discourages less desirable wildlife such as Richardson's ground squirrels and badgers which thrive on overgrazed pasture and rangeland. Ground nesting ducks and songbirds can be attracted to a particular field by arranging a grazing schedule which leaves lots of cover in the spring. Livestock grazing can improve the quality of winter forage for elk or deer when the rate of cattle stocking is light enough to leave forage on all pastures at the end of the cattle grazing season.
Simple grazing involves spreading animals evenly over the range, balancing their numbers with available forage. A good range manager considers the growth of range plants and allows grazing only at certain stages of the plants' development.

Each of the following systems - rotation, rest-rotation and deferred - offers benefits over non-stop season-long grazing.

In a rotation system, divide the range into fields or pastures. Graze each, one after another. Move the livestock from pasture to pasture so more than one field receives a rest or several rests in the same year. Base the season of rest on the needs of the grasses rather than on a pre-determined number of months. Several long rests usually encourage the most desirable range plants. Increase the number of fences to divide up pastures into a number of units Try not to use standard barbed wire as it may prevent movement of Pronghorn antelope resulting in more winter deaths for these animals. (See diagram)

Rest-rotation involves resting a portion of a pasture for an entire growing season. Although

livestock numbers may have to be cut at first, stocking rates should increase as the range improves. Fields are not harmed by grazing during the dormant season.

Rotational grazing systems provide a number of advantages to wildlife. Part of the grazing area remains undisturbed and provides more favorable feeding, nesting and resting habitat for wildlife species. Grazing by cattle may stimulate the growth of preferred wildlife food plants

By keeping a thick, deeplyrooted grass cover, rest-rotation reduces erosion and soil compaction, helps prevent weeds and promotes a better variety of forage grasses

A deferred grazing system delays grazing on part of the range until after seed maturity. The longer grazing is delayed, the better the opportunity for new plants to establish themselves and old plants to gain vigor. If carrying capacity on the rest of the range is exceeded, the benefit to the deferred pasture is lost. Unlike the other two systems, this system does not interfere with livestock production. Seeded forages can take more grazing than native grasses therefore stocking rates on seeded pastures can be higher. On native pastures 45 per cent or more of native forage should be

\section{Rest rotational qrazing}

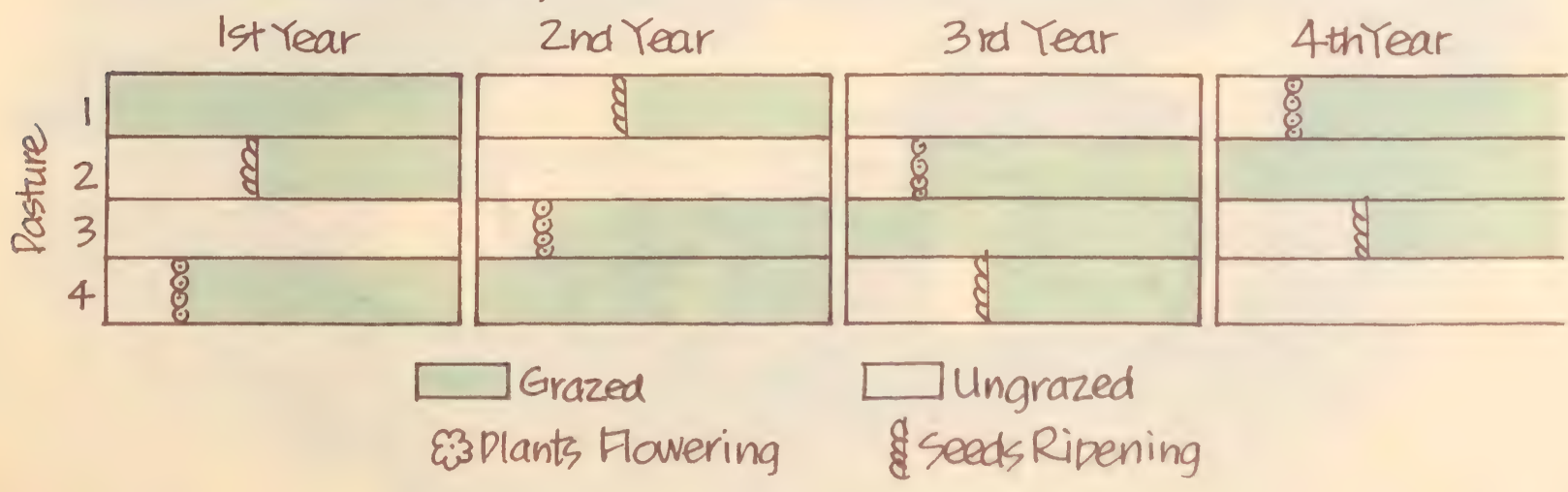


left. Less can be left on seeded pastures. Native rangelands should not be grazed until after June 15 for fescue grasslands and late May for mixed grass prairie.

These suggestions are general and may vary according to weather, soils, vegetation and location of your area.
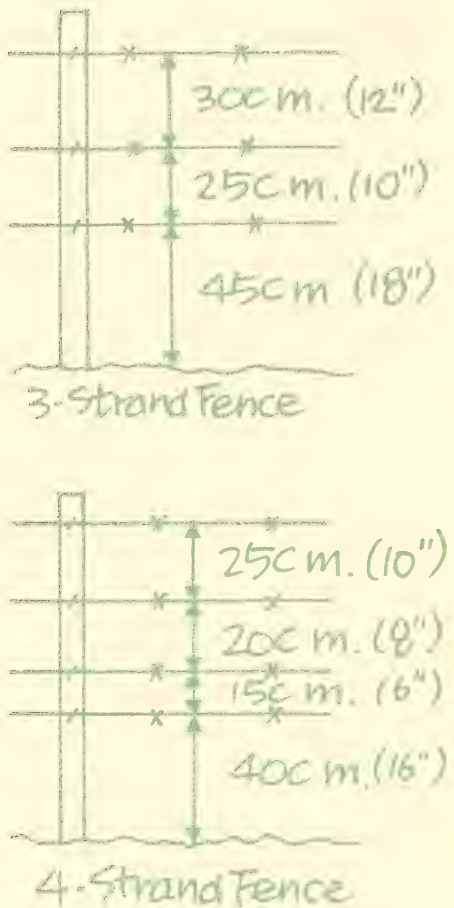

\section{Fencing which does not restrict antelope movement}

\section{Retain Brush and Shrubs}

Brush and shrubs add to good land management even though a large amount of brush cover reduces forage production, increases livestock handling costs and hampers range improvement efforts. Shrubby patches may offer livestock shade and protection. Brush species like silver willow are nitrogen-fixers and in low to moderate numbers improve soil fertility and productivity for desireable native grass species. Moderate brush grazing stops the spread of woody growth. Too much grazing, though, can cause invasion of undesireable shrubs and weeds. Retaining brush in sandy, rocky and low areas helps reduce soil erosion. required for the increased number of animals improved forage can carry

Water created from dugouts keeps livestock from entering marshy areas where they can become mired. You can locate and design dugouts and watering areas so they benefit wildlife, especially waterfowl, by developing dugouts near shallow marshes and away from busy roads and farmyards. Make them irregular in shape rather than square or rectangular. Creating dugouts for livestock use also leaves natural sloughs and marshes free for waterfowl and marsh bird use. Cattle do not trample aquatic vegetation or destroy nesting cover and nests if they are not constantly using the edge.

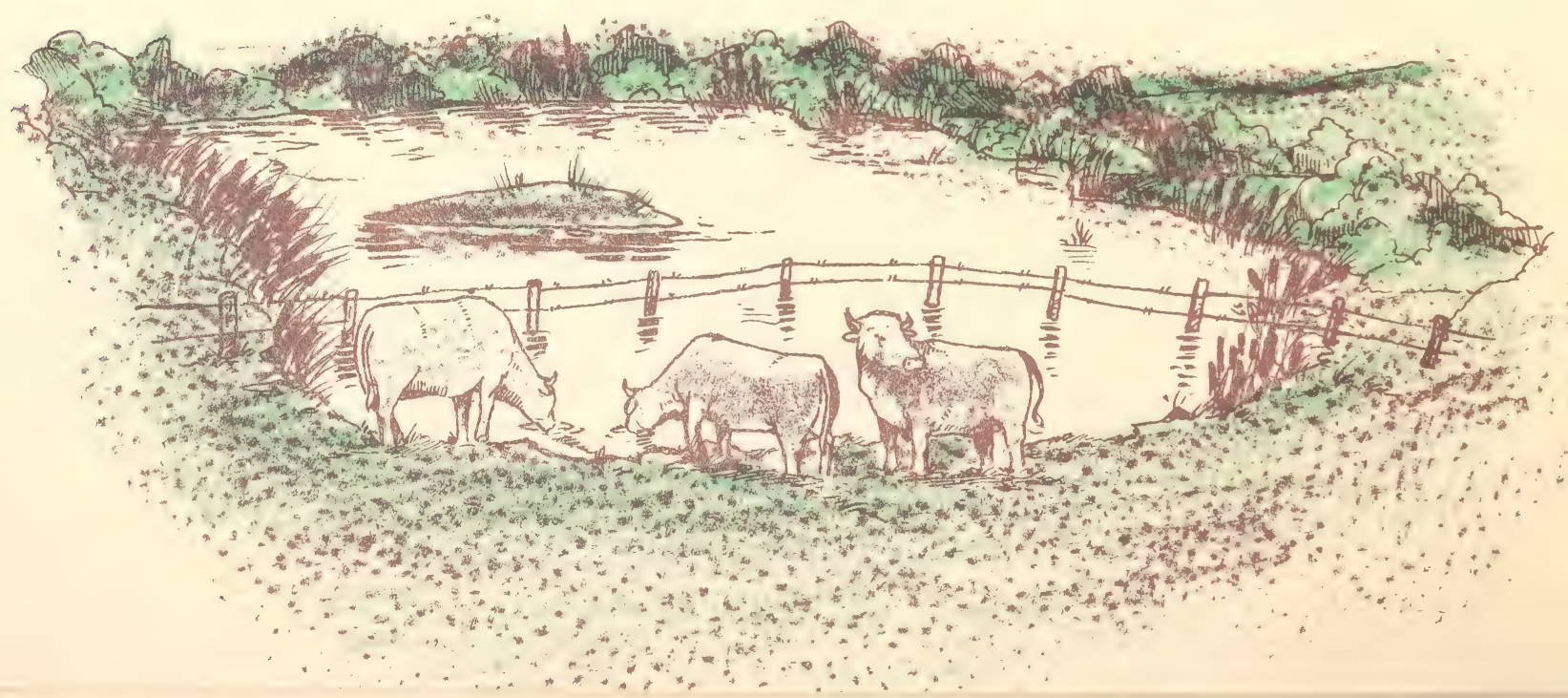




\section{Fact Sheet 10 \\ Wildlife in Your Backyard}

You do not often think of your backyard as a haven for wildlife but it can be with little effort. Chances are, there are already many species making their home there. Just like woodlands, wetlands and agricultural areas, backyards have distinct ecosystems complete with predator-prey relationships, territories, home ranges and carrying capacities.

\section{Importance of Backyard Habitat}

As in other ecosystems, the presence of wildlife indicates a healthy environment. Insects feed on plants and in return pollinate them. Insects also break down wastes, another important service to the environment. Honeybees, moths, butterflies, grasshoppers crickets, wasps, dragonflies and earthworms are just a few of the many insect species that make their homes in the backyard. These tasty morsels attract many kinds of birds, such as robins, orioles, nuthatches, field sparrows, and bluebirds. Chipmunks, squirrels, garter snakes and toads can also be found in backyard nooks and crannies. There are a number of things you can do to attract more wildlife. The size of your yard is your only restriction.

\section{Add Variety}

The more variety there is the better, but do not overcrowd Add variety by planting trees, flowers and shrubs. Thorn bushes like raspberry and rose provide cover as well as food. The cones of alder and birch trees provide food for seed-eating birds. Pine cones attract squirrels and blue jays. Mountain ash and wild cherry trees attract robins, western bluebirds and other birds. Keep larger trees and shrubs to border areas. If the yard is large, plant a clump of trees. Do not plant trees where they will shade gardens or other areas needing sun. (See the Favorite Wildlife Trees and Shrubs table in Fact Sheet 7 for more information.)

Hummingbirds and insects are attracted to flowers such as honeysuckles and elderberry. Annuals such as sunflowers, millet, asters, cosmos, zinnias, marigolds and bachelor's buttons attract seed eating birds.
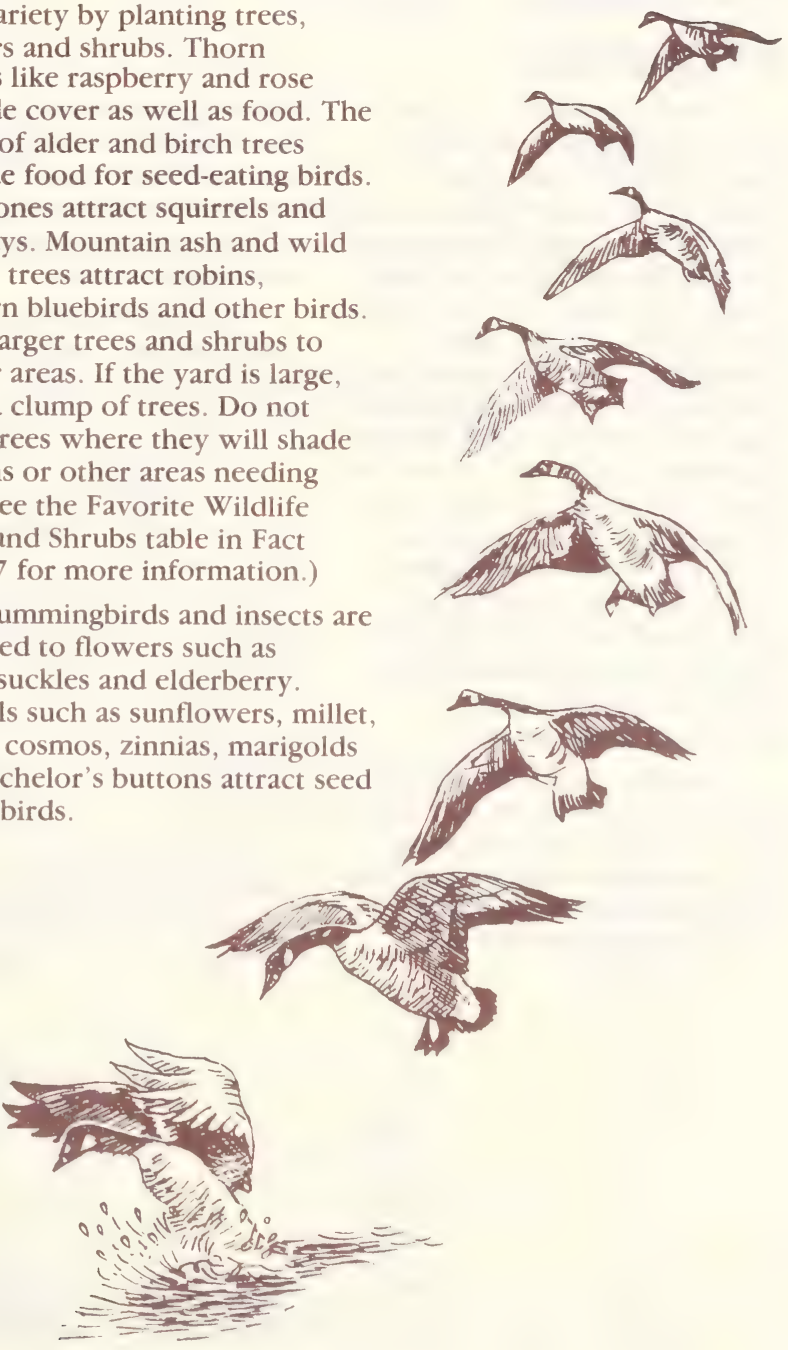


\section{Add a Water Source}

A source of water is important to attract birds to your backyard habitat. A bird bath or small pond can fill the bill as long as it has shallow areas (less than six centimetres).

Place your bird bath or pond in an open area with a cover planting of at least two metres to allow escape from predators.

\section{Start A Winter Feeding Program}

With little effort, you can enjoy entertainment all winter long from your bird "stage". During harsh winters, these bird feeders often mean the difference between life and death for many feathered friends. Once you begin a feeding program, it must continue all winter long and well into the spring, when insects and other food sources are available. Seed-eaters can be fed a variety of cereal grains such as millet, hemp, buckwheat, cracked corn and sunflower seeds. Seed mixtures can be added to foods high in protein and mineral content like meat scraps, ground dog biscuits, raisins, wild seeds, dried wild berries and melon seeds.

Bird feeders can be anything from a simple platform to a fancier feeder complete with hoppers, glass sides and weathervanes that keep the open side protected from wind. Platforms should have

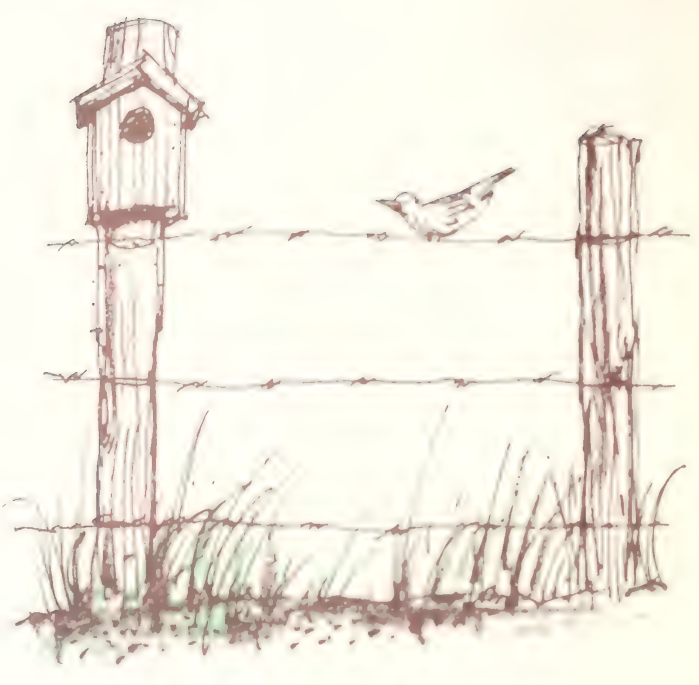

Build

Nest Boxes

raised edges to stop food from blowing off. Paint all glass and metal surfaces to prevent injury Roofs should provide shelter without preventing birds from escaping predators

Place the feeders in sheltered sunny locations out of reach of predators. Stucco wire and metal shields attached to the feeders prevent cats from intruding.

Suet and other beef and mutton fats offer high energy food sources to insect-eaters such as woodpeckers, chickadees, and nuthatches. Serve it in chunks or in seed cakes. To make a seed cake, grind the suet and melt it in a pan. Cool, then reheat it. Pour it into holes in a suet log containing bird seed and let it harden.

(Grapefruit or coconut shells can be used instead of logs.) Do not feed birds bread, pastry and other white flour products low in nutrients.
Vest boxes can be fancy but plans described here are simple and easy to build. Boxes must be strong. weatherproof and fastened securely. Roofs should be easy to remove for annual cleaning. The basic design of the bo $\mathrm{x}$ is the same for all species but size and location vary. The size of the box and the entrance hole is based on the size of the bird you wish to attract. Protect the hox from predators with an inverted cone or strip of metal around the tree or pole. Do not attach a platform or perch as predators use them to raid nests. Young birds also venture onto them before they can fly, frequently falling and hurting themselves. 


\section{Asimple Bluebird Birdhouse}

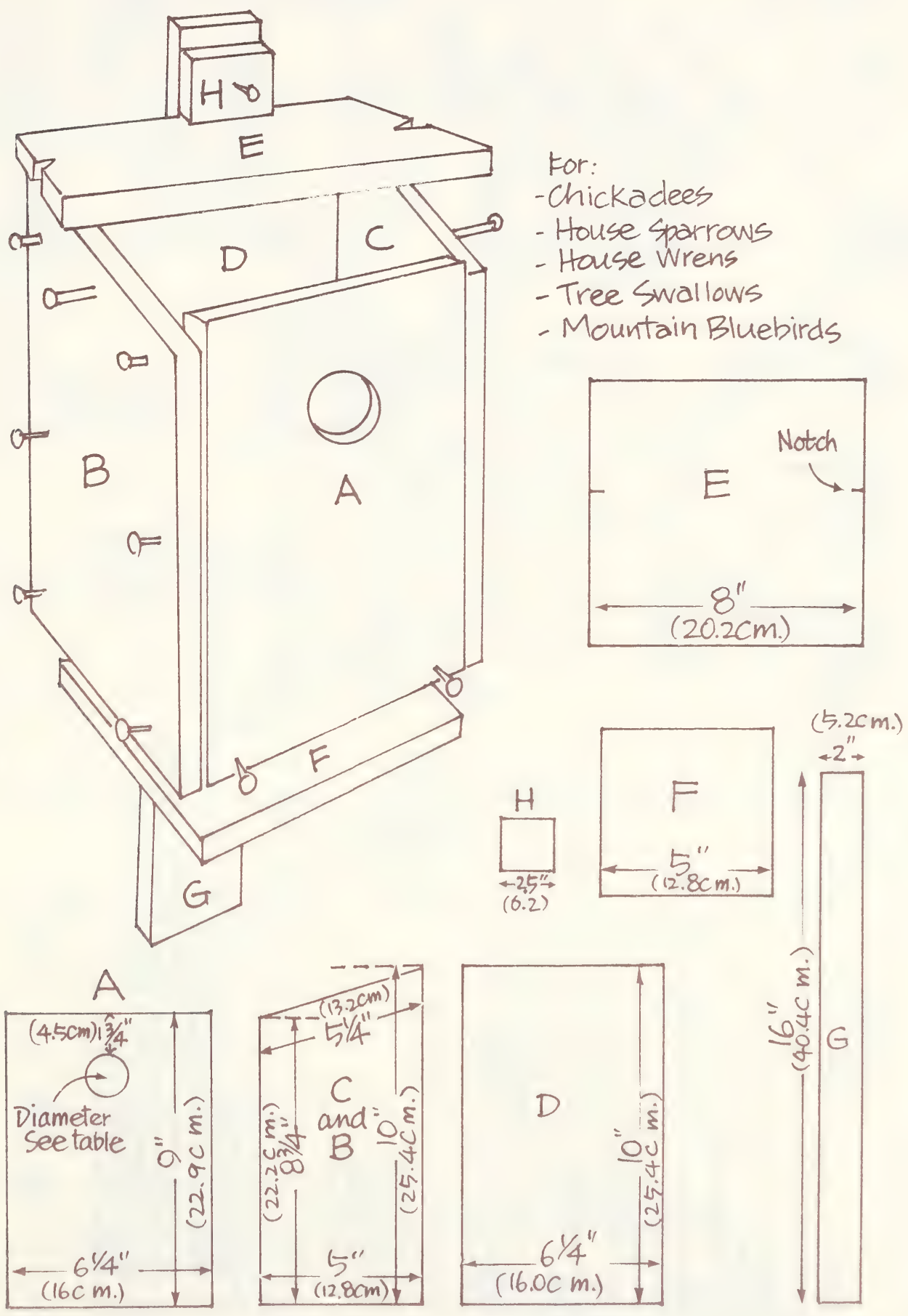




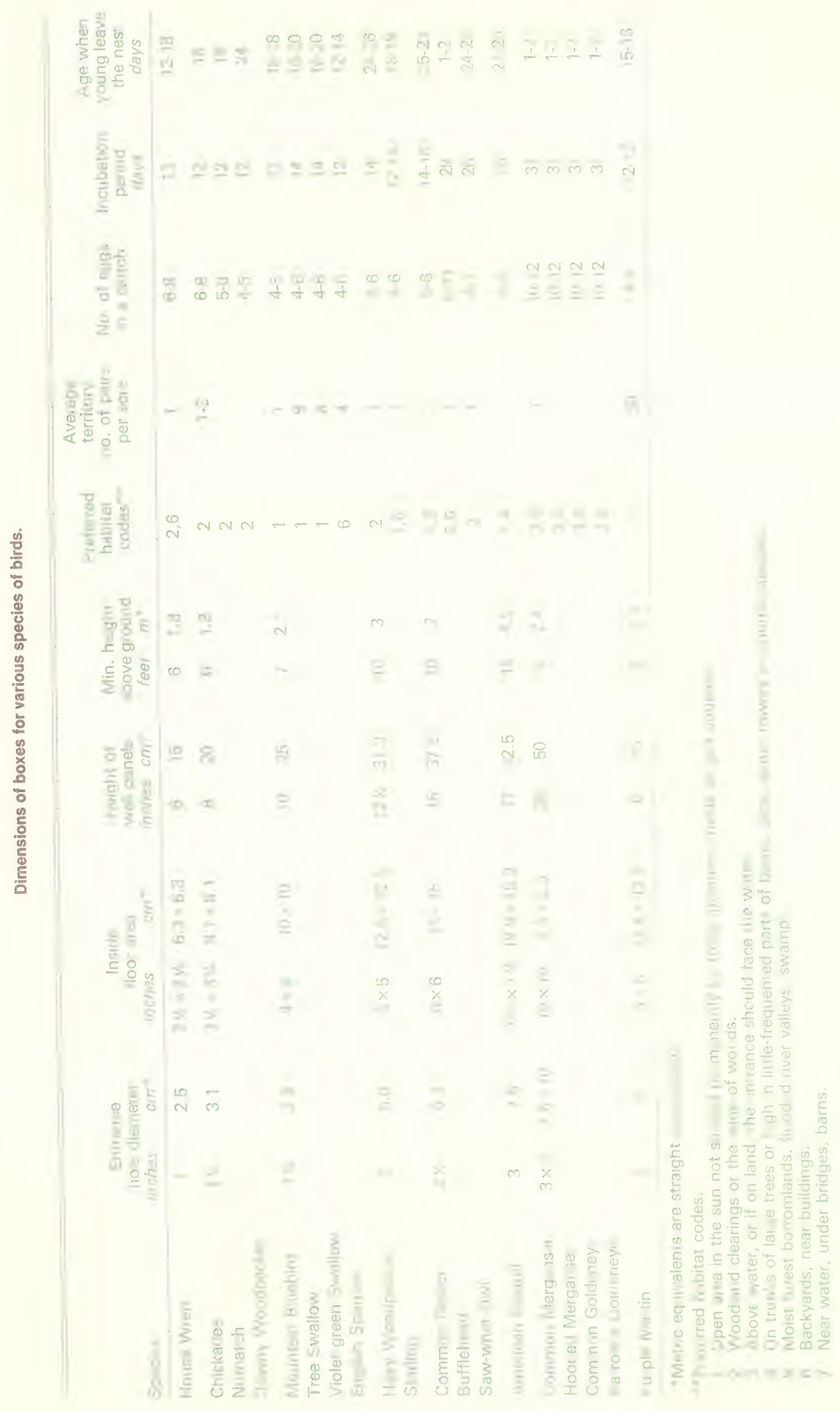


Backyard Enhanced for Wildlife

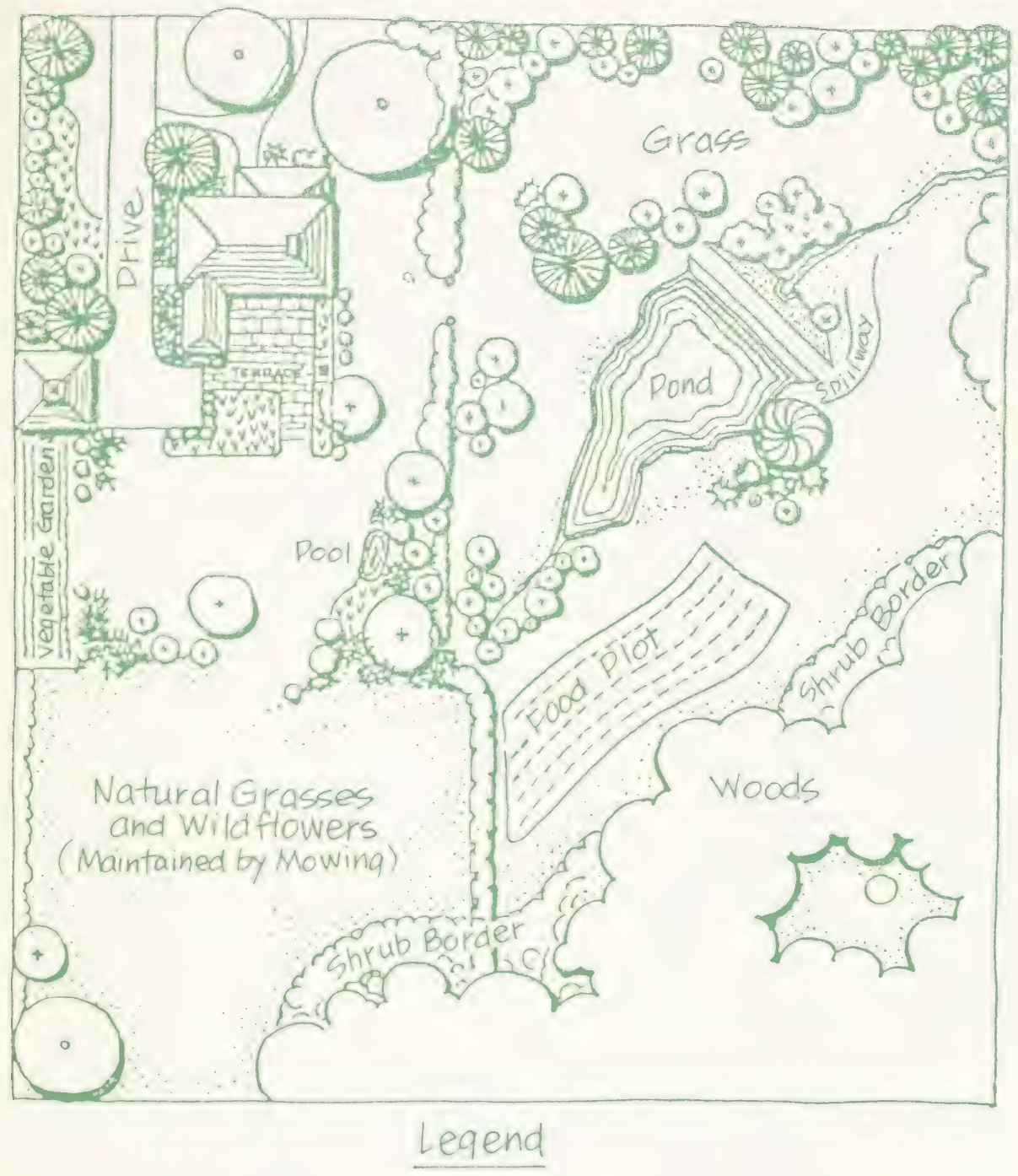

(3) Pond or Birdbath

Non Flowerbed

- Shade Tree

(4)Trees for Birds

cmins shrub Hedge

Large Conifer

58 Weeping Willow

O. Woodland Elearing

Low Conifer

- Ornamental or

Ener Natural or

(1) Shrubs for Birds

Conifer Screen with (iv) Planted ShrubBorders 
A Simple Birdfeeder.
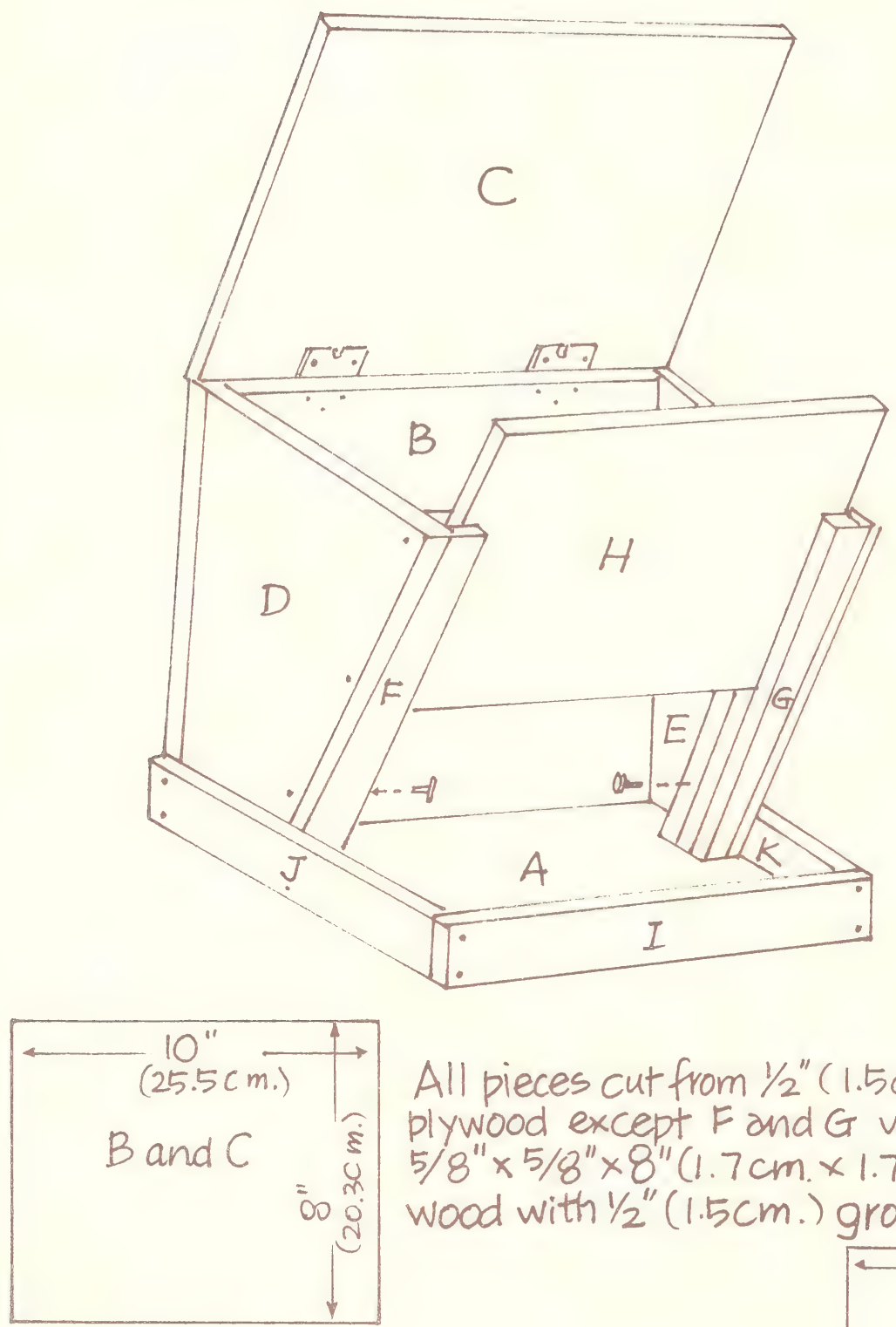

All pieces cut from $1 / 2^{\prime \prime}(1.5 \mathrm{~cm}$.)

plywood except $F$ and $G$ which are $5 / 8^{\prime \prime} \times 5 / 8^{\prime \prime} \times 8^{\prime \prime}(1.7 \mathrm{~cm} \times 1.7 \mathrm{~cm} \times 18 \mathrm{~cm}$. wood with $1 / 2$ " $(1.5 \mathrm{~cm}$.) groove.
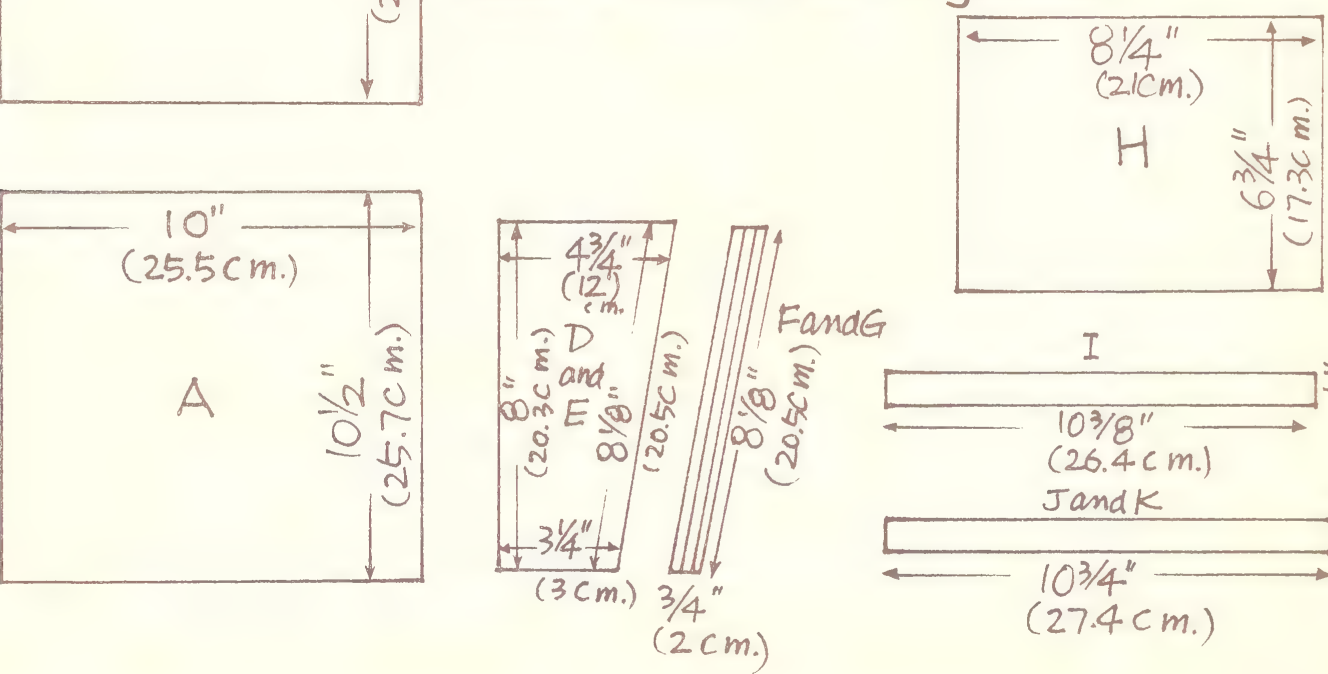

FandG

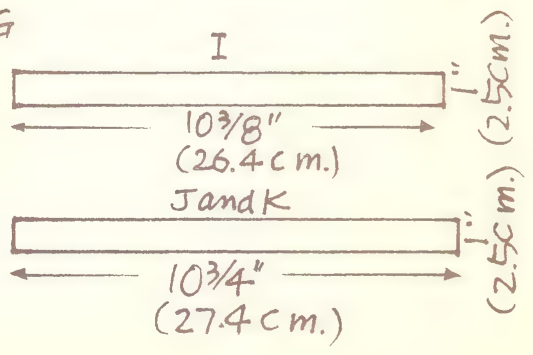




\section{Wildlife Damage Problems and Their Control}

TYPE OF DAMAGE

USUAL

FACTORS

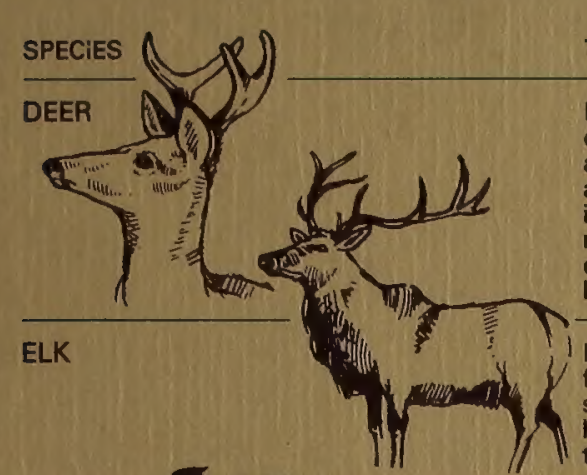

Browsing and antler damage to orchard and antler damage to orchard and forest trees; browsing field crops and ornamentals; livestock competition; and competition; and
highway hazard

Browsing of orchard and forest trees; grazing of standing and stacked hay; livestock competition

Pecking and eating corn plantings, tomatoes, berries, grapes

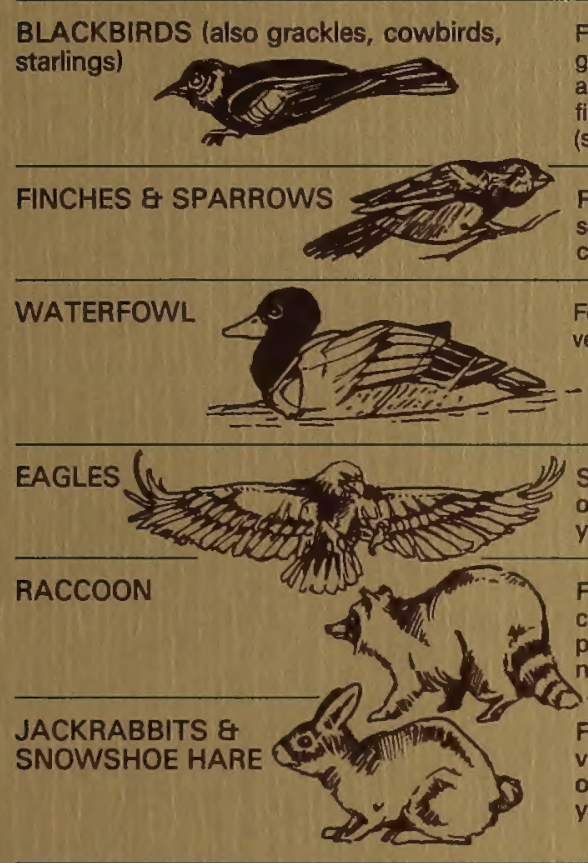

Feeding on corn, grains, grapes, sott fruits, and at feedlots; noise and filth at city roosts (starlings)

Feeding on fruit, planted seeds, disbudding of orchard trees

Feeding on corn, grains vegetables, pasture crops

\section{$-$}

Sporadic, isolated killing Sporadic, isolated killing young of big game

Feeds on corn, other crops, poultry, raids fish ponds, and is suburban nuisance

Feeding on forage and vegetable crops; girdling of young trees, vineyards, ornaments

\section{FIELD RODENTS, GOPHERS, MICE, GROUND SOUIRREIS

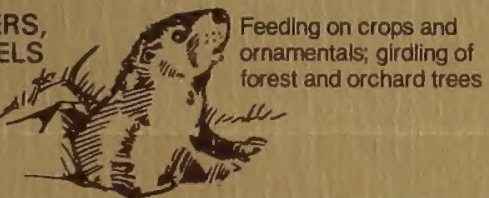

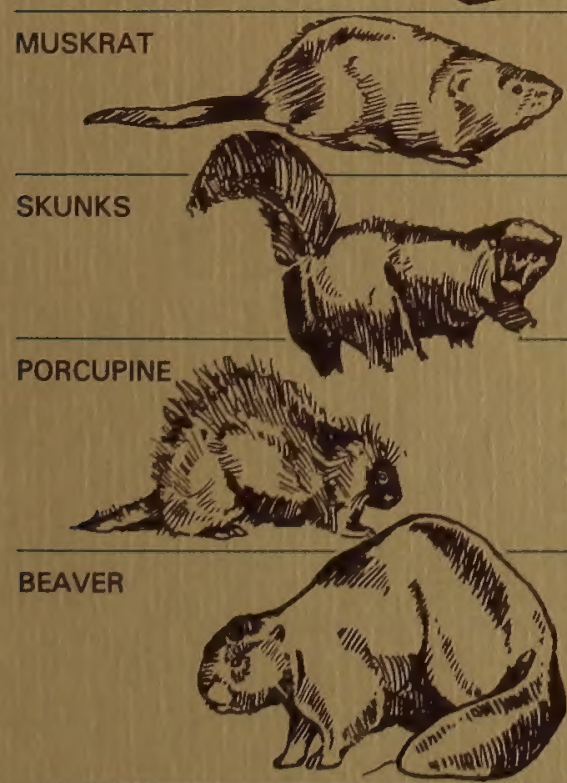

Burrow damage in levees and banks; crop damage. flooding and erosion are secondary ef fects

Public health hazard (rabies); poultry, game bird and turf damage odor nuisance

Girdling orchard and forest trees; gnawing buildings, equipment and signs; feeding on hay crops; livestock injury

\section{Tree cutting: riparlan} Tree curting: riparian softwoods, orchard, and ornamentals; dam builic ing may obstruct water structures, flood roads and meadows, create washout hazards, affect flsh habitat

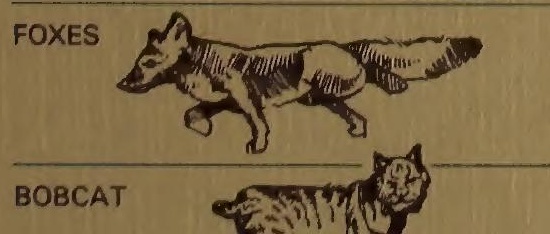

Poultry and game bird depredation; rabies car rier sprouting grains by geese

Persistent, year-round atspread; cyclic pattern
Orchard, forest, and vineyard damage may be year-round with resident deer; migratory herds and annual crops are seasonal factors

Seasonal damage in migratory patterns; tree damage vear-round in some areas

Localized in pheasant concentration areas

ingration

Migratory concentration REATING CONFLICT

Habitat loss to highway, farm, urban, and water project development; lack of management, range overuse, under-harvest

CONTROL METHODS

Fencing, repellents, alam devices, capture and transplant, shooting permits, hunter harvest

Habitat change by inten-

Fencing, repellents, shooting permits, range improvements, livestock reallocation, hunter harvest

Repellents, scare devices, special hunts, increased hunter harvest

Alarm devices, protective
Range loss to farm. water and urban project practices may intensify damage to young growth sifying agriculture

Change in native habitat and increased single-crop farming development; forestry nets, repellents, crop rotation, poisoning

Widespread seasonal attacks in migratory concentration areas

Favorable cover but lack natural food in proximity to agricultural crops

Alarm devices, protective nets, repellents, crop rotation, poisoning

Heavy feeding by huge Replacement of natura flocks; pulling of and pasture use by coots

food in concentration areas by extensive farm ing of attractive crops

Localized killing of lambs Coincidence of lambing by migrating eagles. with migratory eagles

Exploders, scare devices, fireworks, aerial herding. refuges as alternate feeding areas, hunting pressure, special hunts

Closer watch at lambing time in areas prone to eagle attack tack by resident animals on any available food source

Expansion of animal range, adaptability, and ability to eat almost Livetrapping, night hunting anything

Seasonal with crop pattern and lack of natural food; fluctuates with population cycles

Lack of effective population control methods, in creased agricultural plant ings, and suburban developments

Damage to field crops may be heavy and widewith species such as meadow mice; residen year-round problems

Bank burrowing may lead to washouts, flooding. bank erosion, debris clogging water structures

Resident, nocturnal predation on birds and poultry; odors from residence under buildings

Forest damage most severe in young trees; costly damage to buildings, equipment, and trail signs; quill injury to grazing cattle and horses

Migration into new irrig: tion areas; pond building may be beneficial or detrimental to fish habitat depending upon fish species and pond site

Agricultural crop and rangeland offers favorable habitat; rodent productivity high

Year-round activity; over population by lack of fur trappers

Repellents, fencing shooting and poisoning of jackrabbits

Repellents and screening for orchard tree and ornamental protection: trapping, fumigation, shooting; poisoning in organized control programs

Habitat control (vegetation removal by flooding); fur trapping; traps. poison in bait boxes

Suburban development in skunk habitat; skunks are a primary rabies carrier, and undesirable because of odor

Migration and over wintering may concentrate damage

Road and canal building. summer home and orchard development nea beaver waters; underharvest
Local predation yearround; rabies transmis sion to dogs; game bird predation not generally decisive population factor
Suburban development; lack of sport hunting, fur trapping poultry protection: traps shooting, fur trapping
Fencing and building for

Live traps, screening, trapping and shooting organized control in suburban prevention programs

Screening ornamenta plants; trapping and shooting; poison at dens roost trees, and travel routes

Livetrap and transplant; fencing; fur trapping. shooting in damage areas

Resident, year-round damage to poultry and
Range poultry and sheep operations offer available
Sport hunting, traps, shooting 


\begin{tabular}{|c|c|c|c|c|}
\hline BEAVER & $\begin{array}{l}\text { Tree cutting: riparian } \\
\text { softwoods, orchard, and } \\
\text { ornamentals, dam build- } \\
\text { ing may obstruct water } \\
\text { structures, flood roads } \\
\text { and meadows, create } \\
\text { washout hazards, affect } \\
\text { fish habitat }\end{array}$ & $\begin{array}{l}\text { Migration into new irriga- } \\
\text { tion areas; pond building } \\
\text { may be beneficial or det- } \\
\text { rimental to fish habitat } \\
\text { depending upon fish } \\
\text { species and pond site }\end{array}$ & $\begin{array}{l}\text { Road and canal building, } \\
\text { summer home and or- } \\
\text { chard development near } \\
\text { beaver waters; under- } \\
\text { harvest }\end{array}$ & $\begin{array}{l}\text { Livetrap and transplant; } \\
\text { fencing; fur trapping, } \\
\text { shooting in damage areas }\end{array}$ \\
\hline FOXES & $\begin{array}{l}\text { Poultry and game bird } \\
\text { depredation; rabies car- } \\
\text { rier }\end{array}$ & $\begin{array}{l}\text { Local predation year- } \\
\text { round; rabies transmis- } \\
\text { sion to dogs; game bird } \\
\text { predation not generally } \\
\text { decisive population factor }\end{array}$ & $\begin{array}{l}\text { Suburban development: } \\
\text { lack of sport hunting, fur } \\
\text { trapping }\end{array}$ & $\begin{array}{l}\text { Fencing and building for } \\
\text { poultry protection; traps, } \\
\text { shooting, fur trapping }\end{array}$ \\
\hline BOBCAT & $\begin{array}{l}\text { Depredation on birds, } \\
\text { poultry, lambs; rabies } \\
\text { carrier }\end{array}$ & $\begin{array}{l}\text { Resident, year-round } \\
\text { damage to poultry and } \\
\text { livestock; may be locally } \\
\text { important in game bird } \\
\text { introductions }\end{array}$ & $\begin{array}{l}\text { Range poultry and sheep } \\
\text { operations offer available } \\
\text { food }\end{array}$ & $\begin{array}{l}\text { Sport hunting, traps, } \\
\text { shooting }\end{array}$ \\
\hline COYOTE & $\begin{array}{l}\text { Sheep, goat and game } \\
\text { depredations; some crop } \\
\text { damage; public health } \\
\text { hazard }\end{array}$ & $\begin{array}{l}\text { Seasonal migration may } \\
\text { spread damage over wide } \\
\text { area; local losses of deer, } \\
\text { sheep, and poultry; } \\
\text { melon and fruit crops } \\
\text { may be damaged; rabies } \\
\text { transmission to dogs }\end{array}$ & $\begin{array}{l}\text { Agricultural and subur- } \\
\text { ban growth may provide } \\
\text { favorable habitat; coyote } \\
\text { adaptability }\end{array}$ & $\begin{array}{l}\text { Fencing, traps, shooting, } \\
\text { poison in supervised con- } \\
\text { trol programs }\end{array}$ \\
\hline MOUNTAIN LION & $\begin{array}{l}\text { Livestock and game } \\
\text { depredation }\end{array}$ & $\begin{array}{l}\text { Individuals may cause } \\
\text { local losses to sheep, } \\
\text { calves, colts, and deer }\end{array}$ & Mountain lions protected & $\begin{array}{l}\text { Sport hunting, traps and } \\
\text { dog hunting for depreda- } \\
\text { tion control }\end{array}$ \\
\hline BLACK BEAR & $\begin{array}{l}\text { Livestock killing; beehive, } \\
\text { cabin, and forest tree } \\
\text { damage; camp nuisance } \\
\text { and safety threat }\end{array}$ & $\begin{array}{l}\text { Individual bears may re- } \\
\text { quire control }\end{array}$ & $\begin{array}{l}\text { Inadequate natural food; } \\
\text { habitat change and in- } \\
\text { creased human activities } \\
\text { create conflict }\end{array}$ & $\begin{array}{l}\text { Sport hunting, liverrap } \\
\text { and transplant; traps and } \\
\text { dog hunting for damage } \\
\text { control or adjustment of } \\
\text { conflicting uses }\end{array}$ \\
\hline
\end{tabular}

"This table presents only a few representative examples of animal damage, possible causative factors, and suggested controls. Each damage pattern varies by area and with individual animal behavior. 
Project Co-ordinator: Sandy Behnke

4-H Branch,

Alberta Agriculture

Writer: Cheryl Clarke

Graphic Designer: Bobby Mok

Editorial Committee: Douglas F. Culbert

Fish and Wildlife Division,

Alberta Energy and Natural Resources

Lyle Lester,

Fish and Wildlife Division,

Alberta Energy and Natural Resources

Dave Mcyles,

Fish and Wildlife Division,

Alberta Energy and Natural Resources

Leonard J. Shandruk,

Canadian Wildlife Service,

Environment Canada 


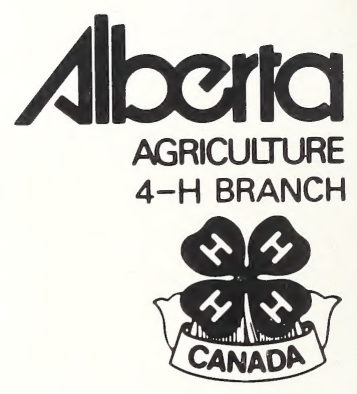

Environnement Canada Environment Canada

Service canadien de la faune

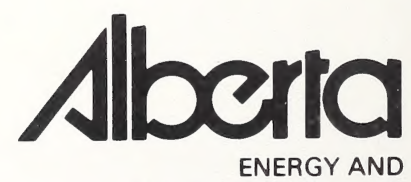

NATURAL RESOURCES

Fish and Wildlife Division 